\title{
Bibliografia historii wychowania, szkolnictwa i myśli pedagogicznej w Polsce za rok 2009 (z uzupelnieniami za lata poprzednie)
}

\begin{abstract}
Wstęp
Bibliografia obejmuje druki zwarte, artykuły z czasopism i prac zbiorowych, wydane w roku 2009 oraz pozycje z lat wcześniejszych, które nie zostały zarejestrowane w poprzednich częściach bibliografii, publikowanych na łamach Biuletynu Historii Wychowania od 2002 r. Nie uwzględniono recenzji opublikowanych w 2009 r., a dotyczących pozycji zarejestrowanych we wcześniejszych częściach bibliografii. Bibliografia ma układ według podanego niżej schematu. W poszczególnych działach i poddziałach (z wyjątkiem poddziału 5. Szkoły wyższe w Dziale III, gdzie zastosowano układ według nazw szkół oraz poddziału 2. Poszczególne biografie w Dziale IV, w którym pozycje ułożone zostały według nazwisk osób) zastosowano układ alfabetyczny według haseł autorskich lub tytułowych. Opisy w razie potrzeby zostały uzupełnione adnotacjami, a w przypadku prac zbiorowych wyszczególniono składające się na nie artykuły, dotyczące historii oświaty i wychowania.
\end{abstract}

Schemat układu bibliografii:

I. Opracowania ogólne. Bibliografie

II. Rozwój oświaty, wychowania i myśli pedagogicznej

1. Opracowania ogólne

2. Okres do 1795 roku

3. Okres $1795-1918$

4. Okres 1918-1939

5. Okres 1939-1945

6. Okres $1945-1989$

7. Okres 1989-2009

8. Oświata polonijna

III. Dzieje szkół różnych stopni

1. Szkoły podstawowe i zakłady wychowawcze

2. Szkoły średnie ogólnokształcące

3. Szkoły zawodowe

4. Zakłady kształcenia nauczycieli (z wyjątkiem szkół wyższych)

5. Szkoły wyższe

IV. Biografie

1. Zbiory życiorysów

2. Poszczególne biografie

V. Dzieje oświaty pozaszkolnej

1. Oświata dorosłych 
2. Biblioteki

VI. Dzieje ruchu nauczycielskiego

1. Opracowania ogólne

2. Pamiętniki nauczycieli

VII. Organizacje młodzieżowe

1. Harcerstwo

2. Inne 


\section{OPRACOWANIA OGÓLNE. BIBLIOGRAFIE}

1. AUSZ Mariusz: Międzynarodowa konferencja naukowa „Szkolnictwo pijarskie w czasach minionych a współczesne problemy edukacji historycznej" - Kazimierz Dolny 15-17 X 2007. Res Historica. T. 26: 2008 s. 191-193.

2. BARTOSZ Adam: Muzeum Lalek w Pilźnie - miniaturowy skansen. Lud. T. 93: 2009 s. $269-272$.

3. BĄK Aneta: Muzeum Zabawek i Zabawy - Kielce. Biuletyn Historii Wychowania. [Nr] 24: 2008 [dr.:] 2009 s. 165-168, sum.

Zał. w 1979 r.

4. BIBLIOGRAFIA historii wychowania, szkolnictwa i myśli pedagogicznej w Polsce za rok 2006 (z uzupełnieniami za lata poprzednie). Oprac. Anna Gruca. Biuletyn Historii Wychowania. [Nr] 24: 2008 [dr.:] 2009 s. 197-252.

5. BIDWEL A. Sybilla: „Abyś miał przekonanie, że jesteś najbardziej pożyteczny w tym, co robisz zarówno w nauce, jak i na Uniwersytecie". Prof. Władysław Czapliński o postawie uczonego w czasach PRL. Śląski Kwartalnik Historyczny Sobótka. R. 65: 2009 nr 2/3 s. 619-626.

6. BRYŁKA Agata: Sprawozdanie z VIII Katowickiej Konferencji Naukowej pt. „W 40-lecie powstania Uniwersytetu Śląskiego - szkolnictwo i nauka na Górnym Śląsku”, Katowice, 17-19 IX 2008 r. Śląski Kwartalnik Historyczny Sobótka. R. 65: 2009 nr 1 s. 105-107.

7. CICHOSZ Mariusz: Pedagogika społeczna w Polsce w latach 1945-2005. Rozwój, obszary refleksji i badań, koncepcje. Torun 2009 Adam Marszałek ss. 294, nlb. 1.

8. DOROBEK naukowy Prof. zw. dr hab. Danuty Koźmian. Oprac. Ilona Kość, Elżbieta Magiera. [W:] Z dziejów oświaty polskiej. Księga Jubileuszowa dedykowana Profesor Danucie Koźmian. Szczecin 2007 s. 19-30.

Z 1. 1972-2007.

9. DZIEJE pewnych zabawek. The history of some toys. Red. Agnieszka Kozłowska-Piasta; tł. Magdalena Moryc. Kielce 2009 Muzeum Zabawek i Zabawy ss. 286, nlb. 2, il.

Tekst równol. pol., ang.

Treść: Podsiadło Jolanta: Od zabawek do muzeum s. 9-21; Bąk Aneta, Myśliwiec Anna: Dzieje pewnego muzeum s. 23-62; Zięzio Ryszard: Moje tragikomiczne życie wśród zabawek s. 63-73; Bąk A.: Dzieje pewnych zabawek s. 75-79; Wzorcownia s. 81-110; Od narodu s. 11-138; Sąsiedzki dar s. 139-166; Zabawki z biwaku s. 167-178; Powiew Zachodu s. 179-190; W muzeum od niedawna s. 191-252; Z pól, łąk i wsi s. 253-280; Bibliografia s. 281-285.

10. FALKOWSKA Joanna: Seminarium naukowe nt. „Badania regionalne w polskiej historii wychowania" - Obrzycko 11-12 czerwca 2008 r. Biuletyn Historii Wychowania. [Nr] 24: 2008 [dr.:] 2009 s. 255-257.

11. FALKOWSKA J.: Sprawozdanie z obrad Sympozjum Historii Edukacji na XVIII Powszechnym Zjeździe Historyków Polskich w Olsztynie, 16-19 września 2009 roku. Acta Univiversitatis Nicolai Copernici. Nauki Humanistyczno-Społeczne. Z. 393: Pedagogika. [Nr] 25: 2009 s. $246-250$.

12. FIC Maciej: Quid libris utilius atque dulcius? Rozważania nad stanem badań chorzowskiego szkolnictwa. Zeszyty Chorzowskie. T. 10: 2009 s. 149-164, Zsfg. 
13. GŁOWACKA-SOBIECH Edyta: Badania regionalne w historii wychowania - problemy metodologiczne. Biuletyn Historii Wychowania. [Nr] 24: 2008 [dr.:] 2009 s. 7-21, sum.

14. GRZYBOWSKI ROMUALD: Pięćdziesięciolecie gdańskiej historii wychowania. Biuletyn Historii Wychowania. [Nr] 24: 2008 [dr.:] 2009 s. 139-164, sum.

15. GULCZYŃSKA Justyna: Ogólnopolska Konferencja Naukowo-Metodyczna pt.: „Między tradycją a współczesnością. W stronę aktywizujących metod nauczania historii wychowania" Gdańsk 1-2 grudnia 2008 r. Biuletyn Historii Wychowania. [Nr] 24: 2008 [dr.:] 2009 s. 260-261.

16. KLEMANTOWICZ Dariusz: Akta osobowe studentów jako źródło do badań naukowych. Archiwista Polski. R. 14: 2009 nr 1 s. 31-41, sum.

17. KWIECIŃSKI Zbigniew: Osobliwości opóźnień pedagogiki polskiej na początku lat dziewięćdziesiątych XX wieku. Ars Educandi. T. 5: 2008 s. 74-78, sum.

18. ŁAPOT Mirosław: Międzynarodowa konferencja: „Kulturowe uwarunkowania współczesnej edukacji”, Złoty Potok, 26-28 września 2008 roku. Przegląd Historyczno-Oświatowy. R. 52: 2009 nr $1 / 2$ s. $243-245$.

19. MARCINKOWSKI Piotr: Rola bibliotek cyfrowych w badaniach regionalnych. Biuletyn Historii Wychowania. [Nr] 24: 2008 [dr.:] 2009 s. 99-106, sum.

W historii edukacji i wychowania.

20. ORIENTACJE i kierunki w badaniach historyczno-pedagogicznych. Pod red. Iwonny Michalskiej i Grzegorza Michalskiego. Łódź 2009 Wydaw. Uniw. Łódzkiego ss. 268, il.

Treść: Michalski G.: Wstęp. 7-12; Cz. 1: Z problemów historii myśli pedagogicznej: Winiarz Adam: Geneza i rozwój zainteresowań zdrowiem uczniów w kręgu pedagogiki europejskiej s. 15-28; Leżańska Wiesława: Pedagogika małego dziecka w polskim Oświeceniu s. 28-40;

Jakubiak Krzysztof: Charakter narodowy Polaków i jego konsekwencje wychowawcze w świetle polskiego piśmiennictwa z końca XIX i początków XX wieku s. 41-49; Koźmian Danuta: Pedagogika niemiecka i jej recepcja w polskiej myśli pedagogicznej Drugiej Rzeczypospolitej (1918-1939) s. 50-54; Zalewska-Pawlak Mirosława: Historyczność jako zasada badań nad edukacją estetyczną s. 55-61; Cz. 2: Z dziejów szkolnictwa i upowszechniania oświaty: Żołądź-Strzelczyk Dorota: Stan szkolnictwa parafialnego w Wielkopolsce w XVI-XVIII wieku (od czasów reform Komisji Edukacji Narodowej) s. 65-77; Ryś Jan: Korpus Kadetów GrodzieńskoWileński na tle szkolnictwa wojskowego w Polsce w II połowie XVIII w. s. 78-86; Kicowska Alicja: Tradycje ludowej szkoły rolniczej źródłem inspiracji w poszukiwaniu modelu współczesnej szkoły rolniczej s. 87-92; Ślęczka Ryszard: Szkolnictwo dokształcające w Krakowie w latach 1918-1951; Wira-Świątkowska Katarzyna: Przemiany w zakresie organizacji instytucji wychowania przedszkolnego w okresie II Rzeczypospolitej s. 101-112; Sapia-Drewniak Eleonora: Przebieg akcji likwidacji analfabetyzmu na Opolszczyźnie po II wojnie światowej s. 113-122; Grzybowski Romuald: Pedagogizacja rodziny jako próba włączenia jej do procesu laicyzacji wychowania dzieci i młodzieży w PRL s. 123-137; Gumuła Teresa: Poszukiwanie optymalnego modelu edukacji nauczycielskiej s. 138-151; Cz. 3: Ludzie i instytucje na rzecz szkoły, wychowania i kultury: Mokrzecki Lech: Andrzej Franckenberger autor pierwszego statutu Gimnazjum Gdańskiego z roku 1568 s. 155-163; Dybiec Julian: Profesorskie dyskusje nad podręcznikiem dla szkół elementarnych w Wolnym Mieście Krakowie s. 164-174; Poznański Karol: Rola [Gawriła] Dukszty-Dukszyńskiego w kreowaniu polityki oświatowej w Królestwie Polskim w epoce paskiewiczowskiej s. 175-186; Wnęk Jan: Problemy edukacyjne w „Liście do matki troskliwej” Ignacego Benedykta Rakowieckiego s. 187-201; Witkowska-Urban Ewa: Seweryna Pruszakowa jako literatka i redaktorka pisma dla młodzieży s. 202-213; Szulakiewicz Władysława: „Lwów dziennikarski” we wspomnieniach Stanisława Lempickiego s. 214-224; Michalska I.: Literatura marynistyczna w służbie wychowania młodego pokolenia Polaków w okresie międzywojennym s. 225-236; Walasek Stefania: Aktywność edukacyjna polskiego społeczeństwa w XIX i XX wieku s. 237-245; Szymczak Kinga: Wydawnictwa Towarzystwa Nauczycieli Szkół Wyższych w latach 1884-1916 s. 246-254; Michalski G.: Problemy nauczania religii w szkołach Drugiej Rzeczypospolitej na łamach „Miesięcznika Katechetycznego i Wychowawczego" s. 255-268. 
21. PACZYŃSKA Irena: Krakowski ośrodek dokumentacji dziejów tajnej oświaty (1958-1993). [W:] Społeczeństwo, kultura, inteligencja. Studia historyczne ofiarowane Profesor Irenie Homoli-Skąpskiej. Pod red. Elżbiety Orman i Grzegorza Niecia. Kraków-Warszawa 2009 s. $473-493$.

22. RODZIEWICZ Ewa: Ku demokracji w sferze publicznej i dyskursie edukacyjnym. Polskie Towarzystwo Pedagogiczne Oddział w Gdańsku wobec zmiany społecznej. Ars Educandi. T. 5: 2008 s. $11-59$, sum.

23. SMOŁALSKI Antoni: Szkoła a państwo, Kościół i społeczeństwo w polskiej nowożytnej myśli pedagogicznej. Przegląd Historyczno-Oświatowy. R. 52: 2009 nr 1/2 s. 5-18.

XVI-XX w.

24. STĘPKOWSKI Dariusz: Polska bibliografia Herbarta (do roku 2007). Przeglad Historyczno-Oświatowy. R. 52: 2009 nr 1/2 s. 142-153.

Johann Friedrich Herbart (1776-1841).

25. WASIELEWSKI Krzysztof: Sprawozdanie z konferencji „Zmiany w edukacji - próba bilansu. Kryteria oświatowe, społeczne i ludzkie”. Wieś i Rolnictwo. 2009 nr 3 s. 158-162.

Toruń, 27-28 V 2009 r.

\section{ROZWÓJ OŚWIATY, WYCHOWANIA I MYŚLI PEDAGOGICZNEJ}

\section{Opracowania ogólne}

26. BANACH Andrzej K[azimierz]: Kariery zawodowe studentów Uniwersytetu Jagiellońskiego pochodzenia chłopskiego z lat 1860/1861-1917/1918. Kraków 2009 Księg. Akademicka ss. 488, tabl. 4, il., sum., Zsfg.

27. BARZYCKI Andrzej: Bracia doloryści i ich działalność oświatowa w Zawichoście. Studia Sandomierskie. T. 16: 2009 z. 1/2 s. 159-168, rias.

Lata $1893-1948$.

28. BŁASZCZYK Tomasz: Konwikty dla ubogich uczniów na Śląsku. Saeculum Christianum. R. 14: 2007 nr 1 s. 109-119, Zsfg.

XVI-XX w.

29. CUKRAS-STELĄGOWSKA Joanna: Żydowskie szkoły świeckie - pomiędzy tradycją a nowoczesnością. Acta Universitatis Nicolai Copernici. Nauki Humanistyczno-Społeczne. Z. 393: Pedagogika. [Nr] 25: 2009 s. 95-108.

Lata $1915-1968$.

30. CURYL Zbigniew: Nasz Dom. Dzieje młodzieżowego Domu Kultury w Świdnicy. Cz. 1. (Lata 1951-1997). Rocznik Świdnicki. T. 36: 2008 [dr.:] 2009 s. 99-121.

31. CZAPLINEK 1945-2009. Cz. 1: Historia powrotu do macierzy. Red. Brunon Bronk [i in.]. Wyd. 2 uzup. i rozsz. Czaplinek 2009 Stow. Przyj. Czaplinka ss. 233, il.

Z treści: Zarys historii oświaty: Żwirko Janina: Przedszkola s. 56-58; Szkoły podstawowe i gimnazjum. [Aut.] B. Bronk [i in.] s. 59-90; Połoński Andrzej, Cylkowska Violetta, Sapiński Andrzej: Szkoły ponadgimnazjalne s. 90-108; Noty biograficzne. [Aut.] Wiesław Krzywicki [i in.] s. 109-219.

Wyd. 1 cz. 1 pt. Czaplinek 1945-2005. 60-ta rocznica powrotu do Macierzy. Czaplinek 2005. 
32. DA na Miasteczku 1958-2008. 50 lat Duszpasterstwa Akademickiego na Miasteczku przy parafii p.w. NMP z Lourdes Zgromadzenia Księży Misjonarzy w Krakowie. Księga jubileuszowa. Oprac. i red. Tekstu Antoni Miciak, Ryszard Oleszkowicz. Kraków 2009 Poligrafia Inspektoratu Tow. Salezjańskiego ss. 376, il.

Treść: Geneza: Duszpasterstwo akademickie w Krakowie od zarania do połowy XX w. s. 21-27; Parafia NMP z Lourdes w Krakowie w okresie przed- i powojennym s. 27-30; Działania WUBP w Krakowie przeciwko środowiskom duszpasterstw akademickich Krakowa w latach 1954-1957 s. 30-43; Powstanie Duszpasterstwa Akademickiego na Miasteczku i pierwsza dekada działalności (1958-1968): Powstanie DA przy parafii NMP z Lourdes - 5 X 1958 r. s. 45-49; Formy działalności i ważniejsze wydarzenia pierwszej dekady, 1958-1968 s. 50-61; Aktywizacja SB wobec krakowskich duszpasterstw akademickich - Sprawa Obiektowa „Wierni” (1961-1968) s. 62-75; Powstanie kolejnych krakowskich duszpasterstw akademickich s. 75-78; Duszpasterze pierwszej dekady s. 78-79; Druga dekada (1968-1978): Lata kontestacji s. 81-84; Formy działalności i ważniejsze wydarzenia drugiej dekady, 1968-1978 s. 84-103; Działania SB przeciwko krakowskiemu środowisku studenckiemu i duszpasterstwom akademickim (1968-1978) s. 103-106; Duszpasterze drugiej dekady s. 107; „Dwudziestka” s. 108-111; Trzecia dekada (1978-1988): „Habemus Papam!” s. 113-116; Zamach na Jana Pawła II i „Biały Marsz” w maju 1981 r., Pierwsza Piesza Pielgrzymka Krakowska na Jasną Górę s. 117-121; Inicjatywy duszpasterskie, formy i metody pracy DA na Miasteczku w trzeciej dekadzie, 1978-1988 s. 122-142; SB wobec wyboru K. Wojtyły na papieża i aktywności duszpasterstw akademickich (1978-1989) s. 142-145; DA na Miasteczku w drugiej połowie lat 80-tych XX w. s. 145-155; Duszpasterze trzeciej dekady s. 156-157; Czwarta dekada (1988-1998): Zmiany w Polsce w latach 1988-1990 s. 159-160; Reaktywowanie Stowarzyszenia Młodzieży Akademickiej w Krakowie (1988) s. 160-161; Formy działalności i ważniejsze wydarzenia czwartej dekady w DA na Miasteczku, 1988-1993 s. 161-177; Duszpasterskie małżeństwa i „diakonia prowadzenia wesel" w DA na Miasteczku s. 178-181; Formy działalności i ważniejsze wydarzenia czwartej dekady w DA na Miasteczku, 1993-1998 s. 182-187; Muzyka i śpiew w DA s. 187-194; Duszpasterze czwartej dekady s. 195-197; Kronika DA na Miasteczku - 2. połowa 1997 r. s. 198-199; Na przełomie tysiącleci piąta dekada (1998-2008): W kierunku odrodzenia DA na Miasteczku s. 201-206; Kronika DA na Miasteczku, 1998-2007 s. 206-324; Duszpasterze piątej dekady s. 324-325; Duszpasterstwo Akademickie na Miasteczku w roku 2008: Kronika działalności w 2008 r. s. 327-339; Formy i metody pracy w 2008 r. s. 339-344; Zamiast zakończenia s. 345-346; Aneksy: Duszpasterze akademiccy w DA na Miasteczku 1958-2008, Liderzy wspólnot - od 1996 r., Małżeństwa duszpasterskie (fragmenty listów), Duszpasterstwa akademickie archidiecezji krakowskiej - 2007/2008, Modlitwy w różnych, studenckich, sytuacjach życiowych s. 347-358.

33. DALECKI Maciej: Wystawa „Archiwalia szkół z 2. połowy XIX w. i 1. połowy XX w. w zbiorach Archiwum Państwowego w Przemyślu. Rocznik Historyczno-Archiwalny. T. 20: 2007/2008 [dr.:] 2009 s. 265-266.

6-25 IX $2006 \mathrm{r}$.

34. DIAKOWSKI Antoni: Oławska oświata w latach 1945-2005. Oława 2009 Stow. Pomost - Sojusz dla Oławy i Ziemi Oławskiej ss. 90, il. (Diamentowa Seria).

35. DOMAŃSKI Cezary W.: Psychologowie i psychiatrzy polscy na studiach na Uniwersytecie w Zurychu do 1939 roku. [W:] Psychologia europejska w okresie międzywojennym. Pod red. nauk. Włodzimierza Zeidlera. Warszawa 2009 s. 77-86.

36. GERLIC Henryk: Szkoły cysterskie w Rudach. [W:] Cystersi w Rudach. Red. Franciszek Wolnik. Opole 2009 s. 113-146.

37. GLIŃSKI Waldemar: Kształtowanie się sieci diecezjalnych seminariów duchownych w okresie staropolskim oraz na przełomie XVIII i XIX w. Saeculum Christianum. R. 14: 2007 nr 2 s. $129-146$, riass.

Od XVI w.

38. GŁOWACKA-GRAJPER Małgorzata: Mniejszościowe grupy etniczne w systemie szkolnictwa w Polsce. Przekaz kulturowy a więź etniczna. Warszawa 2009 Wydaw. Uniw. Warszawskiego ss. 312. Inst. Socjologii Uniw. Warszawskiego.

Po II wojnie światowej. 
39. KALITTA Emilia: Towarzystwo Przyjaciół Dzieci działa od 90 lat. Chojnice 2009 Logo; na zlec. Tow. Przyj. Dzieci ss. 48, il. (Biblioteka Filomaty; t. 15).

40. KAŁUŻNY Ryszard: Wyższe szkoły oficerskie wojsk lądowych w Polsce w latach 1967-1997. Zielona Góra 2005 Oficyna Wydawnicza Uniw. Zielonogórskiego ss. 349.

41. KURIAŃSKI Mieczysław: Ku poszerzeniu horyzontów polskiej szkoły. Szkic historyczny edukacji. Zagrożenia i szanse. Saeculum Christianum. R. 15: 2008 nr 1 s. 193-221, sum.

42. MAJKA Roman: Działalność wychowawcza i edukacyjna księży Michalitów jako pomoc państwu polskiemu (w świetle zasobu Archiwum Generalnego Zgromadzenia św. Michała Archanioła) - (komunikat). [W:] Kościół i państwo w dziejach, źródłach i studiach nad przeszłością. Red. nauk. Marek Stawski. Warszawa 2008 s. 61-70.

43. MOLENDOWSKI Leszek: Dzieje Ojców Jezuitów i szkolnictwa jezuickiego w Gdyni. Kraków 2009 Avalon T. Janowski ss. 304, tabl. 16, il.

XX-XXI w.

44. MOZAIKA powiatu pińczowskiego. T. 9. Pod red. Andrzeja Kozery. Kielce 2009 Zakł. Poligraficzno-Wydawniczy U Poety ss. 209, il.

Z treści: Sprawozdanie z 10-letniej pracy Zespołu Szkół Ponadgimnazjalnych w Działoszycach s. 74-91; Nowak Tomasz: Tradycje oświatowe szkoły w Sędowicach s. 92-103; Zespół Szkół Zawodowych w Pińczowie s. $117-130$.

45. Od AKADEMII Lubrańskiego do Wydziału Teologicznego Uniwersytetu im. Adama Mickiewicza. Tradycja wyższych studiów teologicznych w Poznaniu. Red. Jan Szpet. Poznań 2009 UAM. Wydz. Teol. Red. Wydawnictw ss. 177, nlb. 1, il.

Z treści: Szpet J.: Tradycja wyższych studiów teologicznych w Poznaniu. W 40-lecie powołania Papieskiego Wydziału Teologicznego i 10-lecie Wydziału Teologicznego UAM s. 11-16; Gądecki Stanisław: „Pamiętaj na wszystkie drogi”. 40-lecie Papieskiego Wydziału Teologicznego w Poznaniu, 10-lecie Wydziału Teologicznego UAM s. 17-39; Witkowski Rafał: Teologia w murach Akademii Lubrańskiego i Kolegium Jezuitów w Poznaniu w XVI wieku i pierwszej połowie XVII wieku s. 61-76; Czubiński Antoni: Wydział Teologiczny (w latach 1918-1922) s. 77-84; Dworacki Roman: Deus scientiarum dominus - Bóg panem nauk. 40-lecie powstania Wydziału Teologicznego w Poznaniu 1969-2009. Okres 1969-1998 s. 85-141; Przybecki Adam: Kościół w spotkaniu z uniwersytetem s. 161-178.

46. OLSZEWSKI Edward, Puka Agata: Studia politologiczne w Polsce. Polityka i Społeczeństwo. Nr 1: 2004 s. 39-80, sum.

Od XVI w.

47. OŚWIATA w Kurowie Lubelskim. Praca zbior. pod red. Krzysztofa Andrzeja Boreczka. Lublin-Kurów 2009 Urząd Gm.; Kurowskie Tow. Region. ss. 159, il.

Treść: Boreczek K. A.: W dobie Rzeczypospolitej szlacheckiej i Księstwa Warszawskiego s. 5-10; Robaczewska Teresa: Szkoła elementarna w latach 1815-1867 s. 11-40; Boreczek K. A.: W okresie intensywnej rusyfikacji i okupacji austriackiej s. 41-55; Michalik Jan: W latach II Rzeczypospolitej i okupacji niemieckiej s. 56-88; Żurkowska Hanna: Szkoła Podstawowa w drugiej połowie XX stulecia s. 89-136; Kopeć Henryk: Oświata rolnicza w gminie Kurów w latach 1958-1985 s. 137-147; Żurkowski Włodzimierz: Publiczne Gimnazjum nr 1 im. Ignacego Potockiego s. 148-157.

48. PER aspera ad astra. 65 rocznica powstania szkoły. Pod red. Mariana Żubera, Marka Kulczyckiego. Wrocław 2009 Wyższa Szkoła Oficerska Wojsk Lądowych im. gen. T. Kościuszki ss. nlb. 2, 76, il.

We Wrocławiu.

Z treści: Jaklewicz Kazimierz: Wyższa Szkoła Oficerska Wojsk Lądowych wczoraj i dziś s. 5-9; Brzeziński Stanisław: Utworzenie Oficerskiej Szkoły Piechoty i jej przekształcenia na przestrzeni dziesięcioleci s. 11-18; 
Cutter Zdzisław: Szkolnictwo saperskie Polskich Sił Zbrojnych na Zachodzie w latach drugiej wojny światowej s. 19-25; Kusiak Franciszek: Wychowanie i działalność kulturalna we wrocławskich uczelniach wojskowych po II wojnie światowej s. 27-33; Kałużny Ryszard: Wyższe szkoły oficerskie w okresie restrukturyzacji sił zbrojnych s. 35-46; Szelka Janusz: Nauka wczoraj i dziś wrocławskiej wyższej szkoły oficerskiej s. 47-61; Adamski Wojciech: Wyższa Szkoła Oficerska dla miasta - współpraca WSO z władzami miasta s. 63-71.

49. PRZESZŁOŚĆ i dzień dzisiejszy bytomskich szkół. Praca zbior. pod red. Łucji Bobek. Bytom 2009 TMB ss. 496, tabl. 16, il. Tow. Miłośn. Bytomia.

Z treści: [Cz. 1]. Początki i rozwój szkolnictwa w Bytomiu: Bobek Ł.: Szkolnictwo w Bytomiu do okresu międzywojennego s. 9-29; Lusek Joanna: Szkolnictwo w Bytomiu w okresie międzywojennym s. 30-48; Bobik Bogumiła: Szkolnictwo w Bytomiu w latach 1939-1945 s. 49-50; Bobik B.: Szkolnictwo w Bytomiu po II wojnie światowej s. 51-82; [Cz. 2]: Szkoły dawniej i dziś na tle historii dzielnic s. 83-487.

50. PUZIO Władysław: Dzieje szkolnictwa i oświaty w Raniżowie w latach 1604-2004. (Zarys monograficzny). Raniżow 2009 [B.w.] ss. 357, il.

51. RADOMSKI Grzegorz: Role religii w koncepcjach wychowawczych obozu narodowego do 1939 roku. Paedagogia Christiana. [Nr] 15: 2005 s. 75-87, Zsfg.

52. RĘDZIŃSKI Kazimierz: Szkoła Józefa Perla w Tarnopolu (1813-1939). [W:] Społeczne konteksty edukacji. Pod red. Kazimierza Rędzińskiego i Mirosława Łapota. Gliwice 2009 Wydaw. Gliwickiej Wyższej Szkoły Przedsiębiorczości s. 225-245.

53. SAPIA-DREWNIAK Eleonora, Piechnik-Borusowska Jolanta: Contribution of educational societies to the development of the European culture. Opole 2008 Wydaw. UO ss. 205.

Lata $1880-1939$.

Rec.: Frąckowiak Anna, Acta Universitatis Nicolai Copernici. Nauki Humanistyczno-Społeczne Z. 392: Pedagogika. [Nr] 24: 2009 s. 172-175.

54. SZKOLNICTWO w Ostrowie i okolicy. Pod red. Mariana Markiewicza. Ostrów Lubelski 2009 Bestprint ss. 336, il. Tow. Ziemi Ostrowa Lubelskiego.

Treść: Markiewicz M.: Wstęp s. 13-14; Markiewicz M.: Szkolnictwo ostrowskie do roku 1918 w kontekście historycznych uwarunkowań kraju s. 15-55; Kuszyk Stanisław: Tworzenie szkolnictwa polskiego w latach 1918-1944 s. 57-126; Czapska Beata: Szkolnictwo w Ostrowie Lubelskim s. 127-135; Czapska B.: Szkoła Podstawowa w Ostrowie Lubelskim w latach 1945-2008 s. 136-161; Góźdż Julita: Szkoła Podstawowa w Ostrowie Lubelskim w latach 2000-2008 s. 162-172; Czapska B.: Gimnazjum w Ostrowie Lubelskim s. 173-179; Czapska B.: Biblioteka Publiczna w Ostrowie Lubelskim s. 180-182; Czapska B.: Sylwetki niektórych nauczycieli s. 185-215; Frelich Aneta: Historia Szkół Rolniczych, Górniczych, Zespołu Szkół w Ostrowie Lubelskim w latach 1967-2008 s. 216-242; Czapska B.: Szkoła Podstawowa w Kolechowicach s. 243-255; Czapska B.: Historia Szkoły Podstawowej w Kaznowie s. 256-277; Czapska B.: Szkoła w Rozkopaczewie s. 278-288; Czapska B.: Biblioteka w Rozkopaczewie s. 289-292; Markiewicz M.: Szkoła w Bójkach s. 293-295; Kapitan Bolesław: Szkoła Podstawowa w Jamach s. 296-303; Kuszyk S.: Historia Szkoły Podstawowej w Jedlance Starej, Rudce Starościańskiej, Jedlance Nowej w latach 1920-2008 s. 304-330.

55. SZKOŁA państwo, społeczeństwo. Między autonomią a podległością. Konferencja Naukowa z Okazji 50-lecia Zakładu Historii Nauki, Oświaty i Wychowania, Gdańsk, dn. 23-25.09.2009 r. Oprac. Andrzej Kołakowski, Tomasz Maliszewski. Gdańsk 2009 Drukarnia Oruńska ss. 120. Zakł. Historii Nauki, Oświaty i Wychowania. Inst. Pedagogiki Uniw. Gdańskiego.

Streszczenia referatów.

56. SZTABA Radosław: Zakonne zakłady opieki nad dzieckiem we Lwowie w latach 1861-1939. Przeglad Historyczno-Oświatowy. R. 52: 2009 nr 3/4 s. 35-51.

57. SZYSZKA Bogdan: Mecenat oświatowy Zamoyskich 1784-1939. Zamość 2009 Abacus ss. 236, il.

Rec.: Doroszewski Jerzy, Przegląd Historyczno-Oświatowy. R. 52: 2009 3/4 s. 183-185. 
58. TCHÓRZ Roksana: Szkolnictwo ukraińskie na Warmii i Mazurach. Nowa Ukraina. 2007 z. $1 / 2$ s. $156-164$, rez., sum.

Od 1952 r.

59. TOWARZYSTWA społeczne i ich działalność oświatowa. Konteksty historyczne i teraźniejszość. Praca zbior. pod red. nauk. Eleonory Sapii-Drewniak. Dąbrowa Górnicza 2009 Wyższa Szkoła Biznesu ss. 249, sum. (Prace Naukowe Wyższej Szkoły Biznesu w Dąbrowie Górniczej).

Z treści: Wstęp s. 7-9; Jakubiak Krzysztof: Stowarzyszeniowy ruch rodzicielski w Europie Zachodniej i na ziemiach polskich w początkach XX wieku s. 13-21; Jamrożek Wiesław: Aktywność edukacyjna galicyjskiego Towarzystwa Uniwersytetu Ludowego im. Adama Mickiewicza s. 23-37; Karcz Eugenia: Inicjatywy oświatowe Polskiej Macierzy Szkolnej w Królestwie Polskim po 1905 roku s. 37-47; Nowak-Wolna Krystyna: Działalność oświatowa Związku Teatrów i Chórów Włościańskich we Lwowie s. 49-66; Stopińska-Pająk Agnieszka: Działalność i funkcje społeczno-edukacyjne Towarzystwa Przyjaciół Nauk na Śląsku s. 69-104; Sapia-Drewniak E.: Górnoślązacy w polskim ruchu akademickim we Wrocławiu w latach 1922-1939 s. 105-114; Gulczyńska Justyna: Rola Towarzystwa Czytelni Ludowych w procesie kształtowania tożsamości narodowej mieszkańców Wielkopolski w latach 1880-1939 oraz obecny jego charakter s. 115-126; Piwowarczyk Mirosław: Rola towarzystw kulturalno-oświatowych w kształtowaniu kulturowego charakteru środowiska lokalnego Gostynia w II Rzeczypospolitej s. 127-147; Szarkowska Agnieszka: Prywatne szkoły narodowo-hebrajskie Jabne i Tarbut jako przykład aktywnej działalności żydowskich stowarzyszeń i organizacji kulturalnooświatowych w województwie białostockim w II Rzeczypospolitej s. 149-152; Półturzycki Józef: Stowarzyszenia oświatowe w badaniach i koncepcji teoretycznej Aleksandra Kamińskiego s. 163-177; Szablicka-Żak: Aktywność działaczy oświatowych w Parlamencie II Rzeczypospolitej s. 179-191; Bernasiewicz Maciej, Kowalski Adrian: Stowarzyszenie Pomocy Dzieciom i Młodzieży „Dom Aniołów Stróżów” w Katowicach s. 195-204; Zieliński Jerzy, Herda Katarzyna: Stowarzyszenia działające na rzecz dzieci z ADHD s. 205-215; Piechnik-Borusowska Jolanta: Towarzystwo Rozwoju Rodziny i jego oświatowa i działalność związana z planowaniem rodziny s. 217-224.

60. URBANOWICZ Beata: Obchody Święta Niepodległości w częstochowskich placówkach oświatowych w latach 1918-2007. [W:] Tradycje 11 listopada w Częstochowie. Pod red. Ryszarda Szweda. Częstochowa 2008 s. 337-362.

61. W SŁUŻBIE historii nauki, kultury i edukacji. Księga pamiątkowa dedykowana prof. Lechowi Mokrzeckiemu z okazji jubileuszu pięćdziesięciolecia pracy zawodowej. Pod red. Romualda Grzybowskiego i Tomasza Maliszewskiego. Gdańsk 2008 Wydaw. Uniw. Gdańskiego ss. 488 , il.

Treść: Bartnicka Kalina: Jubileusz Profesora Lecha Mokrzeckiego - laudacja w Dworze Artusa w Gdańsku, czerwiec 2005 roku s. 13-16; Puchowski Kazimierz, Żerko Józef: Profesor Lech Marian Mokrzecki - badacz dziejów nauki, kultury i oświaty s. 17-24; Doktorzy promowani przez Profesora Lecha Mokrzeckiego. Oprac. Zofia Anikiej s. 25-26; Publikacje Profesora Lecha Mokrzeckiego (lata 1951-2006). Oprac. Tomasz Maliszewski s. 27-60; Dybiec Julian: Historia wychowania w postmodernistycznym świecie s. 63-71; Grzybkowski Romuald: Pedagogika bez przeszłości? Szkic do dziejów walki o należne miejsce historii wychowania w kształceniu pedagogów s. 72-91; Szulakiewicz Władysława: „Minerwa Polska” - czasopismo naukowe poświęcone historii oświaty i wychowania s. 92-104; Edmund Kotarski: Krajobraz medialny Heweliuszowego Gdańska s. 105-115; Brodnicki Mariusz: Kształtowanie się arystotelizmu niescholastycznego w siedemnastowiecznym Gdańsku s. 116-126; Pelczar Roman: Szkolnictwo ormiańskie w Rzeczypospolitej w XVI-XVIII wieku s. 127-139; Adamczyk Mieczysław: Węgrzy na ziemiach polskich w XVIII-XIX wieku s. 140-148; Krawczyk Antoni: Poglądy Johna Miltona (1608-1674) na edukację s. 149-158; Taraszkiewicz Jacek: Pijarskie „Ratio studiorum” s. 159-164; Ausz Mariusz: Pijarskie gymnasium artificum s. 165-171; Kochanowicz Jerzy: Zasady dotyczące kar cielesnych w pierwszych kolegiach jezuickich s. 172-183; Puchowski Kazimierz: Kształcenie elit w madryckim Real Seminario de Nobles (1727-1765) s. 184-195; Żołądź-Strzelczyk Dorota: Krytyka zagranicznych wojaży edukacyjnych młodzieży polskiej s. 196-201; Jakubiak Krzysztof: Relacje rodziny i szkoły w polskiej myśli pedagogicznej i praktyce edukacyjnej XIX i początków XX wieku s. 202-214; Winiarz Adam: Kwestia kobieca na ziemiach polskich w XIX wieku. Stan i potrzeby badań s. 215-234; Burzyńska-Wentland Lidia: Polscy studenci z Prus Zachodnich na studiach w uniwersytetach niemieckich $w$ drugiej połowie XIX i na początku XX wieku s. 235-242; Rędziński 
Kazimierz: Szkolnictwo polskie w Kijowie w latach 1914-1920; Szews Jerzy: Maria Ostrowska: szkic do portretu s. 259-260; Leżańska Wiesława: Edukacja obywatelska w seminariach nauczycielskich II Rzeczypospolitej s. 261-269; Maliszewski T.: Uniwersytet Ludowy w Michałówce (1932-1939) - szkic z historii oświaty i kultury pogranicza s. 270-279; Zaniewska Teresa: Polskie Liceum w Szwajcarii OberburgWetzikon (1940-1944) s. 280-293; Pawelski Leszek: Z dziejów gimnazjum szczecineckiego okresu niemieckiego s. 294-302; Maliszewski Kazimierz: Rola i znaczenie działalności Duszpasterstwa Akademickiego OO. Jezuitów w środowisku uniwersyteckim Torunia w latach 1963-1988 s. 303-311; Żerko Józef: Z dziejów współpracy Uniwersytetu Gdańskiego z Uniwersytetem w Linkňpingu (1984-2004) s. 312-320; Uchyła-Zroski Jadwiga: Od rogu naturalnego do muzyki myśliwskiej - ważność tradycji we współczesności s. 321-331; Michalski Andrzej: Szkic do przemian ustrojowych szkolnictwa muzycznego w okresie II Rzeczypospolitej Polskiej s. 332-343; Machel Henryk: Resocjalizacja penitencjarna - rozwój idei s. 344-356; Barczyk Piotr B.: Z przeszłości polskiej penicjarystyki (1918-1928) s. 357-363; Porożyński Henryk: Wielokulturowość wyzwaniem dla współczesnej polskiej edukacji. Stan i perspektywa badań s. 364-369; Siwoszko Janina: Szkolnictwo prywatne w Polsce i Szwecji s. 370-380; Z piórem i muzyką przez życie. Profesor Lech Mokrzecki. Rozmowy z Jubilatem. Rozmawia T. Maliszewski s. 385-482.

Toż. Wyd. 2 popr. i uzup. Gdańsk 2008 Wydaw. Uniw. Gdańskiego; Fund. Rozwoju Uniw. Gdańskiego ss. 497, il.

Rec. [Wyd. 2]: Wałęga Agnieszka, Biuletyn Historii Wychowania. [Nr] 24: 2008 [dr.:] 2009 s. 186-189.

62. WAŁĘGA Agnieszka: Autorzy polskich podręczników do historii wychowania XIX i I połowy XX wieku. Acta Universitatis. Nicolai Copernici. Nauki Humanistyczno-Społeczne Z. 392: Pedagogika. [Nr] 24: 2009 s. 95-116.

63. WESOŁOWSKA Sylwia: Z dziejów szkolnictwa w Gminie i Mieście Sianów do 1945 roku. [W:] Historia i kultura Ziemi Sławieńskiej. T. 8: Gmina i miasto Sianów. Red. Włodzimierz Rączkowski, Jan Sroka. Sianów-Sławno 2009 s. 177-207.

64. Z DZIEJÓW oświaty polskiej. Księga Jubileuszowa dedykowana Profesor Danucie Koźmian. Pod red. Ilony Kość i Elżbiety Magiery. Szczecin 2007 Wydaw. Nauk. US ss. 372 , nlb. 11, il., sum. Uniw. Szczeciński. (Rozprawy i Studia; t. (746) 672).

Z okazji 70-lecia urodzin, 27 IV $2006 \mathrm{r}$.

Z treści: Kość I., Magiera E.: Słowo wstępne s. 11-12; Jankowski Robert: Profesor Danuta Koźmian Uczona i Mistrz dla kilku pokoleń nauczycieli na Pomorzu Zachodnim s. 13-18; Cz. 1: Metodologiczne problemy historii wychowania: Jakubiak Krzysztof, Jamrożek Wiesław: Tematyka i źródła w polskich badaniach nad dziejami wychowania (zarys problemu) s. 45-54; Jałmużna Tadeusz, Wiśniewska Ewa: Regionalne badania pedeutologiczne s. 55-69; Król Joanna: Potrzeba badań regionalnych - spojrzenie historyka oświaty s. 71-82; Cz. 2: Z dziejów oświaty na przełomie XIX/XX wieku i w Drugiej Rzeczypospolitej: Szulakiewicz Władysława: Pamiętnikarski portret nauczycieli w ujęciu Rafała Taubenschlaga (1881-1958) s. 85-95; Michalski Grzegorz: Początki i kształtowanie się związków nauczycielskich w Łodzi s. 97-111; Michalska Iwonna: Działalność ministerialnej komisji selekcji piśmiennictwa dla dzieci i młodzieży w okresie międzywojennym s. 113-123; Magiera E.: Prasa młodzieżowa Drugiej Rzeczypospolitej jako miejsce popularyzowania wychowania państwowego s. 125-143; Sapia-Drewniak Eleonora: Znaczenie Polsko-Katolickiego Towarzystwa Szkolnego na Śląsku Opolskim w rozbudzaniu potrzeb edukacyjnych i kulturalnych ludności w okresie międzywojennym s. 145-157; Walasek Stefania: Prace wileńskiego Towarzystwa Oświatowego „Światło” na rzecz kształcenia zawodowego dzieci i młodzieży w II Rzeczypospolitej s. 159-166; Wilczyński Zenon: Formy oświaty pozaszkolnej na Pomorzu i ich rozwój w okresie międzywojennym s. 167-180; Cz. 3: Teoria i praktyka edukacyjna w drugiej połowie XX wieku: Kozłowski Kazimierz: Miejsce Arcybiskupa ks. Profesora Kazimierza Majdańskiego w najnowszych dziejach Pomorza Zachodniego s. 183-192; Turek-Kwiatkowska Lucyna: Specyfika oświaty szczecińskiej s. 193-200; Kicowska Alicja: Szkic do biografii zbiorowej nauczycieli szkół rolniczych na Warmii i Mazurach (1945-1989) s. 201-209; Walak Bogumiła: Dziedziny aktywności społecznej nauczycieli szkół podstawowych na ziemi gorzowskiej w okresie pionierskim s. 211-222; Grzybowski Romuald: Działalność wychowawcza i ideowo-polityczna prowadzona w liceach pedagogicznych w województwie gdańskim (1945-1970) s. 223-235; Horyń Lidia: Wpływ założeń polityki oświatowej na koncepcje programowane wychowania przedszkolnego w Polsce w latach 1945-1989 s. 237-251; Cz. 4: Edukacja a społeczeństwo: Bartnicka Kalina: Polska Akademia Nauk. Refleksje o jej powstaniu, działalności 
i znaczeniu dla polskiej nauki s. 281-303; Kromolicka Barbara: Wolontariat w kulturze chrześcijańskiej s. 305-316; Górska Lucyna: Pedagogia i pedagogika jezuicka - w poszukiwaniu inspiracji dla współczesnego wychowania s. 317-331.

65. Z DZIEJÓW polskiej teorii i praktyki edukacyjnej. Pod red. Władysławy Szulakiewicz. Toruń 2009 Wydaw. Nauk. Uniw. Mikołaja Kopernika ss. 249, tabl. 1, il.

Materiały z sympozjum, Olsztyn 2009.

Treść: Szulakiewicz W.: Z dziejów uczestnictwa historyków wychowania w zjazdach historycznych s. 7-16; Krukowski Jan, Ryś Jan: Wkład ośrodka krakowskiego w rozwój teorii pedagogicznej XV i XVI wieku s. 19-32; Michalska Iwonna: Działalność Naukowego Towarzystwa Pedagogicznego (1928-1958) na rzecz rozwoju nauk o wychowaniu s. 33-52; Wałęga Agnieszka: Koncepcje podręcznika historii wychowania w świetle propozycji autorów i opinii recenzentów s. 53-74; Falkowska Joanna: Wychowanie narodowe jako wyzwanie dla polskiej edukacji. Poglądy Stanisława Pigonia (1885-1968) s. 75-87; Żołądź-Strzelczyk Dorota: Szkolnictwo różnowiercze w Wielkopolsce s. 91-114; Kochanowicz Jerzy: Bezpłatne szkolnictwo jezuickie jako wyzwanie dla Akademii Krakowskiej s. 115-126; Dybiec Julian: Idea uniwersytetu w Polsce XIX i XX wieku s. 127-146; Tomaszewski Roman: Koncepcje uczelni wojskowej w Polsce XIX wieku (między edukacyjną autarkią a otwarciem) s. 147-170; Michalski Grzegorz: Działalność Związku Inspektorów Szkolnych w Rzeczypospolitej Polskiej (1922-1939) s. 171-188; Walasek Stefania: Unifikacja szkolnictwa Kresów Północnych po 1922 roku s. 189-200; Massalski Adam, Kula Ewa: Nauczyciele i wybitni uczniowie szkół ziemi kielecko-radomskiej w latach 1862-1905 s. 203-226; Jakubiak Krzysztof, Jamrożek Wiesław: Rodzina polska jako środowisko wychowawcze na przełomie XIX i XX wieku s. 227-236; Jackowska Kinga: Instytucja „salonu towarzyskiego” w obyczajowości XIX-wiecznej w świetle poradników dla panien s. 237-249.

66. ZAJĄC Halina: Ewolucja teorii nauczania języka rosyjskiego w szkole polskiej w latach 1950-2000. Cz. 1. Kraków 2008 Wydaw. Nauk. Akad. Pedagog. ss. 170, nlb. 1, sum., rez. Akad. Pedagog. im. Komisji Edukacji Nar. w Krakowie. (Prace Monograficzne; nr 482).

Toż. Cz. 2. Kraków 2009 Wydaw. Nauk. Uniw. Pedagog. ss. 223, nlb. 1, sum., rez. Uniw. Pedagog. im. Komisji Edukacji Nar. w Krakowie. (Prace Monograficzne; nr 544).

\section{Okres do 1795 roku}

67. BALANA-MROCZKOWSKA Emilia: Szkolnictwo parafialne w dekanacie człuchowskim w okresie staropolskim. [W:] Związki Chojnic i Człuchowa na przestrzeni dziejów. Materiały z konferencji naukowej, 6-7 czerwca 2008 r. Zespół red. Ewa Homa-Rożek [i in.]; red. z. Wiktor Zybajło. Człuchów 2009 s. 21-30.

68. BEDNARSKI Łukasz: Zasady funkcjonowania Komisji Edukacji Narodowej jako pierwszego Ministerstwa Oświaty. Roczniki Humanistyczne. T. 57: 2009 z. 2 s. 99-110, sum.

69. FELIŃSKI Andrzej Wojciech: Uwarunkowania funkcjonowania pruskich domów poprawy i domów pracy przymusowej w XVIII wieku. Szczecin 2008 Zapol ss. 160, il. Uniw. Szczeciński. Wydz. Humanist.

70. KAMIŃSKA Janina: Sprawa Szkoły Głównej Wielkiego Księstwa Litewskiego na Sejmie Grodzieńskim w 1793 roku. Rozprawy z Dziejów Oświaty. T. 46: 2009 s. 5-24, sum.

71. KAMLER Anna: Education of noblemen's sons in 16th century Poland. Acta Poloniae Historica. [T.] 99: 2009 s. 125-136.

72. KROWICKI Stanisław Ludwik: Przedrozbiorowy podręcznik geografii przyczyną protestu posła rosyjskiego. Przegląd Historyczno-Oświatowy. R. 52: $2009 \mathrm{nr}$ 3/4 s. 5-11.

Podręcznik Karola Wyrwicza wydany w 1768 r. został oprotestowany przez księcia Mikołaja Repnina. 
73. KUCZER Jarosław: Szlachcic „In Christo seeliglich”. Edukacja młodzieży szlacheckiej Śląska w czasach habsburskich na przykładzie księstwa głogowskiego. Studia Zachodnie. Nr 11: 2009 s. 29-41, sum.

74. MIESZEK Małgorzata: Kategoria milczenia w staropolskich intermediach szkolnych. Acta Universitatis Lodziensis. Folia Litteraria Polonica. [Vol.] 12: 2009 s. 51-60, sum.

75. MIĘDZY przeszłością a współczesnymi mediami. Z problemów historii, kultury i edukacji. Pod red. Piotra Kąkola i Anny Reglińskiej-Jemioł. Gdańsk 2009 Wydaw. Uniw. Gdańskiego ss. 173, tabl. 16, il., Zsfg.

Z treści: Puchowski Kazimierz: Edukacja młodzieży z Prus Królewskich w kolegiach szlacheckich Rzeczypospolitej s. 116-128; Sacha Magdalena: Szkoła dla dziewcząt Luizy von Krockow - marzenia i rzeczywistość s. 129-151; Furmaniak Mariola: Niektóre zabawy dzieci w XVIII wieku z Krokową w tle s. 152-160.

76. PELCZAR Roman: Szkolnictwo w Tarnowie w czasach hetmana Jana Tarnowskiego (1488-1561). [W:] Jan Tarnowski. Hetman i mąż stanu. Dla uczczenia 450 rocznicy wydania w Tarnowie dzieła Consillium rationis bellicae (1558-2008). Materiały. Pod red. Edmunda Juśko. Tarnów 2009 s. 67-73.

77. PIELACHA Krystian: Szkolnictwo parafialne w dawnej ziemi stężyckiej (XVI-XVIII w.). Radzyński Rocznik Humanistyczny. T. 7: 2009 s. 33-53.

78. PODEDWORNY Ireneusz: Nauczanie w klasztorze kanoników regularnych w Mstowie na przełomie średniowiecza i czasów nowożytnych. [W:] Przemijanie i trwanie. Kanonicy Regularni Laterańscy w dawnej i współczesnej Polsce. Pod red. Kazimierza Łataka, Ireny Makarczyk. Kraków 2008 s. 451-464.

79. POLANOWSKI Leszek: Konwikt Boboli w Sandomierzu. Zeszyty Sandomierskie. R. 16: 2009 nr 27 s. 32-39.

Kamienica w rynku przekazana przez Jakuba Bobolę jezuitom na bursę dla młodzieży uczącej się w Collegium Gostomianum, pozostająca w ich rękach w 1. 1635-1777.

80. RUCIŃSKI Robert: Studia uniwersyteckie mieszczan wielkich miast pruskich w średniowieczu. Klio. [R. 8]: 2008 nr 10 s. 31-86, sum.

W tym w Krakowie.

81. SOKOŁOWSKA Katarzyna: Dziecko i dzieciństwo w hagiografii staropolskiej. Poznańskie Studia Teologiczne. T. 23: 2009 s. 213-231, sum.

Do końca XVIII w.

82. STAROPOLSKI etos wychowania. Pod red. Elwiry J[olanty] Kryńskiej. Białystok 2006 Trans Humana ss. 157, il.

Do XVIII w.

83. SZEWCZYK Agnieszka: Nazwiska uczniów I LO w Tarnowie w latach 1784-1794. Rocznik Tarnowski. [T.] 10: 2005/2006 [dr.:] 2006 s. 45-57.

84. WOŚ Jan Władysław: Polacy na uniwersytecie w Perugii. Rocznik Polskiego Towarzystwa Naukowego na Obczyźnie. R. 51: 2007/2008 [dr.:] 2009 s. 138-143.

XVI-XVII w.

85. ZABRANIAK Sławomir: Misjonarze św. Wincentego a Paulo w seminarium gnieźnieńskim (do 1795 r.). Nasza Przeszłość. T. 112: 2009 s. 207-233.

XVIII w. 


\section{Okres 1795-1918}

86. BALIŃSKA Karolina: Warszawskie szkolnictwo dramatyczne przełomu XIX i XX wieku na podstawie ówczesnej prasy. Przegląd Historyczno-Oświatowy. R. 52: 2009 nr 1/2 s. 129-141.

87. BANACH Ryszard: Studia w Instytucie Teologicznym w Tarnowie w latach 1838-1850. Tarnowskie Studia Teologiczne. T. 28: 2009 [z.] 1 s. 17-37, riass.

88. BASZKO Agnieszka: Towarzystwo Pomocy Naukowej dla Dziewcząt Polskich w Wielkim Księstwie Poznańskim w latach 1871-1918. Studia Historica Slavo-Germanica. T. 26: 2004/2005 [dr.:] 2006 s. 99-141, abstr., Zsfg.

89. BEDNARSKI Łukasz: Struktura organizacyjna władz oświatowych Księstwa Warszawskiego 1807-1815. Roczniki Nauk Prawnych. T. 19: 2009 nr 2 s. 267-279, sum.

90. BEDNARZAK-LIBERA Mirosław: Ustawy szkolne w świetle stenogramów Sejmu Krajowego galicyjskiego (1861-1914). Szkolnictwo ludowe. [W:] Idee, państwo, ludowcy. Księga jubileuszowa z okazji 70. Rocznicy urodzin profesora Jana Jachymka. Red. nauk. Ewa Maj, Stanisław Michałowski, Alicja Wójcik. Lublin 2009 s. 110-124.

91. BILICKA Beata: Wkład ks. W[alentego] Gadowskiego i ks. Z[ygmunta] Bielawskiego w przezwyciężenie modelu katechizmu deharbowskiego w Polsce na początku XX wieku. Paedagogia Christiana. [Nr] 19: 2007 s. 181-190, r s.

92. BŁASZCZYK Tomasz: Opieka Towarzystwa św. Wincentego Ț Paulo nad młodzieżą rzemieślniczą we Wrocławiu w latach 1855-1871. Saeculum Christianum. R. 12: 2005 nr 2 s. 119-132, Zsfg.

93. BOGUSZ Monika: Szkoła elementarna w Łęcznej pod zaborem rosyjskim do 1865 roku. Radzyński Rocznik Humanistyczny. T. 7: 2009 s. 57-96.

94. BOŁDYREW Aneta: Matka i dziecko w rodzinie polskiej. Ewolucja modelu życia rodzinnego w latach 1795-1918. Warszawa 2008 Neriton ss. 380, sum., Zsfg, rez.

Rec.: Dormus Katarzyna, Kwartalnik Historii Nauki i Techniki. R. 54: 2009 nr 3/4 s. 297-302.

95. BURZYŃSKA-WENTLAND Lidia: Strajki Szkolne w Prusach Zachodnich w latach 1906-1907. Gdańsk-Sopot 2009 Wydaw. Uniw. Gdańskiego ss. 255, il.

Rec.: Maliszewski Tomasz, Acta Univiersitatis Nicolai Copernici. Nauki HumanistycznoSpołeczne. Z. 393: Pedagogika. [Nr] 25: 2009 s. 194-199.

96. CZAPLICKI Bronisław: Katolicka działalność oświatowo-wychowawcza w Petersburgu w drugiej połowie XIX i na początku XX w. (do 1914 r.). Zarys problematyki. Śląskie Studia Historyczno-Teologiczne. [T.] 40: 2007 z. 2 s. 422-434, rez.

Dot. placówek polskich.

97. Czaplicki Bronisław: Szkolnictwo katolickie w Rosji pod koniec XIX i na początku XX w. (do 1917 r.). Zarys problematyki. Ślaskie Studia Historyczno-Teologiczne. [T.] 41: 2008 z. 1 s. $84-95$, rez.

Dot. gł. polskich szkół.

98. ĆWIK Władysław: Przybysze z Galicji na uniwersytecie w Innsbrucku do 1918 r. - prawnicy i medycy. [W:] Państwo, prawo, społeczeństwo w dziejach Europy Środkowo-Wschodniej. 
Księga jubileuszowa dedykowana profesorowi Józefowi Ciągwie w siedemdziesięciolecie urodzin. Kom. red. Adam Lityński [i in.]. Katowiec-Kraków 2009 s. 131-140.

99. DORMUS Katarzyna: Antonina Krechowiecka (1791-1831). Zapomniana lwowska publicystka początku XIX wieku o wychowaniu dziewcząt. Rozprawy z Dziejów Oświaty. T. 46: 2009 s. $25-47$, sum.

100. DZIEKOŃSKI Stanisław, Jankowski Henryk: Charakter chrześcijański w pismach Józefa Bilczewskiego jako świadectwo wizji wychowawczej Kościoła na przełomie XIX i XX wieku. Studia Gdańskie. T. 24: 2009 s. 139-147, sum.

101. FUDALA Stanisław: Model wychowania w ujęciu św. Rafała Kalinowskiego na tle nurtów w wychowaniu XIX wieku. Św. Rafał Kalinowski [1835-1907] w służbie Bogu i Ojczyźnie. 100-lecie śmierci (1907-2007). Materiały z sympozjum, Katolicki Uniwersytet Lubelski, 26 października 2007 r. Red. S. Fudala. Kraków 2009 s. 71-94.

102. GALEK Czesław: Metody nauczania w gimnazjum II połowy XIX w. w świetle polskiej literatury beletrystycznej i pamiętnikarskiej. Przegląd Historyczno-Oświatowy. R. 52: $2009 \mathrm{nr}$ 3/4 s. $12-34$.

103. HARATYK Anna: Galicyjskie kolonie lecznicze dla dzieci jako forma profilaktyki zdrowotnej. Acta Universitatis Nicolai Copernici. Nauki Humanistyczno-Społeczne. Z. 392: Pedagogika. [Nr] 24: 2009 s. 79-94.

Przełom XIX/XX w.

104. HARTMANN Stefan: Z dziejów Seminarium Nauczycielskiego w Grudziądzu w drugiej połowie XIX wieku. Rocznik Grudziądzki. T. 18: 2009 s. 103-126.

105. HOMOLA SKĄPSKA Irena: Dole i niedole śląskiego studenta w Krakowie. [W:] Świat, Europa, mała ojczyzna. Studia ofiarowane profesorowi Stanisławowi Grodziskiemu w 80-lecie urodzin. Pod red. Mariana Małeckiego. Bielsko-Biała 2009 s. 441-457.

Andrzej Cinciała (1825-1898).

106. JAWORSKI Wojciech: Zapomniane warszawskie stowarzyszenia oświatowe i wychowawcze (1866-1914). Przegląd Historyczno-Oświatowy. R. 52: 2009 nr 1/2 s. 154-162.

107. JAZOWNIK Maria: Przeciw radykalizmowi młodzieży akademickiej. O konfiskacie i likwidacji krakowskiego „Ruchu” (1891). Toruńskie Studia Bibliologiczne. [R. 2]: 2009 nr 1 s. 33-47, sum.

108. JEMIELITY Witold: Rusyfikacja w gimnazjach łomżyńskich męskim i żeńskim po Powstaniu Styczniowym. Rosjanie na północno-wschodnim Mazowszu w XIX wieku i pierwszej połowie XX wieku. Studia i materiały. Pod red. Michała Gnatowskiego. Łomża 2009 s. 281-292.

109. JURCZYSZYN Marek: Oświata i szkolnictwo elementarne oraz zawodowe w świetle czasopisma „Zorza” 1894-1905. Lubelski Rocznik Pedagogiczny. T. 28: 2009 s. 227-233.

110. KLIN Eugeniusz: Rola gliwickiego gimnazjum dla literackiej edukacji Norberta Bonczyka. Rocznik Muzeum w Gliwicach. T. 21: 2009 s. 37-43, sum., Zsfg.

111. KORYBUT-MARCINIAK Maria: Towarzystwo Wspierania Niedostatnich Uczniów Uniwersyteckich w Wilnie. [W:] Historia, archiwistyka, informacja naukowa. Prace dedykowane profesorowi Bohdanowi Ryszewskiemu. Pod red. Marzeny Świgoń. Olsztyn 2009 s. 113-126. 
112. KORZENIOWSKI Mariusz: Polscy działacze oświatowi w Kijowie w latach 1905-1918. Primum vivere deinde philosophari. O ludziach czynu w dziejach Europy Środkowej i Wschodniej. Księga jubileuszowa dedykowana profesorowi Janowi Rzońcy z okazji siedemdziesiątych urodzin. Pod red. Marka Białokura i Andrzeja Szczepaniaka. Toruń 2009 s. 445-459.

113. KUBICKI Kamil: Lata szkolne, pierwsze utwory poetyckie, udział w organizacjach uczniowskich Gimnazjum Wołyńskiego Karola Sienkiewicza [1793-1860]. Annales Universitatis Mariae Curie-Skłodowska Sec. F: Historia. Vol. 63: 2008 s. 43-65, sum.

114. KULAK Teresa: Działalność Wrocławskiego Stowarzyszenia Nauczycielek (Breslauer Lehrerinnen-Verein) przed I wojną światową. Śląski Kwartalnik Historyczny Sobótka. R. 65: 2009 nr $2 / 3$ s. $315-324$.

115. KULBAKA Jacek: Szkolnictwo krasnostawskie od powstania listopadowego do I wojny światowej. Radzyński Rocznik Humanistyczny. T. 7: 2009 s. 115-123.

116. KWIATEK Jolanta: Ze studiów nad edukacją dziewcząt na Górnym Śląsku (do I wojny światowej). Kwartalnik Opolski. R. 52: 2006 nr 1 s. 17-41.

Od pocz. XIX w.

117. MASSALSKI Adam: Szkolnictwo elementarne we Włoszczowie w czasach zaboru rosyjskiego. [W:] Z przeszłości Włoszczowy. Pod red. Stanisława Janaczka. Włoszczowa 2009 s. 235-260.

118. MEUS Konrad: „Ad tristitiam depellendam” - nieznana dziewiętnastowieczna inicjatywa uczniów wadowickiego gimnazjum. Wadoviana. Nr 12: 2009 s. 31-51.

Dot. różnych pisemek wydawanych w 1. 1885-1887.

119. MILEWSKI Stanisław: Język polski na wokandzie. Palestra. R. 54: $2009 \mathrm{nr}$ 5/6 s. $118-123$.

Wrześnieński proces szkolny w Gnieźnie w dn. 14-17 XI 1901 r.

120. MORYC Katarzyna: Wyrwane z pamiętnika. Zapiski gimnazjalistki. Kraków 1914-1918. Sowiniec. Nr 31: 2007 s. 65-77.

Wspomnienia autorki.

121. MÜLLER Uwe: Die gewerblichen Fortbildungsschulen in den Provinzen Posen und Westpreussen. Instrumente der Polenpolitik, Vorreiter des Staatsschulsystems und Elemente regionaler Entwicklungspolitik. Studia Hist. Oeconom. Vol. 27: 2009 s. 25-39.

122. NIEWĘGŁOWSKA Aneta: Adolf Georg Prowe jako reformator średniego szkolnictwa żeńskiego. Rocznik Toruński. [T.] 36: 2009 s. 185-200.

Torun, XIX w.

123. NIEWĘGŁOWSKA A.: Secondary schools for girls in western Prussia, 1807-1911. Acta Poloniae Historica. [T.] 99: 2009 s. 137-160.

124. PACHOCKA Anna: Dzieciństwo we dworze szlacheckim w I połowie XIX wieku. Kraków 2009 Wydaw. Avalon T. Janowski ss. 267, tabl. 32, il.

125. PAPIEROWSKI Andrzej Jerzy: Organizacja i rozwój szkolnictwa i oświaty w Płocku w czasie I wojny światowej. Notatki Płockie. [R.49]: 2004 [nr] 4 s. 14-23.

126. PELCZAR Roman: Szkoły parafialne na pograniczu polsko-ruskim (ukraińskim) w Galicji w latach 1772-1869. Lublin 2009 Wydaw. KUL ss. 343. KUL Jana Pawła II. 
127. RĘDZIŃSKI Kazimierz: Szkolnictwo galicyjskie na uchodźstwie wojennym (1914-1918). Częstochowa 2008 Wydaw. im. Stanisława Podobińskiego Akad. im. Jana Długosza ss. 245, nlb. 3, XXIV, il., sum., Zsfg. Wydaw. im. Stanisława Podobińskiego Akad. im. Jana Długosza w Częstochowie.

Rec.: Duda Jerzy, Przegląd Historyczno-Oświatowy. R. 52: 2009 3/4 s. 198-200.

128. RÓŻAŃSKI Mieczysław: Problematyka szkolna w obradach Konferencji Episkopatu Prowincji Warszawskiej w okresie niewoli narodowej (1906-1918). Saeculum Christianum. R. 14: 2007 nr 1 s. 121-134, sum.

129. RYBAK Arkadiusz: Szkoła elementarna w Zagórzu i jej rozwój w latach 1816-1868. [W:] Z dziejów Zagórza. Pod red. nauk. Dariusza Rozmusa i Sławomira Witkowskiego. Sosnowiec 2008 s. 59-72.

130. SCHUTTE Christoph: Die Königliche Akademie in Posen (1903-1919) und andere kulturelle Einrichtungen im Rahmen der Politik zur Hebung des Deutschtums”. Marburg 2008 Verlag Herder-Institut ss. VIII, 431, il., streszcz. (Materialien und Studien zur Ostmitteleuropa-Forschung; 19).

131. SŁAWIŃSKI Piotr: $O$ prywatnych żeńskich szkołach średnich funkcjonujących w Sandomierzu w I połowie XIX w. Zeszyty Sandomierskie. R. 14: 2007 nr 24 s. 27-29.

132. SŁAWIŃSKI P.: Szkoły prawosławne w Sandomierzu. Zeszyty Sandomierskie. R. 15: 2008 nr 26 s. 29-34.

133. SMYKOWSKI Janusz: Uczeń w okowach autokracji. Wpływ systemu wychowawczego gimnazjum rosyjskiego na rozwój społeczny ucznia. Biuletyn Historii Wychowania. [Nr] 24: 2008 [dr.: 2009 s. 61-69, sum.

134. SOSNOWSKA Joanna: Geneza Łódzkiego Chrześcijańskiego Towarzystwa Dobroczynności. Biuletyn Historii Wychowania. [Nr] 24: 2008 [dr.:] 2009 s. 71-84, sum.

Zał. w 1885 r.

135. SZKOŁY średnie w guberni warszawskiej i radomskiej w świetle raportów wizytatorów Wincentego Smacznińskiego i Piotra Sofjano z 1853 roku. [Wyd.] Karol Poznański. Przegląd Historyczno-Oświatowy. R. 52: 2009 nr 1/2 s. 101-128.

136. SZMYT Andrzej: Gimnazjum i Liceum Wołyńskie w Krzemieńcu w systemie oświaty Wileńskiego Okręgu Naukowego w latach 1805-1833. Olsztyn 2009 Wydaw. Uniw. WarmińskoMazurskiego ss. 417, nlb. 1, tabl. 31, il., sum., rez., zmst.

Rec.: Danowska Ewa, Annales Universitatis Paedagogicae Cracoviensis. Folia 66: Studia Historica. [T.] 8: 2009 s. 287-290; Wałęga Agnieszka, Acta Universitatis Nicolai Copernici. Nauki Humanistyczno-Społeczne. Z. 393: Pedagogika. [Nr] 25: 2009 s. 215-217.

137. SZWANKOWSKI Jerzy: Rolnicza Szkoła Zimowa w Człuchowie w latach 1885-1916. [W:] Związki Chojnic i Człuchowa na przestrzeni dziejów. Materiały z konferencji naukowej, 6-7 czerwca 2008 r. Zespół red. Ewa Homa-Rożek [i in.]; red. z. Wiktor Zybajło. Człuchów 2009 s. 82-92.

138. SZWARC Andrzej: Stare i nowe pola aktywności społecznej w Królestwie Polskim po 1905 roku. Stowarzyszenia oświatowe i kulturalne (przegląd problematyki). [W:] Na drogach do Niepodległej. Inicjatywy obywatelskie Polaków w XIX i na początku XX w. Red. nauk. Andrzej Stawarz. Warszawa 2009 s. 7-17. 
139. UNVERRICHT Hubert: Musik und Musikpflege in der Ritterakademie zu Liegnitz [Legnica]. Silesia nova. Bd. 5: 2008 H. 2 s. 28-32.

XVIII-XIX w.

140. WNĘK Jan: Problemy oświatowe Sądecczyzny na kartach „Szkoły” 1868-1918. Rocznik Sadecki. T. 37: 2009 s. 250-265.

141. WNĘK J.: Problemy polskiego szkolnictwa zaboru pruskiego i rosyjskiego na kartach „Szkoły” 1868-1914. Biuletyn Historii Wychowania. [Nr] 24: 2008 [dr.:] 2009 s. 23-46, sum.

142. WOJCIECHOWSKI Mieczysław: Strajk polskich dzieci szkolnych na Pomorzu w 1906 r. w opinii prasy polskiej („Pielgrzym”) i niemieckiej („Neue Preussiche Zeitung”). [W:] Ludzie, idee, wojny. Studia z dziejów Europy Środkowowschodniej. Księga pamiątkowa z okazji 70. rocznicy urodzin profesora Włodzimierza Jastrzębskiego. Red. Tomasz Kawski, Jacek Maciejewski. Bydgoszcz 2009 s. 187-195.

143. WYDER Grażyna: Działalność edukacyjna kobiet-Polek w Wielkim Księstwie Poznańskim w drugiej połowie XIX wieku jako czynnik kształtowania świadomości narodowej. Rocznik Lubuski. T. 35: 2009 cz. 1 s. 85-100, abstr.

144. ŻYWICKI Jerzy: Budowa Gimnazjum Gubernialnego w Lublinie. Lubelski Rocznik Pedagogiczny. T. 28: 2009 s. 197-210, il., plan.

XIX-XX w.

\section{Okres 1918-1939}

145. BARTKOWIAK Edyta: Formacje zakonne wobec problemu dzieci pozbawionych opieki w Polsce w latach 1918-1939. Zielona Góra 2009 Oficyna Wydaw. Uniw. Zielonogórskiego ss. 295.

146. BOGUC Krystyna: Dzieci z Szarleja. Rocznik Mińskomazowiecki. Z. 17: 2009 s. 78-84.

Wycieczka śląskich dzieci do Warszawy, 1 VIII $1928 \mathrm{r}$.

147. DWORZECKI Jacek: Szkoła Policji Województwa Śląskiego w Świętochłowicach (1922-1926). [W:] Społeczne konteksty edukacji. Pod red. Kazimierza Rędzińskiego i Mirosława Łapota. Gliwice 2009 s. 261-272.

148. GONTAREK Alicja: Stan szkolnictwa żydowskiego w Mińsku Mazowieckim w dwudziestoleciu międzywojennym. Rocznik Mińskomazowiecki. Z. 17: 2009 s. 85-113.

149. HALICKI Krzysztof: „Gregorianum” (1931-1939). Miesięcznik Gimnazjum w Świeciu nad Wisłą. Acta Cassubiana. T. 9: 2007 s. 93-117.

150. JAKUBOWICZ Andrzej: Duszpasterstwo młodzieży w Polsce w okresie międzywojennym 1918-1939. Studium historyczno-pastoralne. Siedlce 2009 Unitas ss. 243, nlb. 2, sum. (Teologia Praktyczna; 16).

151. JAMROŻEK Wiesław: Praktyka i myśl edukacyjna Drugiej Rzeczypospolitej - w 90 rocznicę odzyskania niepodległości. Biuletyn Historii Wychowania. [Nr] 24: 2008 [dr.:] 2009 s. $121-127$, sum. 
152. JAROSZUK Teresa: Szkoła trudów i nadziei. Edukacja w seminarium nauczycielskim w świetle wspomnień Stanisława Orła. Przeglad Historyczno-Oświatowy. R. 52: 2009 nr 3/4 s. $62-76$.

153. JASTRZĘBSKI Jarosław: Prywatne szkolnictwo akademickie II Rzeczypospolitej. Przeglad Historyczno-Oświatowy. R. 52: 2009 nr 3/4 s. 52-61.

154. JUŚKO Edmund: Powszechne szkolnictwo prywatne i dla mniejszości narodowych w powiecie tarnowskim w latach 1918-1939. Rocznik Tarnowski. [T.] 12: 2007/2008 [dr:.] 2008 s. 167-171.

155. JUŚKO E.: Wychowanie przedszkolne w powiecie tarnowskim w latach 1918-1939. Rocznik Tarnowski. [T.] 13: 2008 s. 119-123.

156. KIEŁTYK-ZABOROWSKA Izabela: Dziecko i dzieciństwo w świetle pedagogiki okresu międzywojennego. Studia i Materiały Polonistyczne. T. 9: 2009 s. 93-108.

157. KOCHAN Katarzyna Barbara: Edukacja elementarna i elementarze porozbiorowe w II Rzeczypospolitej. Kraków 2009 Impuls ss. 96, il.

158. KOŁTUN Weronika Barbara: Oświata pozaszkolna w powiecie zamojskim w latach 1918-1939. Lubelski Rocznik Pedagogiczny. T. 28: 2009 s. 211-216.

159. KOZDROWSKI Stanisław: Szkoła Policyjna w Mostach Wielkich (1928-1939). Policjanci. 2009 s. 9-17.

160. KROCHMALSKA-GAWROSIŃSKA Ewa: Wkład Jerzego Ostrowskiego w propagowanie edukacji obywatelskiej w Polsce w latach 1918-1939. Piotrkowskie Studia Pedagogiczne. T. 14: 2009 s. 59-69.

161. KRUSZYŃSKA Elżbieta: Dydaktyczny charakter powieści dla dziewcząt w dwudziestoleciu międzywojennym. Toruń 2009 Grado ss. 293.

162. KRZYWICKI Ludwik: Ekscesy antyżydowskie na polskich uczelniach w latach trzydziestych XX w. Układ edytorski, oprac. red. Leszek Lachowiecki. Warszawa 2009 Tow. Wydawnicze i Liter.; na zlec. Stow. Społ.-Kult. Warszawa w Europie ss. 151, nlb. 1.

163. ŁAPOT Mirosław: Recepcja idei i systemu wychowawczego Janusza Korczaka w małopolskich placówkach opieki nad sierotą żydowską (1918-1939). [W:] Społeczne konteksty edukacji. Pod red. Kazimierza Rędzińskiego i Mirosława Łapota. Gliwice 2009 s. 247-259.

164. ŁOZOWSKA-MARCINKOWSKA Kamilla: Problematyka edukacji dziewcząt na łamach czasopism kobiecych w latach 1918-1939. Biuletyn Historii Wychowania. [Nr] 24: 2008 [dr.:] 2009 s. 85-97, sum.

165. MARKIEWICZOWA Hanna: Społeczna akcja likwidacji analfabetyzmu na Kresach Wschodnich II Rzeczypospolitej. Studia Theol. Varsaviensia. R. 45: 2007 [nr] 1 s. 209-222.

166. MULCZYŃSKI Jarosław: Poznańska Zdobnicza. Historia Państwowej Szkoły Sztuk Zdobniczych i Przemysłu Artystycznego w Poznaniu w latach 1919-1939. Oprac. graf. Mirosław Pawłowski. Poznań 2009 Akad. Sztuk Pięknych ss. 715, nlb. 1, il.

Tekst równol. pol., ang.

167. OKŁA Grażyna: Wielokulturowość w nauczaniu historii w okresie Drugiej Rzeczypospolitej. Kielce 2008 Wydaw. Uniw. Humanist.-Przyrodniczego Jana Kochanowskiego ss. 182 , nlb. 2. 
168. OPINIA Ministerstwa Spraw Wojskowych z 1934 r. o programach nauki w publicznych szkołach powszechnych oraz w gimnazjach państwowych. [Wyd.] Eugeniusz Piwowarski. Przeglad Historyczno-Oświatowy. R. 52: 2009 nr 3/4 s. 111-118.

169. POROŻYŃSKI Henryk: Kształtowanie oświaty w powiecie chojnickim w latach 1920-1939 (na przykładzie gimnazjum i liceum w Chojnicach). [W:] Z dziejów powiatu chojnickiego w II Rzeczypospolitej. Chojnice 2008 s. 22-42.

170. PRZENIOSŁO Małgorzata: Obsada katedr profesorskich na uczelniach akademickich w II Rzeczypospolitej (na przykładzie matematyków). Czasy Nowożytne. T. 22: 2009 s. 199-214, sum.

171. PRZYBOŚ Małgorzata K: Historia w dziennikach szkolnych zawarta. Dzienniki z międzywojennej Andrzejówki. Almanach Muszyny. [R. 19]: 2009 s. 203-211.

172. RUSEK Adam: Od „Grzesia” do „Gazetki Miki”. Dzieje czasopism obrazkowych dla młodzieży w II Rzeczypospolitej. Rocznik Historii Prasy Polskiej. T. 12: 2009 z. 2 s. 57-76, sum., streszcz.

173. SAMSEL Agata: Rodzina jako środowisko wychowawcze w okresie Drugiej Rzeczypospolitej. Przegląd Historyczno-Oświatowy. R. 52: 2009 nr 1/2 s. 29-49.

174. SAWICKI Leszek: Moje lwowskie szkoły. Rocznik Lwowski. 2008/2009 [dr.:] 2009 s. $211-244$.

Przedwojenne i wojenne wspomnienia szkolne.

175. STAWISZYŃSKA Anita: Problematyka oświaty i wychowania w dwudziestoleciu międzywojennym na łamach „Dziennika Bydgoskiego”. Kronika Bydgoska. T. 30: 2008 [dr.:] 2009 s. $273-303$.

176. TOMASZEWSKI Patryk: Wychowanie w publicystyce działaczy Ruchu NarodowoRadykalnego „Falanga”. Glaukopis. Nr 13/14: 2009 s. 51-67.

177. TOPIJ-STEMPIŃSKA Beata: Działalność edukacyjna Krucjaty Eucharystycznej w Polsce międzywojennej. Kraków 2009 Wyższa Szkoła Filoz.-Pedagog. Ignatianum; WAM ss. 287, tabl. 43, il., Zsfg. Wyższa Szkoła Filoz.-Pedagog. Ignatianum. (Studia Pedagogiczne).

\section{Okres 1939-1945}

178. BĘDKOWSKA Hanna: Tajne nauczanie w powiecie łukowskim w czasie okupacji hitlerowskiej (1939-1944). Radzyński Rocznik Humanistyczny. T. 7: 2009 s. 135-145.

179. BREZA Bogusław: Kultura. Oświata. Życie religijne. [W:] Kościerzyna i powiat kościerski w latach II wojny światowej 1939-1945. Pod red. Andrzeja Gąsiorowskiego. Kościerzyna 2009 s. $227-295$.

180. BURAK Marek: Wyższa Szkoła Techniczna we Wrocławiu (Technische Hochschule Breslau) w czasie II wojny światowej. [W:] Festung Breslau 1945. Historia i pamięć. Red. Tomasz Głowiński. Wrocław 2009 s. 263-280.

181. CEBRAT Tadeusz: Szkoła Zawodowa Głównych Warsztatów Kolei Wschodniej w Tarnowie 1940-1944 (Berufsschule des Ostbahn Ausbesserungswerkes). Rocznik Tarnowski. [T.] 10: 2005/2006 [dr.:] 2006 s. 181-192. 
182. CHMIELEWSKI Witold [Jan]: Administracja szkolna w świetle koncepcji środowiska oświatowego ugrupowania „Ojczyzna” i „Kultury Polskiej”. Przegląd Historyczno-Oświatowy. R. 52: $2009 \mathrm{nr} 1 / 2$ s. $67-75$.

Lata 1939-1940.

183. CHOWANIAK Anna: Nauczyciele tajnego nauczania w latach okupacji w Kętach. Almanach Kęcki. [T.] 13: 2009 s. 68-77.

Zawiera też spis nauczycieli.

184. GROCHOWINA Sylwia: Straty osobowe środowiska nauczycielskiego województwa pomorskiego w roku 1939. [W:] Wokół strat ludności pomorskiej w latach (1939-1945). Materiały z XVII sesji naukowej w Toruniu w dniu 21 listopada 2007 roku. Pod red. Doroty Kromp, Katarzyny Minczykowskiej i Jana Szilinga. Toruń 2008 s. 91-103.

185. IGNATOWICZ Aneta: Tajna oświata i wychowanie w okupowanej Warszawie. Warszawa 2009 Fund. Warszawa Walczy 1939-1945; Bellona ss. 191, nlb. 1, tabl. 24, il. (Warszawskie Termopile 1939-1945).

186. KORZENIOWSKA Krystyna: Nauczanie w Pińczowie w okresie okupacji hitlerowskiej. [W:] Opowieści wojenne z Ponidzia. T. 2. Pod red. Andrzeja Kozery. Kielce 2009 s. 114-132.

187. KRAJEWSKI Miron: Kartki z pamiętnika. Rocznik Mińskomazowiecki. Z. 17: 2009 s. $250-251$.

Gimnazjum Koedukacyjne Tow. Szkół Średnich w Mińsku Mazowieckim, 1. 1939-1944.

188. PREISNER Małgorzata: Dzieci i młodzież w Festung Breslau. Rocznik Wrocławski. [T.] 10: 2006 s. 147-153, Zsfg.

189. SCHENK Dieter: Der Lemberger Professorenmord und der Holocaust in Ostgalizien. Bonn 2007 Dietz ss. 308, il.

190. ŚWISTOWSKI Franciszek: Niemieckie i ukraińskie szkolnictwo w powiecie chełmskim w okresie okupacji 1939-1944. Zarys problematyki. Rocznik Chetmski. T. 13: 2009 s. 321-328.

191. TAJNE nauczanie na terenie byłego powiatu będzińskiego w czasie okupacji hitlerowskiej. Kol. red. Elżbieta Witecka, Halina Augustyn. Będzin 2009 ZNP. Oddz. ss. 67, nlb. 7, il. Oddz. ZNP w Będzinie.

192. „TATA Pigoń”. Kartka z dziejów Tajnego Uniwersytetu w Krakowie. Wstęp Janusz S. Gruchała. Krosno 2008 Państ. Wyższa Szkoła Zawodowa ss. 16, il. (Wykłady Krośnieńskie; 2).

Stanisław Pigoń.

193. WALCZAK Marian: Struktura i działalność władz oświatowych w Polsce w latach 1939-1945. Przegląd Historyczno-Oświatowy. R. 52: 2009 nr 1/2 s. 50-66.

194. WALEWANDER Edward: Działalność wychowawcza Kościoła lubelskiego 1939-1945. Przedm. Adam Koseski. Lublin 2009 TN KUL Jana Pawła II ss. 249, nlb. 5, il., Zsfg. TN KUL Jana Pawła II. (Prace Wydziału Nauk Społecznych; 124).

195. WITKOWSKA Agnieszka: Między gettem a niebem, czyli o ostatnim przedstawieniu w Domu Sierot Janusza Korczaka. Kwartalnik Historii Żydów. [R. 9]: 2009 nr 3 s. 312-326, sum.

18 VII $1942 \mathrm{r}$. 
196. WOJTKOWSKA Anna: W siedemdziesiątą rocznicę tajnych kompletów 1939-1945 u Krystyny Kwapiszewskiej. Rocznik Wołomiński. T. 5: 2009 s. 213-264.

W Wołominie.

197. WOŹNIAKOWSKI Krzysztof: Katolicki Uniwersytet Powszechny (1940): placówka oświatowo-kulturalna i wydawnicza polskiej społeczności uchodźczej na Węgrzech okresu II wojny światowej. Toruńskie Studia Bibliologiczne. [R. 2]: 2009 nr 2 s. 9-26, sum.

198. WRZESIEŃ 1939. Wspomnienia uczniów wadowickiego gimnazjum i liceum. Red. Piotr Wyrobiec, Marcin Witkowski. Wadowice 2009 Centrum Kultury im. Marcina Wadowity ss. 264, il.

\section{Okres 1945-1989}

199. BRENDA Waldemar: Młodzież i środowiska oświatowe w opinii PZPR w woj. olsztyńskim na przełomie lat czterdziestych i pięćdziesiątych. [W:] Polska północno-wschodnia w okresie stalinizmu. Spojrzenie z perspektywy półwiecza. Pod red. Krzysztofa Sychowicza, Emilii Świętochowskiej-Bobowik, Waldemara F. Wilczewskiego. Białystok-Warszawa 2009 s. 103-123.

200. CABAK Beata: Rozwój szkolnictwa wyższego w latach 1945-1950 (na obszarze późniejszego województwa katowickiego). Zaranie Śląskie. R. 63: 2006 nr 11 s. 19-31, Zsfg.

201. CHMIELEWSKI Witold [Jan]: Sprawa nauki religii w szkole w okresie Tymczasowego Rządu Jedności Narodowej. Przeglad Historyczno-Oświatowy. R. 52: 2009 nr 3/4 s. 89-104.

202. DĘBNICKA Regina: Notatka z konferencji w dniu 28 maja 1958 r. w gmachu Komitetu Powiatowego PZPR w Łomży w sprawie omówienia programu uroczystości „Dni Łomży” i Zjazdu Wychowanków Średnich Szkół Łomżyńskich w czerwcu 1958 r. [Wyd.] Wawrzyniec Kłosiński pt. Jak komitet partyjny dyscyplinował Towarzystwo. Ziemia Łomżyńska. [R.] 10: 2009 s. 28-43.

203. DOBRUCKA Marlena: Nauka religii poza szkołą na terenie diecezji kieleckiej w latach 1961-1973. Archiwa, Biblioteki i Muzea Kościelne. T. 92: 2009 s. 53-70, Zsfg.

204. DOROSZEWSKI Jerzy: Niższe szkoły rolnicze na Lubelszczyźnie w latach 1944-1948. Przeglad Historyczno-Oświatowy. R. 52: $2009 \mathrm{nr}$ 3/4 s. 77-88.

205. DWORACZEK Kamil: Działalność samokształceniowa wrocławskiego Studenckiego Komitetu Solidarności. [W:] Letnia Szkoła Historii Najnowszej 2008. Referaty. Pod red. Moniki Bielak, Łukasza Kamińskiego. Warszawa 2009 s. 125-138.

206. FIC Maciej: Wpływ ludności napływowej na funkcjonowanie szkolnictwa województwa śląskiego w latach 1945-1950. Rocznik Lubuski. T. 35: 2009 cz. 1 s. 135-148, abstr.

207. FILIPKOWSKI Tadeusz: Średnie szkoły ogólnokształcące na Warmii i Mazurach (1945-1947). Echa Przeszłości. [T.] 10: 2009 s. 313-327, sum.

208. GAWLIK Stanisław: Kształtowanie się polskiego szkolnictwa w powiecie brzeskim. Kwartalnik Opolski. R. 52: 2006 nr 4 s. 87-93.

209. Gawlik S.: Szkoła polska w dobie zniewolenia komunistycznego (1945-1989). Refleksje z oddali czasu. Opole 2009 Wydaw. Uniw. Opolskiego ss. 264, il. Uniw. Opolski. 
210. GULCZYŃSKA Justyna: Problematyka oświaty w obradach okrągłego stołu. Acta Universitatis Nicolai Copernici. Nauki Humanistyczno-Społeczne. Z. 392: Pedagogika. [Nr] 24: 2009 s. 45-66, sum.

211. HOSZOWSKA Mariola: Między prymatem ideologii a dydaktycznym pragmatyzmem. Z problemów edukacji historycznej po 1956 roku. Klio. [R. 9]: $2009 \mathrm{nr} 12$ s. 85-107, sum.

212. JEDYNAK Witold: Koncepcja społeczeństwa, rodziny i wychowania młodego pokolenia w PRL w listach pasterskich i komunikatach Episkopatu Polski z lat 1945-1956. Studia Sandomierskie. T. 16: 2009 z. 1/2 s. 231-252, sum.

213. „JESTEŚCIE naszą wielką szansą”. Młodzież na rozstajach komunizmu 1944-1989. Pod red. Pawła Ceranki, Sławomira Stępnia. Warszawa 2009 IPN - KŚZpNP ss. 493, nlb. 1, tabl. 24, il. IPN -KŚZZNP.

Materiały z konferencji naukowej, Warszawa, 17 XI 2006 r.

Treść: Ceranka P., Stępień S.: Wstęp s. 7-11; Grajewski Andrzej: Wychowanie ateistyczne dzieci i młodzieży w Europie Środkowo-Wschodniej jako element walki z Kościołem. Wybrane problemy s. 15-29; Lesiakowski Krzysztof: Powszechna Organizacja „Służba Polsce” w systemie organizacyjnym państwa polskiego (1948-1955) s. 30-47; Wierzbicki Marek: Postawy członków ZMP wobec rzeczywistości epoki stalinizmu s. 48-78; Rafalska Dominika: „Pokolenie ZMP”. Urodzeni w latach trzydziestych - ich wizja socjalizmu na łamach tygodnika „Po prostu” s. 79-96; Turkowski Romuald: Działalność wiejskich organizacji młodzieżowych w PRL (1944-1989) s. 97-137; Hausner Wojciech: Związek Harcerstwa Polskiego w latach 1944-1964. Pomiędzy tradycją służby Bogu, Polsce i bliźnim a komunistycznym „przechwyceniem” s. 138-147; Sadowska Joanna: Znaczenie polityczne Związku Młodzieży Socjalistycznej (1957-1976). Założenia i rzeczywistość s. 148-156; Krajewski Kazimierz: Konspiracyjne organizacje młodzieżowe na terenie województwa mazowieckiego w latach 1945-1956 s. 157-202; Baran Adam F.: Harcerstwo niezależne. Od Niezależnego Ruchu Harcerskiego do Związku Harcerstwa Rzeczypospolitej s. 203-215; Choma-Jusińska Małgorzata: „Zmieniajcie rzeczywistość!". Duszpasterstwo akademickie o. Ludwika Wiśniewskiego w Lublinie w latach 1972-1981 s. 216-233; Spałek Robert: „Szara biel i czerwień flag”. Obraz rzeczywistości lat osiemdziesiątych w polskiej muzyce rockowej s. 234-238; Czaputowicz Jacek: Walka o legalizację Niezależnego Zrzeszenia Studentów s. 239-285; Czaputowicz J.: Działania Służby Bezpieczeństwa i kontrwywiadu wojskowego wobec ruchu „Wolność i Pokój” s. 286-300; Krasucki Eryk: W kręgu postaw uczestników szczecińskiego Ruchu „Wolność i Pokój” s. 301-313; Kwiatek Robert, Wąsowicz Jarosław, Falkiewicz Bogdan: Młodzież aktywna i zorganizowana. Federacja Młodzieży Walczącej w regionie Gdańsk s. 314-321; Dyskusja s. 322-345; Wierzbicki Kazimierz: Mój pobyt w SP. [Służba Polski] s. 349-357; Fedorowicz Jacek: Kultura młodych. Teatry studenckie w połowie lat pięćdziesiątych. [Wspomnienia] s. 358-363; Dokumenty. [Lata 1969-1989] s. 367-470.

214. KONOPKA Hanna: Sytuacja w oświacie na Białostocczyźnie w okresie przełomu 1956 r. [W:] Polska północno-wschodnia w okresie stalinizmu. Spojrzenie z perspektywy półwiecza. Pod red. Krzysztofa Sychowicza, Emilii Świętochowskiej-Bobowik, Waldemara F. Wilczewskiego. Białystok-Warszawa 2009 s. 142-147.

215. KRÓL Joanna: Licea ogólnokształcące w województwie szczecińskim w latach 1948-1961. Toruń 2009 Adam Marszałek ss. 243.

216. KRZYWICKI Andrzej: Poststalinowski karnawał radości. V Światowy Festiwal Młodzieży i Studentów o Pokój i Przyjaźn, Warszawa 1955 r. Przygotowania, przebieg, znaczenie. Warszawa 2009 Trio ss. 334, nlb. 1, il. (W Krainie PRL. Ludzie, sprawy, problemy. Rzeczywistość PRL odczytana z akt, dokumentów, zapisów, twórczości).

217. KTOŚ przecież musiał stanąć prosto. Studencki Komitet Solidarności we Wrocławiu. 1977-2007. Koncepcja publikacji i oprac. tekstów Tomasz Przedpełski; red. Renata Otolińska, T. Przedpełski. Wrocław 2007 Stow. Wspierania Inicjatyw Kult. „Nasze Miasto Wrocław” ss. 49, nlb. 1, il. 
218. KUBIK Władysław: Szczecin “46. „Trzymamy straż nad Odrą”. Szczecin 2006 Pol. Zw. Głuchych. Specjalistyczny Ośr. Diagnozy i Rehabilitacji Dzieci i Młodzieży z Wadą Słuchu im. Marii Góralówny ss. nlb. 2, 95, il. ZHP. Komisja Historii Chorągwi Zachodnio-Pomorskiej.

Ogólnopolski Zlot Młodzieży, Szczecin, 13-14 IV 1946 r.; zawiera też materiały źródłowe.

Toż. Wyd. 2 popr. i uzup. Szczecin 2007 ss. 140, il.

219. KULA Marcin: Człowiek nie jest plasteliną. Historyka. T. 39: 2009 s. 137-148.

Komunistyczne modele edukacyjne w PRL.

220. Kulbaka Jacek: Szkolnictwo specjalne w Polsce w pracach Ministerstwa Oświaty w latach 1956-1961. Przegląd Historyczno-Oświatowy. R. 52: 2009 nr 1/2 s. 82-100.

221. KUSZTELAK Andrzej: Warunki i zasady funkcjonowania polskich szkół przy ambasadach PRL w krajach europejskich w latach 1967-1989. Przeglad Historyczno-Oświatowy. R. 52: 2009 nr $1 / 2$ s. 200-223.

222. LENART Jolanta: Historia szkolnictwa w powiecie kolbuszowskim w latach 1944-1975. Kolbuszowa 2009 Miej. i Pow. Bibl. Publ. ss. 257, il. (Varia Kolbuszowskie).

223. LISTOPAD '80. Czas studentów i służby zdrowia. Pod red. Marka Latoszka. Pelplin 2008 Bernardinum ss. 358, nlb. 2, il.

Z treści: Latoszek M., Leoniuk Katarzyna: Solidarnościowy strajk studentów AMG: lekcja walki politycznej na tle integracji w uczelni s. 15-32; Relacje strajkowe uczestników. Zebrane i przygot. do dr. przez M. Latoszka i K. Leoniuk s. 33-184; Odpowiedzi na ankietę rozesłaną s. 185-207; Refleksje i migawki s. 208-215; Latoszek M.: Uwarunkowania i funkcje studenckich strajków w Trójmieście (strajk w Akademii Medycznej w kontekście innych uczelni) s. 219-271.

224. ŁASZKIEWICZ Rafał: Z PRL-em w nazwie - nadanie Szkole Podstawowej nr 8 w Inowrocławiu imienia XXX-lecia PRL przykładem ideologizacji inowrocławskiej oświaty. [W:] Inowrocław w Polsce Ludowej. Zbiór studiów. Pod red. Tomasza Łaszkiewicza. Inowrocław 2009 s. $167-175$.

225. MARZEC ' 68 z czterdziestoletniej perspektywy. Pod red. Danuty Kisielewicz i Małgorzaty Świder. Opole 2009 Wydaw. Uniw. Opolskiego ss. 318, tabl. 2, il. Uniw. Opolski.

Z treści: Kisielewicz D., Świder M.: Wstęp s. 7-11; Czech Jan: Marcowe refleksje. Czterdzieści lat później s. 15-17; Kasprzyk Adam: „Dekada młodych” s. 19-26; Nowy Marek: Chcąc prawdy, przegrałem życiorys s. 27-28; Borkowski Krzysztof: Mój Marzec "68 w opolskiej WSP s. 29-34; Duda Harry: Trochę nitów w mity... s. 35-38; Krzewicki Wiktor: Informacje o wystawie towarzyszącej konferencji „Marzec “68 z czterdziestoletniej perspektywy” s. 39-40; Opolski Marzec '68 - kalendarium wydarzeń. Oprac. Mariusz Patelski s. 41-43; Białokur Marek: Z perspektywy czterdziestolecia. Historiografia polska wobec przełomowych wydarzeń 1968 roku w Polsce i w Czechosłowacji s. 47-66; Koćwin Lesław: Marzec '68 w propagandzie KC PZPR. Mity i fakty s. 67-85; Kotulska Jadwiga: Propagandowy obraz Marca '68 na łamach prasy polskiej s. 87-97; Sielezin Jan Ryszard: Marzec '68 z dolnośląskiej perspektywy s. 99-110; Patelski M.: Ludzie władzy w Opolu w 1968 roku s. 111-118; Tarka Krzysztof: Strajk opolskich studentów w marcu 1968 roku s. 119-132; Benczew Beno: Wydarzenia marcowe 1968 roku na Opolszczyźnie w świetle biuletynów MSW s. 133-141; Bereszyński Zbigniew: Marzec '68 w opolskim środowisku akademickim s. 143-166; Oszytko Jan: Pomarcowa działalność naukowa prof. Maurycego Horna s. 167-175; Mazurkiewicz Marek: Wydarzenia Marca '68 na łamach opolskiej prasy codziennej s. 177-191; Kisielewicz D.: Kierunki i rozmiary pomarcowej emigracji politycznej s. 193-200; Jarząbek Wanda: Zagraniczne reakcje na wydarzenia polskiego Marca 1968 roku w raportach polskich dyplomatów s. 203-218; Świder M.: Wydarzenia 1968 roku w Polsce i w Czechosłowacji w środkach masowego przekazu Republiki Federalnej Niemiec s. 225-239; Kalinowska Monika: Stosunki polsko-izraelskie po 1967 roku s. 277-289; Górska Lena: Dylematy współczesnej żydowskiej tożsamości s. 291-301; Aneks. [Dokumenty z 1. 1968-1978] s. 303-315. 
226. MICHALSKI Andrzej: Wyższe szkolnictwo muzyczne w Polsce w latach 1945-1964. Założenia organizacyjno-programowe i wybrane elementy rzeczywistości. Bydgoszcz 2009 Wydaw. Uniw. Kazimierza Wielkiego ss. 476, nlb. 1., sum.

227. MŁODZIEŻ kontra system. Rola opozycji młodzieżowej w walce o niepodległość w latach 1945-1989. Pod red. Małgorzaty Świder. Opole 2009 PTH. Oddz. ss. 158. PTH. Oddz. w Opolu.

Z treści: Świder M.: Wstęp s. 7-11; Sielezin Jan Ryszard: Młodzież Dolnego Śląska w społecznym oporze wobec władzy w latach 1945-1947 s. 13-25; Stanek Piotr: Polska Akademicka Młodzież Ludowa (PAML) na emigracji s. 27-40; Skobelski Robert: Postawy młodzieży wobec polityki władz na ziemi lubuskiej w okresie stalinowskim s. 41-56; Mazurkiewicz Marek: Echa rewolt studenckich 1968 r. w opolskiej prasie codziennej s. 57-70; Bereszyński Zbigniew: Młodzi opolanie wobec stanu wojennego (na przykładzie konspiratorów z organizacji „Wolność i Niepodległość) s. 71-84; Patelski Mariusz: Opolski Krąg Instruktorów Harcerskich im. Andrzeja Małkowskiego (1980-1982) s. 85-98; Patelski M.: Niezależne Zrzeszenie Studentów w Opolu 1980-1989 s. 99-118; Krzewicki Wiktor: Środowisko studenckie w latach 1985-1989 w Opolu na podstawie wybranych dokumentów i korespondencji opolskiego Wydziału III Wojewódzkiego Urzędu Spraw Wewnętrznych s. 119-131.

228. MŁYNARCZYK-TOMCZYK Anita: Edukacja historyczna w liceach pedagogicznych (1944-1970). Teoria i praktyka. Kielce 2009 Kieleckie Tow. Nauk. ss. 376, il.

229. NABZDYK Zygmunt: Sodalicja Mariańska Akademików w Gliwicach 1946-1949. Oprac. ... Gliwice-Opole 2009 Wydaw. i Drukarnia Świętego Krzyża ss. 175, il.

230. NIEPODLEGŁOŚCIOWE organizacje młodzieżowe na Rzeszowszczyźnie w latach 1944-1956 w świetle dokumentów. Wybór, wstęp i oprac. Bogusław Wójcik. Rzeszów 2009 IPNKŚZpNP ss. 512, tabl. 16, il.

Rec.: Półćwiartek Józef, Rocznik Historyczno-Archiwalny. T. 20: 2007/2008 [dr.:] 2009 s. 283-290.

231. NOWACZYK Jerzy: Duszpasterstwo akademickie w Zielonej Górze w latach 1966-1986 (wspomnienia). Zielona Góra 2009 Wydaw. Diecezji Zielonogórsko-Gorzowskiej ss. nlb. 6, 314, il.

232. PASZKOWSKa Anna: Z badań nad działalnością i dorobkiem pogotowia opiekuńczego w Gdańsku po 1946 roku. Przegląd Historyczno-Oświatowy. R. 52: 2009 nr 3/4 s. 163-175.

233. PIKUŁA Norbert: Pozaszkolne nauczanie religii dzieci i młodzieży w diecezji częstochowskiej (1961-1990). Kraków 2009 Scriptum ss. 232.

234. POGORZAŁA Ewa: Nauczanie języka czeskiego jako ojczystego dla uczniów narodowości czeskiej w Polsce po drugiej wojnie światowej. Przegląd Historyczno-Oświatowy. R. 52: 2009 nr $1 / 2$ s. $163-178$.

235. POWOJENNE losy inteligencji kresowej. Materiały z konferencji naukowej, która odbyła się w Opolu 18-19 listopada 2005 roku. Pod red. Elżbiety Treli-Mazur. Opole 2007 Wydaw. Inst. Śląski ss. 210, nlb. 1, tabl. 16, il. Stow. Wspólnota Polska. Oddz. w Opolu.

Z treści: Hickiewicz Jerzy: Profesorowie Oddziału Elektrotechnicznego Politechniki Lwowskiej w powojennej Polsce s. 171-175; Guzik Antoni: Udział Kresowian w powstaniu i rozwoju Wyższej Szkoły Inżynierskiej w Opolu. [Biogramy] s. 177-186; Trela-Mazur Elżbieta: Wkład Kresowian w rozwój Wyższej Szkoły Pedagogicznej w Opolu s. 187-192; Duda Jerzy: Pionierzy oświaty z Kresów Wschodnich na Śląsku Opolskim s. 193-202.

236. RAPORT Kieleckiej Kurii Diecezjalnej z sierpnia 1950 roku o stanie edukacji religijnej i szkolnictwa katolickiego. [Wyd.] Marlena Dobrucka. Nasza Przeszłość. T. 111: 2009 s. 313-326. 
237. ROŚ Jerzy: Plecami do thumu. Wydarzenia krakowskie 17-24 lutego 1989 r. (fragmenty wspomnień). Arcana. Nr 86/87: 2009 s. 142-158.

Manifestacje uliczne Niezależnego Zrzeszenia Studentów.

238. SIKORA Mirosław: Praca, „wino, kobiety i śpiew”, czyli na Studenckich Praktykach Robotniczych. [W:] Donosem i pałką. Z działań Służby Bezpieczeństwa na Górnym Śląsku i w Zagłębiu Dąbrowskim w latach 1956-1980. Pod red. Adama Dziuby. Katowice-Tarnowskie Góry 2008 s. 127-151.

239. SKONIECZNY Tomasz: Historia szkolnictwa po 1945 roku na terenie gminy Będzino. [W:] Gmina Będzino. Z dziejów dawnych i nowych. Materiały. Pod red. Andrzeja Chludzińskiego. Pruszcz Gdański-Będzino 2009 s. 229-243.

240. SMULSKI Jerzy: „Przewietrzyć zatęchłą atmosferę uniwersytetów”. Wokół literaturoznawczej polonistyki doby stalinizmu. Toruń 2009 Wydaw. UMK ss. 184.

241. SOŁTYSIK Łukasz: Dzieci i młodzież północnokoreańska w Polsce w latach 1953-1954 w świetle wybranych dokumentów. Rocznik Jeleniogórski. T. 41: 2009 s. 195-210, sum., Zsfg.

Aneks źródłowy.

242. STRZELECKA Małgorzata: Trudne kompromisy. Środowisko „Tygodnika Powszechnego” wobec reformy systemu oświaty i wychowania w latach 1945-1989. Toruń 2009 Adam Marszałek ss. 323 .

243. SYRNYK Jarosław: Służba Bezpieczeństwa wobec studentów zagranicznych we Wrocławiu w latach osiemdziesiątych XX w. Aparat Represji w Polsce Ludowej. 1944-1989. [R. 6]: 2009 z. 1 s. 253-265.

244. SZANIAWSKI Maciej: Założenia struktury szkolnictwa podstawowego i status nauczyciela w świetle prawa oświatowego (1945-1972). Prace Naukowe Uniwersytetu Śląskiego. Nr 2722: Wieki stare i nowe. T. 1 (6): 2009 s. 331-351, sum., Zsfg.

245. SZAREK Jarosław: SB wobec młodzieży akademickiej Krakowa między Marcem 1968 a Grudniem 1970 roku. [W:] Strażnicy sowieckiego imperium. Urząd Bezpieczeństwa i Służba Bezpieczeństwa w Małopolsce 1945-1990. Pod red. Filipa Musiała i Michała Wenklara. Kraków 2009 s. $461-488$.

246. SZTABA Sławomir: Baza materialna domów dziecka w województwie rzeszowskim w latach 1944-1955. Przegląd Historyczno-Oświatowy. R. 52: 2009 nr 1/2 s. 179-187.

247. ŚWIĘTOCHOWSKA-BOBOWIK Emilia: Konferencje sierpniowe jako próba indoktrynacji nauczycieli na przykładzie województwa białostockiego (1949-1956). Przegląd HistorycznoOświatowy. R. 52: 2009 nr 1/2 s. 188-199.

248. TOMKIEWICZ Ryszard: Olsztyński rok 1956. Rola studentów w wydarzeniach. Olsztyn 2007 Ośr. Badań Naukowych im. Wojciecha Kętrzyńskiego; Tow. Nauk. im. Wojciecha Kętrzyńskiego ss. 210, il.

249. TOMKIEWICZ R.: Studenci Olsztyna wobec wydarzeń na Węgrzech oraz przemian w Polsce jesienią 1956 roku. Komunikaty Mazursko-Warmińskie. [R. 50]: 2006 nr 3 s. 377-386, Zsfg.

250. TRUDNE drogi. Wspomnienia młodzieży Duszpasterstwa Akademickiego w Kielcach jako świadectwo postaw religijno-patriotycznych (1964-1994). Pod red. Julisława Łukomskiego.

Kielce 2009 Wszechnica Świętokrzyska ss. 285, il. (Prace Wszechnicy Świętokrzyskiej; nr 126).

Antologia pamiętników. 
251. URBANEK Marek: Oświata i szkolnictwo w drugiej połowie XX wieku. [W:] Radłów i gmina radłowska. T. 2. Praca zbior. pod red. Feliksa Kiryka. Kraków-Radłów 2009 s. 9-50.

252. WAGNER Barbara: Strategia wychowawcza w PRL. Warszawa 2009 Neriton ss. 250, nlb. 2, tabl. 8, il., sum.

253. WALLIS Janina: Oświata i kultura w okresie stanu wojennego w województwie zielonogórskim. [W:] Z dziejów Ziemi Lubuskiej po drugiej wojnie światowej. T. 2: Stan wojenny na Ziemi Lubuskiej. Red. nauk. Czesław Osękowski, Robert Skobelski. Zielona Góra 2009 s. $83-127$.

254. WIERZBICKI Marek: Młodzież w PRL. Warszawa 2009 IPN - KŚZpNP ss. 195, nlb. 1, il. IPN - KŚZpNP. (Seria 39/89. Najnowsze dzieje Polski; t. 2).

255. WILK Anna: Szkoła żydowska w Chorzowie w latach 1945-1948. Zeszyty Chorzowskie. T. 9: 2008 s. 154-168, Zsfg.

256. WITKOWSKA-URBAN Ewa: Udział Stefana Truchima [1896-1967] w tworzeniu i rozwoju łódzkiego ośrodka akademickiego. Rocznik Łódzki. T. 55: 2008 s. 123-134, sum.

257. WŁADZE wobec Kościołów i związków wyznaniowych w Wielkopolsce w latach 1956-1970. Pod red. Konrada Białeckiego. Poznań 2009 Oddz. IPN - KŚZpNP ss. 279, nlb. 1, il. (Studia i Materiały Poznańskiego IPN; t. 8).

Materiały z konferencji, 21 XI $2008 \mathrm{r}$.

Z treści: Krupecka Małgorzata: Walka o przetrwanie szkoły sióstr urszulanek SJK w Pniewach w latach 1957-1962 s. 67-94; Wąsowicz Jarosław: Represje wobec Wyższego Seminarium Duchownego Towarzystwa Salezjańskiego w Lądzie nad Wartą w latach 1956-1970 s. 95-113; Wojcieszyk Elżbieta: Niższe Seminarium Duchowne w Wolsztynie 1949-1960 w dokumentach aparatu bezpieczeństwa PRL-u s. 115-128; Reczek Rafał: Laicyzacja szkół w Wielkopolsce w okresie rządów Władysława Gomułki s. 129-147.

258. ŻUKOWSKA Anna Marta: Rysunek i wychowanie plastyczne w szkolnictwie ogólnokształcącym w Polsce po II wojnie światowej. Lublin 2009 Wydaw. UMCS ss. 455, tabl. 25, il.

\section{Okres 1989-2009}

259. CHALIMONIUK Marian: Uwagi o ustawach o Szkolnictwie Wyższym w Polsce z 1990 r. i 2005 r. Ethos inteligencji i meandry szkolnictwa wyższego w Polsce. Red. nauk. Edward Jarmoch. Siedlce 2009 s. 223-230.

260. DZIEDZICZAK-FOLTYN Agnieszka: O reformowaniu szkolnictwa wyższego w Polsce w latach 1989-2009 i towarzyszącej temu debacie publicznej. Przegląd Socjologiczny. T. 58: 2009 [nr] 3 s. 51-75, streszcz., sum.

261. GAWRECKI Lechosław: Jak w Kaliszu i Gnieźnie dyrektorów i nauczycieli kształcono (19932008). Publikacja z okazji jubileuszu 15-lecia Studium Doskonalenia Menedżerów Oświaty w Kaliszu i Gnieźnie. Poznań 2008 Wydaw. eMPi2 Mariana Pietraszewskiego ss. 128, nlb. 1, tabl. 16, il.

262. GOŁOŚ Michał, Wawrzyńczuk Andrzej: Szkolnictwo ukraińskiej mniejszości narodowej w Polsce na przełomie XX i XXI wieku. [W:] Mniejszość polska na Ukrainie, mniejszość ukraińska w Polsce po 1989 roku. Red. Agnieszka Kasińska-Metryka, Michał Gołoś. Chełm-Katowice 2009 s. $145-156$. 
263. HOŁOJUCH Mateusz: Historia fundacji rozwoju ośrodka akademickiego w Rzeszowie w latach 1993-2008. Resovia Sacra. R. 16: 2009 s. 287-298, sum.

264. LESZCZYŃSKI Paweł: Wpływ strukturalnej reformy edukacji z 1999 roku na kondycję finansową jednostek samorządu terytorialnego województwa lubuskiego w latach 1999-2000. [W:] Post hominium memoriam. Pod red. nauk. Elżbiety Skorupskiej-Raczyńskiej i Przemysława Słowińskiego. Gorzów Wielkopolski 2009 s. 277-287.

265. MURDZEK Wojciech: Aby byli jedno. Rocznik Świdnicki. T. 32: 2004 [dr:.] 2005 s. 147-155.

Dzieje Fundacji Pomocy Biednym Dzieciom „Ut Unum Sint”, od 1990 r.

266. SKAWIŃSKI Ryszard: Reforma szkolnictwa zawodowego w „Gazecie Wyborczej” w latach 1992-2002. Studia Etckie. [T.] 11: 2009 s. 191-207, Zsfg.

\section{Oświata polonijna}

267. BORUCIŃSKA Izabela: Rola edukacji, religii i mass mediów w kształtowaniu świadomości narodowej diaspory polskiej w krajach nadbałtyckich. Rocznik Polonii. Nr 2: 2006 s. 76-95.

XX-XXI w.

268. KLIMCZAK Małgorzata: Polska szkoła średnia w Harbinie - Gimnazjum im. Henryka Sienkiewicza (1915-1949). Polskie ślady na Dalekim Wschodzie. Polacy w Harbinie. Materiały z konferencji naukowej zorganizowanej w Szczecinie w dniach 23-24 października 2008 r. Pod red. Andrzeja Furiera. Szczecin 2008 s. 169-178.

269. KUKLA Wiesław, Miszczuk Marian: Harcerska działalność wydawnicza w Stanach Zjednoczonych Ameryki w latach 1913-2008. Polska - dwa światy: Kraj i Polonia. Materiały z międzynarodowej konferencji naukowej „Polacy w Ameryce Północnej - 400-lecie”. Red. nauk. Wiesław Jan Wysocki, Waldemar Gliński. Warszawa 2009 s. 347-388.

270. MISZCZUK Marian: U źródeł powstania ZHP poza granicami kraju (Wielka Brytania 1940-1941). Rocznik Historii Harcerstwa. [T.] 5: 2009 s. 63-81.

271. NAUCZYCIELE - uczniowie. Solidarność pokoleń. Szkolnictwo i oświata polska na Zachodzie w czasie drugiej wojny światowej. Pod red. Teresy Zaniewskiej. Warszawa 2007 Wydaw. SGGW ss. nlb. 2, 407, il.

Rec.: Miąso Józef, Rozprawy z Dziejów Oświaty. T. 46: 2009 s. 190-193.

272. SIBIGA Zygmunt: Zadania etniczne szkół polonijnych Stanów Zjednoczonych. Polska dwa światy: Kraj i Polonia. Materiały z międzynarodowej konferencji naukowej „Polacy w Ameryce Północnej - 400-lecie”. Red. nauk. Wiesław Jan Wysocki, Waldemar Gliński. Warszawa 2009 s. 293-303.

273. WOŹNIAKOWSKI Krzysztof: Świetlica Polska w Budapeszcie: działalność kulturalnooświatowa i artystyczna w latach 1939-1944. [W:] Społeczeństwo, kultura, inteligencja. Studia historyczne ofiarowane Profesor Irenie Homoli-Skąpskiej. Pod red. Elżbiety Orman i Grzegorza Niecia. Kraków-Warszawa 2009 s. 569-603. 


\section{Dzieje szkół różnych stopni}

\section{Szkoły podstawowe i zakłady wychowawcze}

274. BARYLAK Marzena, Cora Teresa, Sipowicz Ilona: Zarys dziejów Szkoły Podstawowej nr 10 im. Księcia Bolka II świdnickiego w Świdnicy. Rocznik Świdnicki. T. 35: 2007 [dr.:] 2008 s. $93-112$.

Od 1956 r.

275. BOŚ Jan Zygmunt: Historia wsi i szkoły w Kozodrzy 1882-1982. Krosno 2009 Apla ss. 141 , nlb. 1 , il.

276. CHODKIEWICZ Bogdan, Stankiewicz Mariola: Gimnazjum Nr 3 im. Jana Pawła II. Rocznik Wołomiński. T. 5: 2009 s. 123-140.

Lata 2002-2009.

277. CZAJKA Henryk: Szkoła Podstawowa im. ks. Jerzego Popiełuszki w Niewodnej 1859-2009. Niewodna-Krosno 2009 Krośnieńska Oficyna Wydawnicza ss. 76, tabl. 14, il.

278. CZECH Ewa: Historia szkoły w Przyszowicach. Przyszowice 2008 [B.w.] ss. 92, nlb. 2.

Szkoła Podstawowa im. Karola Miarki, XVII-XXI w.

279. ĆWIK Jerzy: Zarys historii Szkoły Podstawowej w Zbylitowskiej Górze do roku 1945. Rocznik Tarnowski. [T.] 10: 2005/2006 [dr.:] 2006 s. 137-162.

Od XIX w.

280. DUTKA Władysława: Historia szkoły w Zawadzie (1907-2007). Rocznik Sądecki. T. 37: 2009 s. 59-88.

Obecnie Zespół Szkół Podstawowo-Gimnazjalnych nr 2.

281. GALEK Czesław: Prywatne przedszkole w Łabuniach w latach 1933-1936. Archiwariusz Zamojski. [Nr 8]: 2009 s. 39-50.

282. KALEJDOSKOP szkolnych zdarzeń 1989-2009. Księga pamiątkowa w XX rocznicę powstania Społecznej Szkoły Podstawowej nr 1 im. Józefa Piłsudskiego i w X rocznicę Społecznego Gimnazjum nr 1 im. Zbigniewa Herberta. Pod red. Jerzego Gizy. Kraków 2009 Zespół Szkół Społ. nr 1 ss. 247, il.

W Krakowie.

283. KORZENIOWSKI Andrzej: Szkoła Podstawowa nr 2 - rys historyczny. Rocznik Kolski. Nr 2: 2009 s. 89-93.

Od $1961 \mathrm{r}$.

284. LATOCHA Krzysztof Adam: Szkoła Podstawowa w Rychłowicach 1930-1977. Wieluń 2009 Krzysztof Adam Latocha ss. 88, il.

285. NABOŻNY Marcin: Powstanie, rozwój i funkcjonowanie oświaty w latach 1882-2007 (na przykładzie Szkoły Podstawowej w Nawsiu k. Wielopola Skrzyńskiego). Nasza Przeszłość. T. 112: 2009 s. 351-366.

286. NIEWĘGŁOWSKA Ewa: Historia Szkoły Podstawowej w Białce koło Radzynia Podlaskiego. Radzyń Podlaski 2009 Radzyńskie Stow. Inicjatyw Lokalnych; Radzyńskie Tow. Nauk. (Libra) ss. 219, il.

XX-XXI w. 
287. NOPARLIK Przemysław: Historia szkoły w Mikołowie-Borowej Wsi na tle dziejów miejscowości. Mikołów 2009 MBP ss. 120, il.

XIX-XXI w.

288. [OSIEMDZIESIĄT] 80 lat szkoły podstawowej w Jabłonicy. Praca zbiorowa. Skład zespołu red. Elżbieta Berkowicz [i in.]. Krosno 2009 P.U.W. „Roksana” ss. 210, tabl. 14, il.

289. RADOMSKA Arleta: Każde pokolenie ma własny czas... Czterdzieści lat Szkoły Podstawowej im. majora Henryka Sucharskiego w Licheniu Starym (1968-2008). Konin 2009 Wydaw. Państ. Wyższej Szkoły Zawodowej ss. 125, nlb. 1, il.

290. SIWIEC Katarzyna: Miękinia. Nasze gniazdo. 100 lat Szkoły Podstawowej w Miękini. Kraków 2009 Wydaw. i Druk. Tow. Słowaków w Polsce ss. 87, nlb. 1, il.

Szkoła Podstawowa im. Krystyny i Andrzeja Potockich, XX-XXI w.

291. [STO] 100 lat Publicznej Szkoły Podstawowej w Jeżowem Centrum 1909-2009. Stalowa Wola-Jeżowe 2009 Wydaw. Sztafeta; na zlec. Zespołu Szkół w Jeżowem Centrum ss. 133, nlb. 2, il.

292. [STO PIĘĆDZIESIĄT] 150 lat szkolnictwa w Iwoniczu. Red. Małgorzata Jakubowicz, Maria Szajna; współpr. Leszek Krukar [i in.]. Iwonicz-Krosno 2009 Szkoła Podstawowa; Krośnieńska Oficyna Wydawnicza ss. 228, tabl. 88, il.

293. [SZEŚĆDZIESIĄT] 60 lat Zespołu Szkół przy ul. Młodych Techników we Wrocławiu 1949-2009, 10 lat Gimnazjum nr 37 we Wrocławiu 1999-2009. Zespół red. Jerzy Królik [i in.]. Wrocław 2009 Zespół Szkół nr 18 ss. 202, nlb. 2, il.

294. SZKOŁA im. Józefa Wybickiego w Liskowie. Lisków 2005 Kom. Obchodów Jubileuszu SP ss. 183 , il.

Rec.: Dolat Jarosław, Kronika Wielkopolski. 2006 nr 1 s. 102-104.

295. SZKOŁA Podstawowa i Gimnazjum w Rzepinie im. mjr. Jana Piwnika „Ponurego”. Historia i teraźniejszość. Zespół red. Róża Koszarska-Duda [i in.]. Rzepin-Starachowice 2009 Zespół Szkół; U.P.Z.P. „Dorand” T. S. Cisek ss. 63, il.

XX-XXI w.

296. SZKOŁA starsza od Nowej Huty. 190-lecie szkoły (1818-2009) i uroczystość nadania imienia ks. Jana Twardowskiego. Biuletyn informacyjny o szkole na os. Kościelniki, ul. Józefa Sawy-Calińskiego 12, dzielnica Nowa Huta. Zespół red. Anna Szostek Janik, Teresa Bigaj. Kraków 2009 ZSO nr 52 ss. 116, nlb. 1, il. Zespół Szkół Ogólnokształcących nr 52 w Krakowie - Szkoła Podstawowa nr 141, Gimnazjum nr 77 - im. Ks. Jana Twardowskiego.

Treść: Historia szkoły - rok po roku przez 190 lat s. 7-82; Szkoła to nauczyciele, uczniowie, przedmioty s. 83-94; Wspominamy, pamiętamy s. 95-97; Historia szkolnych gazetek s. 98-113; Tradycje, ceremoniały s. $114-116$.

297. SZKOŁA w Boronowie. Historia i teraźniejszość. Oprac. Damian Gołąbek. Boronów 2009 Rada Gm. ss. 46, XVI, il.

XVIII-XXI w.

298. TARNAWSKI Piotr: Przydatność „Arkuszy Ocen” z lat 1945/46-1948/49 do badań nad historią Szkoły Podstawowej nr $1 \mathrm{w}$ Stargardzie. Komunikat. [W:] Stargard w latach 40. i 50. XX w. Problemy społeczno-gospodarcze i polityczne. Materiały pokonferencyjne. Pod red. Jolanty Aniszewskiej i Małgorzaty Machałek. Stargard 2009 s. 199-206.

299. TENDEJ Jacek: Od ks. Kazimierza Siemaszki [1847-1904] do „Radosnej Nowiny 2000”. Piekary-Kraków 2009 Wydaw. Inst. Teol. Księży Misjonarzy ss. 212, il. 
Zakład Wychowawczy im. Ks. Siemaszki w Krakowie i Centrum Edukacyjne „Radosna Nowina 2000” w Piekarach.

300. WAGNER-KOLB Dorothea: Ewangelicka Szkoła Powszechna w Dobrym Mieście. Rocznik Dobromiejski. T. 3: 2009 s. 59-63, Zsfg.

Zał. w 1842 r.

301. WYKAZ uczniów Publicznej Szkoły Powszechnej Nr 2 we Włoszczowie w roku szkolnym 1928/1929. Do dr. przygot. I wprowadzeniem poprzedziła Ewelina Orlińska-Rayska. [W:] Z przeszłości Włoszczowy. Pod red. Stanisława Janaczka. Włoszczowa 2009 s. 323-366.

302. ZESPÓł Szkół w Trzyciążu. Historia szkoły i wspomnienia. Red. Magdalena Bobrowska, Agnieszka Łętocha. Trzyciąż 2009 Zespół Szkół ss. 126, il.

XX-XXI w.

\section{Szkoły średnie ogólnokształcące}

303. BARAŚ Beata: Księga jubileuszowa. 60-lecie LO oraz 30-lecie Zespołu Szkół im. M. Kopernika w Nowym Żmigrodzie. Krosno 2009 Roksana ss. 196, il.

304. BILIŃSKI Piotr: Studium z dziejów Liceum i Gimnazjum św. Anny w Krakowie. Kwartalnik Historii Nauki i Techniki. R. 54: 2009 nr 1 s. 35-77, sum.

W 1. 1586-1949.

305. CHOJNICKIE gimnazjum w życiu społeczno-kulturalnym miasta w II RP. Kol. red. Paweł Boczek [i in.]. Chojnice 2007 Hegard; Tow. Przyj. LO im. Filomatów Chojnickich ss. 48, il. (Biblioteka Filomaty; t. 7).

Treść: Bieszk Stefan: Gimnazjum chojnickie. Rzut oka na jego dzieje s. 3-7; Porożyński Henryk: Gimnazjum i liceum w Chojnicach w latach II Rzeczypospolitej s. 8-18; Gierszewski Janusz: Zrzeszenia uczniowskie działające w chojnickim gimnazjum (1920-1939) s. 19-29; Jaruszewski Kazimierz: Filomackimi ścieżkami Jana Riemera i Franciszka Ringwelskiego s. 30-37; Jaruszewski K.: Zasłużeni wychowankowie gimnazjum chojnickiego (1815-1939). Odc. 27 s. 38-39; Hamerska Małgorzata: Znaczenie patriotyzmu w procesie wychowawczym młodzieży chojnickiego gimnazjum w latach 1920-1939 s. 40-47.

306. DUDA Tadeusz: Akta Szkoły Publicznej Żeńskiej w Starym Sączu z lat 1898-1950 i ich wartość dla badań naukowych. Rocznik Sądecki. T. 37: 2009 s. 266-273.

307. [DZIEWIĘĆDZIESIĘCIOLECIE] 90-lecie „Marcinka” 1919-2009. Oprac. red. Barbara Gronek, Tomasz Gronek. Poznań 2009 Gimnazjum i Liceum im. Karola Marcinkowskiego; Wydaw. Nakom ss. 241, nlb. 3, il., rés., sum.

Dzieje Gimnazjum i Liceum im. Karola Marcinkowskiego w Poznaniu.

308. GANOWIAK Henryk: 20-lecie Towarzystwa Absolwentów Liceum Jezuitów w Gdyni. Rocznik Gdyński. Nr 20: 2008 s. 118-122.

309. GDAŃSKIE Gimnazjum Akademickie. Gdańsk 2008 Wydaw. Uniw. Gdańskiego.

T. 1: Szkice z dziejów. Red. Edmund Kotarski ss. 419.

T. 2: Wybór źródeł z XVI i XVII wieku. Red. Lech Mokrzecki ss. 323.

T. 3: Wybór źródeł od XVI do XVIII wieku. Red. Zbigniew Nowak ss. 561

T. 4: W progach muz i Minerwy. Red. Zofia Głombiowska ss. 261.

Rec.: Markiewiczowa Hanna, Przeglad Historyczno-Oświatowy. R. 52: 2009 3/4 s. 176-182; Pawlak Marian, Rocznik Gdański. T. 67/68: 2007/2008 [dr.:] 2009 s. 183-184; Cichosz Wojciech, Studia Gdańskie. T. 24: 2009 s. 321-325. 
310. GIMNAZJUM i Liceum Ogólnokształcące im. Emilii Plater w Zalesiu Dolnym. Oprac. red. Bogumił Zieliński. Piaseczno-Zalesie Dolne 2009 Stow. Przyj. i Wychowanków Średniej Szkoły Ogólnokształcącej im. Emilii Plater ss. 277, nlb. 3, il.

311. HERRMANN Roman: $\mathrm{Z}$ historią $\mathrm{w}$ tornistrze. Stulecie budynku IV Liceum Ogólnokształcącego im. Marii Skłodowskie-Curie w Chorzowie. Chorzów 2007 IV LO ss. 27, nlb. 1, tabl. 4, il. IV LO im. Marii Skłodowskiej-Curie w Chorzowie.

Rec.: Piegza Marian, Zeszyty Chorzowskie. T. 9: 2008 s. 195-196.

312. KABACIŃSKA Katarzyna: Konferencja naukowa w 450 rocznicę założenia Gdańskiego Gimnazjum Akademickiego (1558-2008), Gdańsk 17 listopada 2008 r. Biuletyn Historii Wychowania. [Nr] 24: 2008 [dr.:] 2009 s. 258-259.

313. KIELAK Tadeusz, Radzio Beata: Z dziejów Liceum Ogólnokształcącego im. Wacława Nałkowskiego (dawniej Gimnazjum i Liceum Ogólnokształcącego im. dra med. Jana Sikorskiego) w Wołominie (1944-2009). Rocznik Wołomiński. T. 5: 2009 s. 87-121.

314. KRAUSE Małgorzata, Chalimoniuk Natalia, Zeman Elżbieta: VI Liceum Ogólnokształcące im. Wacława Sierpińskiego w Gdyni. Rocznik Gdyński. Nr 21: 2009 s. 234-239.

Od 1972 r.

315. KRZYŻOSIAK Magdalena: „Szkoła szczęścia”. Prywatne Gimnazjum Salezjańskie im. św. Edyty Stein. Wrocław-Kamyk 2009 Prywatne Gimnazjum Salezjańskie im. św. Edyty Stein; Druk-Allegro ss. 191, nlb. 1, il.

Współwyd. z: Koszowska Beata: Kronika Prywatnego Gimnazjum Salezjańskiego im. św. Edyty Stein: Wrocław 1999-2009; We Wrocławiu.

316. KULIG. Jubileuszowe wspomnienia absolwentów LO w Wadowicach roku 1959, klasy XI B. Red. Bogda Hardek [i in.]. Kraków 2009 Teza ss. 198, nlb. 1, il.

317. LEŚNIAK Jerzy: Szkoła Chrobrego 1908-2008. Nowy Sącz 2008 Drukarnia Gołdruk Wojciech Gołachowski ss. 449, nlb. 1, XXXII, il.

Akademickie Liceum i Gimnazjum im. Króla Bolesława Chrobrego w Nowym Sączu.

Rec.: Faron Bolesław, Rocznik Saqdecki. T. 37: 2009 s. 386-389.

318. LICEUM w sercu Kaszub 1879-2009. II Zjazd Absolwentów. Kol. red. Krzysztof Jażdżewski, Marian Seyda, Rafał Słomiński. Kościerzyna 2009 Muzeum Ziemi Kościerskiej ss. 47 , nlb. 1 , il.

I LO im. Józefa Wybickiego w Kościerzynie.

319. LIETZ Natalia: Międzynarodowa Konferencja Naukowa „Liceum Krzemienieckie w kontekście rozwoju edukacji i kultury na Wołyniu w latach dwudziestych i trzydziestych XX wieku". Kwartalnik Historii Nauki i Techniki. R. 54: 2009 nr 2 s. 234-236.

Krzemieniec, 10-12 X 2008 r.

320. MAJ Adam: Katolickie Liceum w Radomiu w okresie przemian oświatowych (1991-2006). Radom 2008 Katol. LO im. św. Filipa Neri ss. 222, il.

321. MOLSKA Barbara, Huzarewicz Łucja, Biernaczyk Jarosław: Zapis naszej obecności ciąg dalszy. Gimnazjum i Liceum Żeńskie im. Emilii Sczanieckiej obecnie II Liceum Ogólnokształcącego im. Władysława Reymonta w Ostrowie Wielkopolskim. Ostrów Wielkopolski 2009 Stow. „Nowy Ostrów" ss. 282, il.

XIX-XXI w. 
322. MÜLLER Erich: Vor 200 Jahren wurde die deutsch-evangelische Schule in Lemberg gegründet. Jahrbuch Weichsel-Warthe. Bd. 54: 2008 s. 52-56.

XIX-XX w.

323. NOWICKI Michał: Stan badań nad dziejami Akademii Lubrańskiego. Biuletyn Historii Wychowania. [Nr] 24: 2008 [dr.:] 2009 s. 107-120, sum.

Zał. w 1519 r.

324. OKRUCHY wspomnień. Jubileusz 90-lecia Liceum Ogólnokształcącego im. J. I. Kraszewskiego w Drohiczynie. Zespół red. Maria Dzierżanowska [i in.]. Siemiatycze 2009 Głos ss. 174 , il.

XX-XXI w.

325. PANIENKI z Saskiej Kępy. Z dziejów Pragi Południe. XII Liceum Ogólnokształce im. Marii Skłodowskiej-Curie (1930-1964). Cz. 2. Red. Małgorzata Malewicz. Warszawa 2008 Oficyna Wydaw. Łośgraf ss. 313, nlb. 1, tabl. 22, il.

Cz. 1. 2006.

326. PIETRUSKI Jan Tadeusz: Co nam zostało z tych lat... Białystok 2009 Jan Pietruski ss. 18 , il.

Wspomnienia z Gimnazjum Księży Marianów w Warszawie w okresie stalinizmu.

327. RABIEGA Tadeusz: Gimnazjum Żeńskie im Królowej Jadwigi w Turku. Kronika Wielkopolski. 2004 nr 3 s. 31-40, il.

W 1. 1912-1930.

328. ROSZCZYNIALSKA Jolanta: Liceum Ogólnokształcące Sióstr Urszulanek w Gdyni. Rocznik Gdyński. Nr 21: 2009 s. 150-158.

Od $1930 \mathrm{r}$.

329. SAMSONOWSKA Krystyna: Szkice z przeszłości szkoły pijarów 1909-2009. Kraków 2009 eSPe ss. 169, nlb. 3, il.

LO Zakonu Pijarów im. ks. S. Konarskiego w Krakowie.

330. SPOLSKA-ONISZKO Irena: Działalność reaktywowanej „Szaszkewycziwki” w Przemyślu (1991-2008). Nowa Ukraina. 2007 z. 1/2 s. 165-175, rez., sum.

Zespół Szkół Ogólnokształcących Nr 2 im. Markiana Szaszkewicza.

331. [STO] 100 lat Gimnazjum i Liceum Ogólnokształcącego w Brzozowie (1909-2009). Księga jubileuszowa. Pod red. Zbigniewa Sawki. Rzeszów-Brzozów 2009 Podkarpacki Inst. Książki i Marketingu; na zlec. I LO im. Króla Kazimierza Wielkiego ss. 355, nlb. 1, il.

332. SYPEK Antoni: I Liceum Ogólnokształcące im. Kazimierza Brodzińskiego w Tarnowie 1945-1966. Wyd. 2, poszerz. i popr. Tarnów 2009 „S-Can” Wydaw. Katarzyna i Dariusz Kobylańscy ss. 451 , nlb. 1 , il.

Wyd. 1. 2001.

333. SZKOŁA w cieniu katedry. Praca zbiorowa. Pod red. Andrzeja Szopińskiego. Pelplin 2009 Bernardinum; Collegium Marianum Liceum Katol. im. Jana Pawła II ss. 79, nlb. 1, tabl. 32, il.

XIX-XXI w.

334. TAMTEN „Staszic”. Wspomnienia wychowanków Liceum Ogólnokształcącego im. Stanisława Staszica w Lublinie z 1955-1959 i inne materiały przygotowane na 50-lecie matury. Oprac. Andrzej Wiśliński. Lublin 2009 Mała Pracownia Geograficzna ss. 110, nlb. 1, tabl. 27, il. 
335. TRWAŁOŚĆ pamięci. W 90. rocznicę powstania Gimnazjum i Liceum w Płońsku. Zespół red. Ryszard Buczyński [i in.]. Płońsk 2007 I LO im. H. Sienkiewicza ss. 248, nlb. 5.

$\mathrm{XX}-\mathrm{XXI}$ w.

336. [TRZECIE] III Liceum Ogólnokształcące im Adama Mickiewicza w Bydgoszczy, 1947-2007. Red. Sebastian Malinowski. Bydgoszcz 2007 „Multigraf” R. Ellert, J. Tomczuk ss. 126, il.

Wydano z okazji jubileuszu 60-lecia szkoły.

337. ŻAK Zdzisław: Kuźnia charakterów. Szkoła w ciężkich czasach. Kraków-Czernichów 2009 Nakł. aut.; Wydaw. EJB ss. 205, il.

IV Państwowe Gimnazjum im. Henryka Sienkiewicza w Krakowie, XIX-XXI w.

\section{Szkoły zawodowe}

338. BRODOWSKI Jerzy, Sitek Eligiusz Józef: Historia Liceum Morskiego w Gdyni (1973-1985). Nautologia. R. 44: 2009 s. 104-119.

339. DZIEWIECĆDZIESIĄT lat szkoły średniej w Bodzentynie 1918-2008. Oprac. i red. Stefan Rachtan. Bodzentyn-Starachowice 2009 U.P.Z.P. „Dorand” T. S. Cisek ss. 179, il.

Państwowe Liceum Pedagogiczne, Zespół Szkół Ponadgimnazjalnych nr 1.

340. KĘDZIOR Aleksander: Wspomnienie o działalności i dorobku przemyskich szkół rolniczych. Rocznik Przemyski. T. 45: 2009 z. 5 s. 183-207, sum.

341. KOBYLARZ Małgorzata: Prywatna Szkoła Ochroniarska w Mariówce w latach 1914 -1922. [W:] W służbie słowa pisanego. Księga pamiątkowa dedykowana Halinie Irenie Szumił. Red. Gabriel Bartoszewski. Sandomierz 2009 s. 333-358.

342. KOSMATY Jacek: Tradycje szkolnictwa policyjnego na Śląsku. Dziesięciolecie Szkoły Policji w Katowicach. Policjanci. 2009 s. 29-34.

343. PIĄTKOWSKA-PINCZEWSKA Katarzyna: 90 lat Szkoły Muzycznej w Kaliszu. Rocznik Kaliski. T. 35: 2009 s. 243-252.

344. [PIĘĆDZIESIĄT] 50 lat historii szkoły czyli Od Szkoły Rzemiosł Budowlanych do Zespołu Szkół Budowlanych w Chełmie (1958-2008). Zebr. i oprac. Agnieszka Steć. Chełm 2008 Drukarnia Kresowa ss. 240, il.

345. [PIĘĆDZIESIĘCIOLECIE] 50-lecie Szkół Rolniczych i Wielozawodowych w Grabowie nad Prosną 1958-2008. Mater. zebr. I oprac. zespół red. w skł. Dobrosława Niezgódka [i in.]. Grabów nad Prosną-Ostrzeszów 2008 Oficyna Wydawnicza Kulawiak ss. 120, il.

\section{Zakłady kształcenia nauczycieli (z wyjątkiem szkół wyższych)}

346. CIEŚLEŃSKA Beata: Kształcenie nauczycieli wychowania przedszkolnego na Ziemi Płockiej w latach 1945-1999. Płock 2009 Wydaw. Państ. Wyższej Szkoły Zawodowej ss. 170, il. 
347. MURZYN Andrzej: Od polskiego Seminarium Nauczycielskiego do Filii Uniwersytetu Śląskiego. Zaranie Śląskie. R. 62: 2005 nr 10 s. 185-187, Zsfg. Cieszyn, 24 V 2005 r.; nt.: Myśl pedagogiczna w kulturze Śląska Cieszyńskiego.

348. TRADYCJE kształcenia nauczycieli na Śląsku Cieszyńskim. Studia, rozprawy, przyczynki. Pod red. Wiesławy Korzeniowskiej [i in.]. Katowice 2009 Wydaw. Uniw. Śląskiego ss. 380, nlb. 4, il., sum., Zsfg. (Prace Naukowe Uniwersytetu Śląskiego w Katowicach; nr 2646).

Z treści: Korzeniowska W.: Tradycje kształcenia nauczycieli na Śląsku Cieszyńskim - wprowadzenie s. 9-12; Uglorz Manfred: U źródeł pedagogiki ewangelickiej s. 15-24; Bogus Marzena: Model kariery polskiego nauczyciela na Śląsku Cieszyńskim w czasach austriackich s. 25-42; Kwiatek Jolanta: Możliwości i bariery w edukacji Górnoślązaczek na przełomie XIX i XX wieku s. 43-59; Panic Idzi: Z badań nad gimnazjum jezuickim w Cieszynie (1674-1773) s. 60-68; Dawid Łucja: Ku nowej formacji nauczycielskiej - z badań nad „Miesięcznikiem Pedagogicznym” (1892-1939) s. 69-83; Dymara Bronisława: Poszukiwanie kulturowych korzeni kształcenia nauczycieli w cieszyńskiej uczelni s. 84-94; Spyra Janusz: Seminaria nauczycielskie na Śląsku Cieszyńskim (do 1918 roku) s. 95-116; Rusek Halina: Uniwersytet Śląski z siedzibą w Cieszynie w procesie przemian s. 119-133; Danel-Bobrzyk Helena: Filia Uniwersytetu Śląskiego w Cieszynie kontynuatorem myśli i działań pedagogicznych w kształceniu młodzieży - kilka refleksji s. 134-138; Goriszowski Włodzimierz: Nabywanie doświadczeń pedagogicznych na Uniwersytecie Śląskim - filii w Cieszynie s. 139-142; Szuścik Urszula: Szkice z dziejów kształcenia nauczycieli w Cieszynie (w tym - nauczycieli wychowania plastycznego) s. 143-150; Uchyła-Zroski Jadwiga: Z dziejów edukacji i działalności naukowo-artystycznej Instytutu Muzyki s. 151-155; Solik Ryszard: Od wychowania plastycznego do edukacji artystycznej. Instytutu Sztuki wobec kształcenia artystycznego na uniwersytecie s. 156-164; Ficek Bogdan: Problemy oświaty samorządowej s. 165-168; Olbrycht Katarzyna: Z doświadczeń cieszyńskiej pedagogiki - wątek społeczno-kulturalny s. 169-176; Kania Tadeusz: Specyfika animacji społeczno-kulturalnej na cieszyńskiej „Alma Mater” (od pedagogiki pracy kulturalno-oświatowej do nowoczesnej pedagogiki kultury) s. 177-189; Ogrodzka-Mazur Ewa, Szczurek-Boruta Alina: Problematyka wielokulturowości oraz edukacji międzykulturowej w działalności naukowo-badawczej Katedry Pedagogiki Ogólnej s. 190-195; Żebrokowa Barbara, Żebrok Józef: Nauki ekonomiczne w kształceniu nauczycieli w okresie 1971-2005 s. 196-202; Budniak Józef: Cieszyńska „Alma Mater" w procesie integracji międzywyznaniowej s. 203-210; Seligman Janusz: Funkcjonowanie Filii Uniwersytetu Śląskiego w Cieszynie w okresie stanu wojennego s. 211-216; Pindór Mirosława: Komisja Naukowa ds. Stosunków Polsko-Czeskich i Polsko-Słowackich w Filię Uniwersytetu Śląskiego wpisana s. $217-228$.

349. UBERMAN Marta: Z historii szkolnictwa pedagogicznego w Polsce. Kształcenie nauczycieli rysunku, wychowania plastycznego, plastyki na potrzeby szkolnictwa podstawowego w latach 1944-1989. Rzeszów 2009 Wydaw. Uniw. Rzeszowskiego ss. 287.

\section{Szkoły wyższe}

\section{Akademia Ekonomiczna w Krakowie}

350. PIKOŃ Krzysztof, Sokołowska Agnieszka: Złota księga 80-lecia Akademii Ekonomicznej w Krakowie. 1925-2005. Zespół aut. ...; współpr. merytoryczna Pol. Inst. Biograficzny, Pol. Tow. Biograficzne. Gliwice 2005 Mastermedia; Helion ss. nlb. 6, 160, LXXII, il.

\section{Akademia Górniczo-Hutnicza}

351. DZIEWIĘĆ dekad Akademii Górniczo-Hutniczej w Krakowie 1919-2009. Nine decades of the AGH University of Science and Technology in Cracow 1919-2009. Teksty Anna Biedrzycka; 
zespół red. Barbara Bąk [i in.]. Kraków 2009 Akad. Górniczo-Hutnicza im. Stanisława Staszica ss. 303 , nlb. 1 , il.

Tekst równol. pol., ang.

352. GÓRECKI Henryk: 50 lat istnienia Katedry Automatyki AGH. Osiągnięcia Katedry pod kierownictwem profesora Henryka Góreckiego. Kraków 2008 AGH. Uczelniane Wydawnictwa Nauk.-Dydaktyczne ss. V, nlb. 1, 300, il.

\section{Akademia Podlaska}

353. AKADEMIA Podlaska. Historia i teraźniejszość. Red. nauk. Tamara Zacharuk, Jerzy Kunikowski. Siedlce 2009 Wydaw. Akad. Podlaskiej ss. 205, tabl. 113, il., sum.

Treść: Jówko Antoni: Przedmowa s. 7-8; Gryciuk Franciszek: Wyższa Szkoła Nauczycielska w latach 1969-1977 s. 9-38; Gryciuk F.: Wyższa Szkoła Pedagogiczna w latach 1974-1977 s. 39-54; Dmowski Rafał: Wyższa Szkoła Rolniczo-Pedagogiczna w latach 1977-1999 s. 55-68; Bobryk Adam: Akademia Podlaska s. 69-86; Kunikowski J.: Wydział Humanistyczny s. 87-104; Szamrej-Foryś Iwona: Wydział Nauk Ścisłych s. 105-110; Guliński Piotr: Wydział Przyrodniczy s. 111-124; Kardas Stanisław: Wydział Zarządzania s. 125138; Zacharuk T., Gulati Beata: Kształcenie studentów niepełnosprawnych w Akademii Podlaskiej s. 139-146; Trzpil Izabela Aldona, Wyrzykowska Ewa, Izdebski Dariusz, Jeleń Bronisław: Jednostki międzywydziałowe w czterdziestoletniej historii Akademii Podlaskiej s. 147-157; Kozarska Ewa, Suprum Anna, Goc Tadeusz: Jednostki ogólnouczelniane s. 159-188; Skwierczyński Krzysztof: Duszpasterstwo akademickie w Siedlcach s. 189-194; Barszczewski Wiesław: Władze uczelni 1969-2009 s. 195-201.

\section{Akademia Wychowania Fizycznego w Katowicach}

354. SRAGA Monika: Akademia Wychowania Fizycznego w Katowicach w latach 1970-2005 i jej rola w kształceniu kultury fizycznej. Katowice 2009 Wydawnictwo Akad. Wychowania Fizycznego im. Jerzego Kukuczki ss. nlb. 2, 405, tabl. 2, il. Akad. Wychowania Fizycznego im. Jerzego Kukuczki w Katowicach.

\section{Akademia Wychowania Fizycznego we Wrocławiu}

355. TYSZKIEWICZ Jakub: Studium Wychowania Fizycznego, czyli początki Akademii Wychowania Fizycznego. Rocznik Wrocławski. [T.] 10: 2006 s. 163-181, Zsfg.

Rok 1946.

\section{Gdański Uniwersytet Medyczny}

356. WAJDA Zdzisław: Pro memoria. Pelplin 2009 Bernardinum ss. XII, 371, il.

\section{Katolicki Uniwersytet Lubelski}

357. DZIEKANI Wydziału Teologii Katolickiego Uniwersytetu Lubelskiego Jana Pawła II (1919-2009). Red. Jan Walkusz, Tomasz Moskal. Lublin 2009 Wydaw. KUL ss. 282. KUL im. Jana Pawła II. Wydz. Teologii. Inst. Historii Kościoła. 
358. LOSY pracowników i studentów Katolickiego Uniwersytetu Lubelskiego w czasie okupacji niemieckiej. Oprac. Jan Ziółek. Lublin 2009 TN KUL; KUL ss. 340, il. TN KUL im. Jana Pawła II. (Źódła i Monografie; 343) (Materiały do Dziejów Katolickiego Uniwersytetu Lubelskiego; t. 5).

Antologia wspomnien.

359. [PIĘĆDZIESIĄT] 50 lat teologii pastoralnej na Katolickim Uniwersytecie Lubelskim Jana Pawła II. Przewodn. kom. red. Czesław Krakowiak. Lublin 2009 Wydaw. KUL ss. 290. KUL. Wydz. Teologii. Inst. Teologii Pastoralnej.

360. PRZESTRZEŃ wolności i prawdy. Katolicki Uniwersytet Lubelski w latach 1944-1989. Red. Józef F. Fert. Lublin 2008 Wydaw. KUL ss. 181. KUL Jana Pawła II.

Treść: Fert J. F.: Od redaktora s. 5-8; Szostek Andrzej: Katolicki uniwersytet w Kościele i społeczeństwie. Doświadczenia lubelskie s. 9-24; Pylak Bolesław: Przeżyjmy ten dzień jeszcze raz! [Wizyta Jana Pawła II na KUL, 9 VI 1987 r.] s. 25-48; Chrzanowski Wiesław: Moje spotkania z KUL-em s. 49-62; Łukaszewski Jerzy: KUL z perspektywy pół wieku s. 63-90; Kłoczowski Jerzy: Przestrzeń wolności na KUL-u w latach 1950-1989. Świadectwo walki s. 91-110; Litak Stanisław: Moje potyczki z „władzą ludową” s. 111-123; Bartoszewski Władysław: Mój KUL s. 125-141; Życiński Józef: Prawda i godność w strukturach ideologii s. $143-171$.

361. TRADYCJA i współczesność. 90 lat socjologii w Katolickim Uniwersytecie Lubelskim. Red. Stanisław Fel, Jan P. Gałkowski, Janina M. Zabielska. Lublin 2009 Wydaw. KUL ss. 297. KUL Jana Pawła II. Inst. Socjologii, Pol. Tow. Socjologiczne.

362. Z MYŚLĄ o 90-leciu uniwersytetu. Summarium. R. 37: 2008 [dr.:] 2009 s. 7-54.

Treść: Radziszewski Idzi: Uniwersytet Katolicki w Polsce s. 7-20; Radwan Marian: Od Akademii Duchownej w Petersburgu do Katolickiego Uniwersytetu w Lublinie s. 21-36; Karolewicz Grażyna: Czy w okresie międzywojennym Katolicki Uniwersytet Lubelski miał charakter tylko regionalny? s. 37-45; Karolewicz G.: Wizyta Naczelnika Państwa Józefa Piłsudskiego w Katolickim Uniwersytecie Lubelskim w świetle wspomnień studentów s. 47-54.

\section{Niższe Seminarium Duchowne Towarzystwa Salezjańskiego w Marszałkach}

363. KRAWIEC Jan: Powstanie, działalność i likwidacja Niższego Seminarium Duchownego Towarzystwa Salezjańskiego w Marszałkach. Kraków-Marszałki 2009 Wydaw. Poligrafia Inspektoratu Tow. Salezjańskiego; Salezjanie ss. 159, nlb. 3, tabl. 9, il.

W 1. 1931-1952.

Państwowa Wyższa Szkoła Zawodowa im. Witelona

364. JAWORSKA Kazimiera: Państwowa Wyższa Szkoła Zawodowa im. Witelona w Legnicy. Dolny Ślask. Nr 14: 2009 s. 120-126.

Od 1998 r.

\section{Politechnika Łódzka}

365. TABLICE pamiątkowe w Politechnice Łódzkiej. Album. Koncepcja i oprac. red. Józef Kasprzycki; zdj. Zbigniew Januszek. Łódź 2009 Politechn. Łódzka. Rektorska Komisja Hist. ss. 111, il. Politechn. Łódzka.

Po $1945 \mathrm{r}$. 


\section{Politechnika Poznańska}

366. POLITECHNIKA Poznańska. Dzieje polskiego wyższego szkolnictwa technicznego w Poznaniu 1919-2009. Pod red. Haliny Ganińskiej. Poznań 2009 Wydaw. Politech. Poznańskiej ss. 222 , nlb. 1 , il.

Treść: Ganińska H.: Dzieje poznańskiej uczelni politechnicznej s. 5-29; Kodym-Kozaczko Grażyna: Politechnika w przestrzeni współczesnego Poznania s. 33-39; Jakubowicz Jarosław: Wydział Budowy Maszyn i Zarządzania s. 41-63; Horemska Krystyna: Wydział Elektryczny s. 65-85; Jasiczak Józef: Wydział Budownictwa i Inżynierii Środowiska s. 87-105; Wołyński Andrzej: Wydział Maszyn Roboczych i Transportu s. 107-127; Raciborski Maciej: Wydział Technologii Chemicznej s. 129-144; Dudkowiak Alina: Wydział Fizyki Technicznej s. 145-157; Kodym-Kozaczko Grażyna: Wydział Architektury s. 159-169; Wyrwicka Magdalena: Wydział Informatyki i Zarządzania s. 171-189; Pawlaczyk Anna: Wydział Elektroniki i Telekomunikacji s. 191-203; Szczuka-Dorna Liliana: Studium Języków Obcych s. 205-206; Weiss Wojciech: Studium Wychowania Fizycznego i Sportu s. 207-210; Ganińska H.: Biblioteka Politechniki Poznańskiej s. 211-214; Jakubowski Andrzej: Wydawnictwo Politechniki Poznańskiej s. 215-217.

\section{Politechnika Warszawska}

367. POLITECHNIKA Warszawska 1915-1925. Księga pamiątkowa. Wyd. pod red. Leona Staniewicza. Warszawa 2009 Oficyna Wydawnicza Politech. Warszawskiej ss. nlb. 6, 573, nlb. 2, il., rés.

Repr. oryg.: Warszawa 1925.

Treść: Staniewicz L.: Przedmowa s. III-IV; Staniewicz L.: Szkic historyczny s. 1-88; Staniewicz L.: Gmachy Politechniki s. 89-99; Wydziały Politechniki Warszawskiej s. 100-171; Staniewicz L.: Profesorowie honorowi Politechniki Warszawskiej s. 172-181; Katedry i zakłady naukowe s. 182-456; Młodzież akademicka s. 457-496; Statystyka s. 497-512; Skład osobowy 1915-1925 s. 513-545.

\section{Politechnika Wrocławska}

368. [CZTERDZIEŚCI] 40 lat minęło. Księga jubileuszowa 40-lecia Wydziału Informatyki i Zarządzania Politechniki Wrocławskiej. Zespół red. Hanna Mazur, Agata Gąsiorowska, Katarzyna Jach. Wrocław 2009 Wydz. Informatyki i Zarządzania Politech. Wrocławskiej ss. 336, il.

\section{Szkoła Główna Gospodarstwa Wiejskiego}

369. KATEDRA Maszyn Rolniczych i Leśnych SGGW 1989-2009. [Aut.] Czesław Waszkiewicz [i in.]. Warszawa 2009 Wydaw. SGGW ss. 171, nlb. 1, il.

370. WSPOMNIENIA absolwentów Wydziału Zootechnicznego. Pierwszy rocznik 1951-1955. Zebr. materiałów Janusz Czyż; oprac. red. Barbara Święcińska. Warszawa 2009 Wydaw. SGGW ss. 153, nlb. 3, tabl. 20, il. (Zeszyty Historyczne Stowarzyszenia Wychowanków Szkoły Głównej Gospodarstwa Wiejskiego w Warszawie; z. 8).

\section{Szkoła Podchorążych Lotnictwa w Dęblinie}

371. KACZMARSKA Agnieszka: Ostatnie Orlęta. Współpr. W przygotowaniu albumu Wojtek Matusiak. Karta. [Nr] 60: 2009 s. 34-47.

Zdjęcia ze Szkoły Podchorążych Lotnictwa w Dęblinie; ostatni rocznik szkolony przed wojną. 


\section{Uniwersytet Humanistyczno-Przyrodniczy Jana Kochanowskiego}

372. DROGA do Uniwersytetu 1969-2009. Pod red. Wiesława Cabana, Mieczysława B. Markowskiego. Kielce 2009 Wydaw. Uniw. Humanist.-Przyrodniczego Jana Kochanowskiego ss. 327 , nlb. 1 , tabl. 16 , il.

Z treści: Markowski M. B.: Wstęp s. 11-19; Renz Regina: Władze Uczelni s. 21-34; Małecki Zygmunt, Markowski M. B.: Wydział Humanistyczny s. 35-74; Jaśkowski Bartłomiej: Wydział MatematycznoPrzyrodniczy s. 75-109; Ratajek Zdzisław: Wydział Pedagogiczny i Artystyczny s. 111-131; Kik Kazimierz: Wydział Zarządzania i Administracji s. 133-151; Głuszek Stanisław, Nowak-Starz Grażyna, Szpringer Monika: Wydział Nauk o Zdrowia s. 153-181; Szafraniec Alicja, Domagała Andrzej: Międzywydziałowe Studium Języków Obcych s. 183-191; Pawłowski Rafał: Międzywydziałowe Studium Wychowania Fizycznego i Sportu s. 193-206; Gumuła Teresa: Międzywydziałowe Studium Pedagogiczne s. 207-214; Drążyk Jolanta, Suchojad Henryk: Biblioteka Główna s. 215-234; Marcinkowska Monika: Archiwum s. 235-243; Marcinkowska M.: Wydawnictwo s. 245-254; Kukulski Jerzy: Filia w Piotrkowie Trybunalskim s. 255-271; Semaniak Jacek: Teraźniejszość i przyszłość s. 273-286; Kmieciak Marcin: Kalendarium s. 287-315.

373. FELCHNER Andrzej: Zakład Historii i Teorii Wychowania w Filii Akademii Świętokrzyskiej w Piotrkowie Trybunalskim oraz Piotrkowskie Koło Towarzystwa Historii Edukacji. Biuletyn Historii Wychowania. [Nr] 24: 2008 [dr.:] 2009 s. 135-138, sum.

\section{Uniwersytet im. Adama Mickiewicza}

374. GULCZYŃSKI Andrzej: Prawo na zamku. Wydział Prawno-Ekonomiczny Uniwersytetu Poznańskiego w dawnej rezydencji cesarskiej. Poznań 2009 Wydaw. Nauk. UAM ss. 61, nlb. 3, il.

375. KRUSZEWSKI Eugeniusz S.: Fđ̛rste danske lektor ved Poznań universitet. Folia Scandinavica Posnaniensia. Vol. 10: 2009 s. 37-46.

Ingeborg von Stemann i lektorat języka duńskiego na Uniwersytecie Poznańskim w 1920 r.

376. ZENKTELER Elżbieta: Historia Zakładu Botaniki Ogólnej UAM w Poznaniu, 1919-2009. Poznań 2009 Bogucki Wydaw. Nauk. ss. 48, il.

\section{Uniwersytet Jagielloński}

377. CHWALBA Andrzej: Collegium Maius. Kraków 2009 Księg. Akademicka ss. 239, tabl. 36 , il.

378. CORPUS studiosorum Universitas Iagellonicae 1850/51-1917/1918. [T. 3]: K-Ł. Pod red. Krzysztofa Stopki. Kraków 2009 Historia Iagellonica ss. 1133, il. (Z Prac Archiwum Uniwersytetu Jagiellońskiego. Seria C) (Corpus studiosorum Universitas Iagellonicae in saeculis XVIII-XX; t. 3).

T. 1. 1999.

379. FRANASZEK Piotr: Sprawy Obiektowe. Sprawy Operacyjnego Rozpracowania i Sprawy Operacyjnego Sprawdzania prowadzone wobec Uniwersytetu Jagiellońskiego przez SB w latach 80. [W:] Strażnicy sowieckiego imperium. Urząd Bezpieczeństwa i Służba Bezpieczeństwa w Małopolsce 1945-1990. Pod red. Filipa Musiała i Michała Wenklara. Kraków 2009 s. $427-442$.

380. JACKOWSKI Antoni, Sołjan Izabela: Z dziejów geografii na Uniwersytecie Jagiellońskim (XV-XXI wiek). Kraków 2009 IGiGP UJ ss. 467, tabl. 244, il., sum. UJ. Inst. Geografii i Gospodarki Przestrzennej. 
381. KRAUZE-BŁACHOWICZ Krystyna: Was conceptualist grammar in use at Cracow University?. Studia Antyczne i Mediewistyczne. [T.] 6/41: 2008 s. 275-285.

$\mathrm{XV}$ w.

382. KRONIKA Uniwersytetu Jagiellońskiego za rok akademicki 2004/2005. Red. nacz. Kroniki Andrzej Kazimierz Banach. Kraków 2009 Ośr. Informacji i Promocji UJ ss. 314, nlb. 1, il.

383. ŚLIŻ Małgorzata: Przyczynek do dziejów studiów hebraistycznych na Uniwersytecie Jagiellońskim. Lektorat hebrajskiego na Wydziale Filozoficznym (1926-1939). Analecta. R. 18: 2009 z. $1 / 2$ s. $65-72$, sum.

384. WISZ Piotr: Kierownicy katedr Wydziału Teologicznego Uniwersytetu Jagiellońskiego w latach 1945-1954. Resovia Sacra. R. 16: 2009 s. 159-190, sum.

\section{Uniwersytet Kardynała Stefana Wyszyńskiego}

385. BARTNICKI Roman: Historia i stan obecny Wydziału Teologicznego Uniwersytetu Kardynała Stefana Wyszyńskiego w Warszawie. (W 190. rocznicę bulli papieża Piusa VII z 3 października 1818 r. zatwierdzającej wydział). Studia Theol. Varsaviensia. R. 46: 2008 [nr] 2 s. 13-70, sum.

\section{Uniwersytet Królewiecki}

386. WACŁAWIK Beata: Akta Wydziału Filozoficznego Uniwersytetu w Królewcu przechowywane w Archiwum Państwowym w Olsztynie. [W:] Historia, archiwistyka, informacja naukowa. Prace dedykowane profesorowi Bohdanowi Ryszewskiemu. Pod red. Marzeny Świgoń. Olsztyn 2009 s. $227-232$.

\section{Uniwersytet Lwowski}

387. PUSZKA Alicja: Zarys dziejów nauczania historii Kościoła na Uniwersytecie Lwowskim w XIX wieku. Roczniki Humanistyczne. T. 54: 2006 z.2 s. 37-53, sum.

388. REDZIK Adam: Pracownicy naukowi Wydziału Prawa UJK we Lwowie podczas okupacji sowieckiej w świetle pewnego dokumentu. Rocznik Lwowski. 2008/2009 [dr.:] 2009 s. 171-183.

\section{Uniwersytet Marii Curie-Skłodowskiej}

389. [SZEŚĆDZIESIĄT] 60 lat archeologii w UMCS. Podsumowanie ostatniego dziesięciolecia. Pod red. Jana Gurby, Jerzego Libery. Lublin 2007 Standruk ss. 417, tabl. 24, il. Inst. Archeologii UMCS w Lublinie. (Lubelskie Materiały Archeologiczne; t. 15).

Materiały konferencji, Lublin, 9-10 XII 2005 r.

Rec.: Blombergowa Maria Magdalena, Kwartalnik Historii Nauki i Techniki. R. 54: $2009 \mathrm{nr} 1$ s. 209-212; Gajewska H[alina], Kwartalnik Historii Kultury Materialnej. R. 56: 2008 nr 3/4 [dr.:] 2009 s. $427-429$. 


\section{Uniwersytet Medyczny w Lublinie}

390. FAKTY i ludzie. 40 lat akademickiego kształcenia pielęgniarek w Polsce. Red. nauk. Wiesława Ciechaniewicz, Teresa B. Kulik. Lublin 2009 Print 6 Przeds. Wydawnicze Zw. Niewidomych ss. 415, il. Wydz. Pielęgniarstwa i Nauk o Zdrowiu. Uniw. Medyczny w Lublinie.

391. PIETRUSKI Jan Tadeusz: Niezapomniane lata 1949-1954. Białystok 2009 Naukł. aut. ss. 26 , il.

Wspomnienia ze studiów w Akademii Medycznej w Lublinie.

\section{Uniwersytet Medyczny w Łodzi}

392. GOSTOMSKA Ewa: Powstanie i rozwój Oddziału Analityki Medycznej (Medycyny Laboratoryjnej) na Wydziale Farmaceutycznym Akademii Medycznej (Uniwersytetu Medycznego) w Łodzi. Analecta. R. 18: 2009 z. 1/2 s. 219-310, sum.

W 1. 1977-2007.

\section{Uniwersytet Mikołaja Kopernika}

393. KALEMBKA Sławomir: Urywki wspomnień... Toruń 2009 Adam Marszałek ss. 363, il.

Wspomnienia z Uniwersytetu Mikołaja Kopernika w Toruniu - z czasu studiów historycznych i kariery akademickiej.

394. NALASKOWSKI Stanisław, Szulakiewicz Władysław: Pedagogika toruńska. Od katedry do wydziału. Toruń 2009 Wydaw. Nauk. UMK ss. 148, nlb. 3, tabl. 10, il. (Pedagogika Toruńska).

W 1. 1945-2007.

Rec.: Ślęczka Ryszard, Acta Universitas Nicolai Copernici. Nauki Humanistyczno-Społeczne. Z. 393: Pedagogika. [Nr] 25: 2009 s. 211-214.

395. UNIWERSYET Mikołaja Kopernika. Wspomnienia absolwentów. Plon konkursu ogłoszonego w 2008 r. przez Stowarzyszenie Absolwentów UMK. Oprac. red. Wojciech Streich i Izabela Walczyk. Toruń 2009 Wydaw. Nauk. UMK ss. 145, il.

Lata 1946-1971.

\section{Uniwersytet Opolski}

396. KOSMAN Marceli: „Indeks - Pismo Uniwersytetu Opolskiego” na tle organów prasowych wyższych uczelni w Polsce. [W:] Media dawne i współczesne. Praca zbiorowa. T. 4. Pod red. Bogumiły Kosmanowej. Poznań 2009 s. 129-135.

397. ZAGÓROWSKI Zbigniew: 50 lat Studium Wychowania Fizycznego i Sportu Wyższej Szkoły Pedagogicznej w Opolu i Uniwersytetu Opolskiego. Opole 2009 Wydaw. Uniw. Opolskiego ss. 135 , tabl. 28, il. Uniw. Opolski.

\section{Uniwersytet Pedagogiczny im. Komisji Edukacji Narodowej Krakowie}

398. TRZYDZIEŚCI lat nauczania sztuki na Uniwersytecie Pedagogicznym w Krakowie. Red. Stanisław Sobolewski, Rafał Solewski. Kraków 2009 Wydaw. Nauk. Uniw. Pedagog. ss. 142, nlb. 5, il. 


\section{Uniwersytet Przyrodniczy w Poznaniu}

399. DZIEJE akademickich studiów leśnych w Poznaniu 1919-2009. Nauka dla praktyki leśnej. Pod red. Józefa Brody. Poznań 2009 Wydaw. Uniw. Przyrodniczego ss. 378, il.

400. ZAPISANE w pamięci. 90 lat studiów rolniczo-leśnych w Poznaniu. Oprac. Ewa Strycka, Anna Zielińska-Krybus. Poznań 2009 Wydaw. Uniw. Przyrodniczego ss. 112, nlb. 4, il.

Zawiera: Buczyńska Ewa J., Buczyński Włodzimierz: August Cieszkowski [1861-1932] - myśliciel i uczony z Wierzenicy s. 7-19; oraz 45 innych biogramów postaci, które przyczyniły się do powstania i rozwoju Wyższej Szkoły Rolniczej, potem Akademii Rolniczej, a obecnie Uniwersytetu Przyrodniczego w Poznaniu.

\section{Uniwersytet Przyrodniczy we Wrocławiu}

401. MOROZ Piotr: Uniwersytet Przyrodniczy we Wrocławiu. Historia i współczesność. Dolny Śląs. Nr 13: 2008 s. 120-140.

XIX-XX w.

\section{Uniwersytet Wileński}

402. BERENIS Vytautas: Istoriniai tyrimai Vilniaus universitete tarpukario laikotarpiu. [W:] Ryszard Mienicki (1886-1956). Archiwista i historyk. Pod red. Waldemara Chorążyczewskiego, Roberta Degena. Torun 2009 s. 13-21.

403. SUPRUNIUK Anna, Supruniuk Mirosław Adam: Uniwersytet Stefana Batorego w Wilnie w fotografiach 1919-1939. Toruń 2009 Wydaw. Nauk. UMK ss. XL, 371, il. Bibl. Uniwersytecka w Toruniu. (Materiały do Tradycji Uniwersytetu Mikołaja Kopernika w Toruniu. Miscellanea ad Historiam Universitatis Copernicanae Thoruniensi Pertinentia; t. 2).

Tekst równol. pol., ang., lit.

404. TYLIŃSKA Ewelina: Rola Uniwersytetu Stefana Batorego w popularyzacji wiedzy historycznej w Wilnie. [W:] Ryszard Mienicki (1886-1956). Archiwista i historyk. Pod red. Waldemara Chorążyczewskiego, Roberta Degena. Torun 2009 s. 23-35.

\section{Uniwersytet Wrocławski}

405. GELLES Romuald: Związki uniwersytetu z armią (wojskowi doktoranci h. c. Uniwersytetu Wrocławskiego). Śląski Kwartalnik Historyczny Sobótka. R. 65: 2009 nr 2/3 s. 595-602.

406. GRODZICKI Andrzej: Z dziejów Uniwersytetu Wrocławskiego. Prace Komisji Historii Nauki. T. 9: 2009 s. 108-124.

Od 1505 r.; Uzup.: Dyskusja. Tamże s. 125-132.

407. WRZESIŃSKI Wojciech: Historia na Uniwersytecie Wrocławskim i jej miejsce na mapie polskiej nauki historycznej w latach 1945-2005. Ślaski Kwartalnik Historyczny Sobótka. R. 65: 2009 nr 2/3 s. 609-617. 
408. CELNIK Hanna, Zielonka Magdalena: Poczet rektorów i dziekanów. Warszawa 2009 Warszawski Uniw. Medyczny ss. XII, 294, il.

XIX-XXI w.

409. DZIEJE I Wydziału Lekarskiego Akademii Medycznej w Warszawie (1809-2006): 1809-1916 Wydział Akademicko-Lekarski, 1916-1950 Wydział Lekarski Uniwersytetu Warszawskiego, 1950-1975 Wydział Lekarski Akademii Medycznej, 1975-2006 I Wydział Lekarski Akademii Medycznej. T. 1. Pod red. Marka Krawczyka. Lublin 2007 Wydaw. Czelej ss. XXIV, 344, il.

410. DZIEJE II Wydziału Lekarskiego Warszawskiego Uniwersytetu Medycznego (1975-2009). Pod red. Jerzego A. Polańskiego. Warszawa 2009 Warszawski Uniw. Medyczny ss. 388, il.

411. PERSA Jacek, Marek Anna, Wichrowski Marek: Warszawska uczelnia medyczna w ikonografii i fotografii. Warszawa 2009 Warszawski Uniw. Medyczny ss. 430, il.

XIX-XXI w.

\section{Wojskowa Akademia Techniczna}

412. WYDZIAŁ Nowych Technologii i Chemii Wojskowej Akademii Technicznej 1959-2009. Praca zbiorowa. Pod red. nauk. Wojciecha Włodarkiewicza, Andrzeja Dzisiowa. Warszawa 2009 WAT ss. 165 , tabl. 26 , il.

\section{Wyższa Szkoła Gospodarstwa Wiejskiego w Łodzi}

413. KASPAREK Danuta: Zespół akt Wyższej Szkoły Gospodarstwa Wiejskiego w Łodzi (1945-1950) w zasobie Archiwum Uniwersytetu Warmińsko-Mazurskiego w Olsztynie. Echa Przeszłości. [T.] 10: 2009 s. 407-421, sum.

\section{Wyższe Seminarium Duchowne Diecezji Włocławskiej}

414. GRĘŹLIKOWSKI Janusz: Nauczanie prawa kanonicznego w Wyższym Seminarium Duchownym we Włocławku w XX wieku. Studia Włocławskie. T. 11: 2008 s. 344-370.

415. PONIŃSKI Antoni: Formy inwigilacji Służby Bezpieczeństwa wobec włocławskiego seminarium duchownego w latach 1956-1989. Studia Włocławskie. T. 11: 2008 s. 371-404.

416. [RULKA Kazimierz] R. K.: Z działalności Wyższego Seminarium Duchownego we Włocławku w latach 1945-1950. Oprac. ... Studia Włocławskie. T. 11: 2008 s. 493-508.

\section{Wyższe Seminarium Duchowne „Hosianum”}

417. KOPICZKO Andrzej: O eksmisji Wyższego Seminarium Duchownego „Hosianum” w 1962 roku. Echa Przeszłości. [T.] 10: 2009 s. 423-464, sum.

Zawiera też dokumenty. 


\section{Biografie}

\section{Zbiory życiorysów}

418. BIOGRAFIE nauczycieli działaczy Związku Nauczycielstwa Polskiego województwa podkarpackiego. Cz. 3. Pod red. Stanisława Rosnarczyka. Rzeszów 2009 ZNP. Zarząd Okręgu Podkarpackiego ss. 121, il.

Cz. 1-2. 2005.

419. GRĘDZIK-RADZIAK Agnieszka: Lista polskich nauczycieli z ziem południowowschodnich II Rzeczypospolitej, ofiar represji niemieckich w latach 1941-1944. Cz. II A. Przeglad Historyczno-Oświatowy. R. 52: 2009 nr 3/4 s. 119-162.

Cz. 1. Tamże. R. 51: 2008 nr 1/2; Cz. 2. Tamże. R. 51: 2008 nr 3/4.

420. KICOWSKA Alicja Daniela: Nauczyciele szkół rolniczych na Warmii i Mazurach (1945-1989). Olsztyn 2009 Wydaw. Uniw. Warmińsko-Mazurskiego ss. 186.

421. MASSALSKI Adam: Słownik biograficzny. Nauczyciele szkół średnich rządowych męskich w Królestwie Polskim 1833-1862. Warszawa-Kielce 2007 Rytm; Uniw. Humanist.-Przyrodniczy Jana Kochanowskiego ss. 560.

Rec.: Kula Ewa, Przegląd Historyczno-Oświatowy. R. 52: 2009 3/4 s. 194-197.

422. MROCZKA Wojciech, Piórek Marian: Bohaterscy nauczyciele dzikowieckiej szkoły. Dzikowiec 2009 [B.w.] ss. 56.

Bp Jan Puzio, ks. Stanisław Bąk, ks. Paweł Komorski, ppłk. Karol Hodała, Antoni Kościółka.

423. POLSKA myśl pedagogiczna po 1918 roku. Praca zbiorowa. Pod red. Ewy BrodackiejAdamowicz. Wyd. 3. Siedlce 2009 Wydaw. Akad. Podlaskiej ss. 197.

Treść: Antas Alicja: Florian Witold Znaniecki (1882-1958) s. 11-23; Brodacka-Adamowicz E.: Sergiusz Hessen (1887-1950) s. 25-42; Filipek Agnieszka: Stefania Sempołowska (1869-1944) s. 43-60; Grzegorczyk Barbara: Marian Ignacy Falski (1881-1974) s. 61-72; Klim-Klimaszewska Anna: Zygmunt Mysłakowski (1890-1971) s. 73-84; Lipińska-Rzeszutek Małgorzata: Janusz Korczak (1878/9-1942) s. 85-95; Niewęgłowska Aneta: Kazimierz Sośnicki (1883-1976) s. 97-108; Rzeszutek Lucjan: Helena Radlińska (1879-1954) s. 109117; Skóra Aneta: Bogdan Suchodolski (1903-1992) s. 119-128; Trębicka-Postrzygacz Beata: Lucjan Zarzecki (1873-1925) s. 129-148; Wiśniewska Małgorzata: Marian Porwit (1895-1988) s. 149-155; Dobrowolska Barbara: Antoni Bolesław Dobrowolski (1872-1954) s. 157-171; Klim-Klimaszewska A.: Henryk Rowid (1877-1944) s. 173-184; Brodacka-Adamowicz E.: Władysław Spasowski (1877-1941) s. 185-197.

Wyd. 1. 2001.

424. ZASŁUŻENI instruktorzy Chorągwi Rzeszowskiej ZHP. Red. Małgorzata Jarosińska. Rzeszów 2008 Chorągiew Podkarpacka ZHP; Edytor ss. 32, il. (Harcerskie Biografie).

Treść: Jarosińska M.: Wstęp s. 3; Nowakowska Zofia: Hm. Stanisław Nowakowski (1899-1985) s. 4-8; Kowalik Mariusz: Hm. Maria Morawiec(1908-1992) s. 9-10; Jarosińska M.: Hm. Antoni Gromski (19071982) s. 11-15; Jarosińska M.: Hm. Stanisława Chodzińska (1912-1970) s. 16-18; Kowalik M.: Hm. Stanisław Sokołowski (1900-1982) s. 19-22; Kraus Teresa: Hm. Stanisława Żmudzińska (1890-1964) s. 23-26; Jarosińska M.: Phm. Franciszek Zajdel (1913-1970) s. 27-29; Jarosińska M.: Hm. Stanisława Urbanek (1914-2008) s. $30-32$.

425. ŻOK Halina: „Kolumbowie” z III Liceum. Rocznik Tarnowski. [T.] 14: 2009 s. 61-67. Ofiary II wojny światowej w Tarnowie. 
426. ŻYCIORYSY z Wołominem związane... (Historia miasta pisana ludzkimi losami). Pod red. Marzeny Kubacz, Agaty Sobczak. Wołomin 2009 Urząd Miej. ss. 426, nlb. 6, il. Muzeum im. Zofii i Wacława Nałkowskich „Dom nad Łąkami” w Wołominie.

Z treści: Wojtkowska Anna: Kierowniczka szkoły. Jadwiga Markowska (1892-1945) s. 135-149; Wojtkowska A.: Nauczycielka biologii. Maria Dzwonkowska (1889-1975) s. 153-158; Kubacz M.: Matematyk i pedagog. Józef Kazimierz Piróg (1918-2002) s. 161-165; Drzewińska Małgorzata: Przyjaciel młodzieży. Henryk Lucjan Drzewiński (1925-2000) s. 169-171; Kubacz M.: Historyk i pedagog. Leszek Stefan Podhorodecki (1934-2000) s. 175-182; Wojtkowska A.: Legenda wołomińskiej oświaty. Krystyna Kwapiszewska (ur. 1922) s. 219-226; Wojtkowska A.: Pani od muzyki, którą znają wszystkie dzieci. Urszula Kwapiszewska-Smoczyńska (ur. 1936) s. 229-232; Podhorodecki Leszek: Harcmistrz Mieczysław Cichecki (1908-1975) s. 337-342; Ryszkowski Stefa, Kubacz M.: Harcerska biografia. Stefan Ryszkowski (ur. 1918) s. $345-348$.

Rec.: Noiński Emil, Rocznik Wołomiński. T. 5: 2009 s. 412-414.

\section{Poszczególne biografie}

\section{Bałtruszajtis Andrzej}

427. ZEMEŁA Krzysztof: Andrzej Bałtruszajtis [1881-1941]. Rzecz o pionierze skarżyskiej oświaty i orędowniku nadania praw miejskich Kamiennej. Skarżysko-Kamienna 2005 PiS Agencja Wydawniczo-Poligraficzna Barbara Piątek, Janusz Sieczka ss. 102, tabl. 15, il.

\section{Bartnicki Stanisław}

428. KNOPEK Jacek: Stanisław Bartnicki (1931-1993). Pedagog i organizator uniwersytetu w Nigerii. Rocznik Polonii. Nr 2: 2006 s. 138-140.

\section{Berkowski Jan}

429. SŁUPIANEK Teresa: Życie w służbie Harcerstwu - Jan Berkowski [1932-1981]. Rocznik Świdnicki. T. 36: 2008 [dr.:] 2009 s. 141-143.

\section{Bobkowska Wanda}

430. KUBICA Grażyna: Wanda Bobkowska [1880-1948], nauczycielka i działaczka ewangelicka. [W:] Krakowski szlak kobiet. Przewodniczka po Krakowie emancypantek. Pod red. Ewy Furgał. Kraków 2009 s. 100-107.

XIX-XX w.

\section{Briks Bolesław}

431. NEUMANN Zbigniew: Profesor Bolesław Briks [1901-1988]. Organizator szczecińskiego szkolnictwa zawodowego, średniego i wyższego, członek Stowarzyszenia Inżynierów (i Techników) Mechaników Polskich „SIMP” od 1934 roku. Szczecin 2009 Ośr. Rzeczoznawstwa SIMP Zbigniew Neumann ss. 84, il. (Zasłużeni Mechanicy dla Szczecina, Członkowie SIMP; z. nr 3). 


\section{Dobrowolski Leonard}

432. DRUH Leonard. Ruch harcerski w Supraślu wczoraj i dziś. Pod red. Aleksandra Dobrońskiego i Radosława Dobrowolskiego. Wrocław 2008 Stow. Kulturalno-Artystyczne „Rita Baum" ss. 62, nlb. 2, tabl. 16, il.

L. Dobrowolski (1919-2007).

\section{Fulman Marian Leon}

433. GALEK Czesław: Międzynarodowe sympozjum: „Biskup lubelski Marian Leon Fulman [1866-1945] - pedagog trudnych lat”, Lublin, 13 stycznia 2009 roku. Przeglad HistorycznoOświatowy. R. 52: 2009 nr 3/4 s. 209-212.

\section{Giller Stefan}

434. ROTER-BOURKANE Anna: Stefan Giller [1833-1918] - literat i pedagog. Kronika Wielkopolski. 2004 nr 3 s. 104-106, il.

\section{Goetel Walery}

435. WÓJCIK Zbigniew: Walery Goetel [1889-1972] rektor trudnych czasów Akademii Górniczo-Hutniczej. Kraków 2009 Wydawnictwa AGH ss. 349, nlb. 3, tabl. 66.

\section{Grabowska Celina}

436. GAŁĘZIOWSKA Małgorzata: Celina Grabowska (1962-2005). Rocznik Olsztyński. T. 18: 2009 s. 461-464.

\section{Grella Stanisława}

437. WSPOMNIENIA o Stanisławie Grelli [1907-1984]. Oprac. Małgorzata Baran. Wrocanka 2009 Stow. „Nasza Wrocanka” ss. 71, il.

Wyd. okolicznościowe z okazji nadania szkole we wsi Wrocanka imienia jej kierowniczki w 1. 1959-1968.

\section{Grzegorzewska Maria}

438. FUDALI Robert: O potrzebie dobra w wychowaniu. W 121. Rocznicę urodzin Marii Grzegorzewskiej (1888-1967). Przegląd Historyczno-Oświatowy. R. 52: 2009 nr 1/2 s. 76-81.

439. TOMASIK Ewa: Maria Grzegorzewska. Przeglad Historyczno-Oświatowy. R. 52: 2009 nr $1 / 2$ s. 224-230. 


\section{Jałmużna Tadeusz}

440. MICHALSKI Grzegorz: Tadeusz Jałmużna (1939-2006) - działalność i kierunki badań historyczno-oświatowych. Przegląd Nauk Historycznych. R. 5: 2006 [dr.:] 2007 nr 2 s. 307-312.

\section{Kakowski Aleksander}

441. JAKUBIAK Marek Aleksander: Działalność oświatowo-wychowawcza kardynała Aleksandra Kakowskiego w latach 1914-1938. Saeculum Christianum. R. 14: 2007 nr 1 s. 159-168, sum.

\section{Komeński Jan Amos}

442. FIJAŁKOWSKI Adam: Orbis pictus. Świat malowany Jana Amosa Komeńskiego [1592-1670]. Tł. niem. A. Fijałkowski, Konrad Hierasimowicz, Stephan Waldhoff. Warszawa 2008 Wydz. Pedagog. Uniw. Warszawskiego; Bibl. Uniwersytecka ss. 123, il.

Katalog wystawy w Warszawie i Marburgu.

\section{Korczak Janusz}

443. BRODNICKI Mariusz: Wystawa - „Korczak i jego dzieło”. Przeglad Historyczno-Oświatowy. R. 52: 2009 nr 3/4 s. 207-208.

Otwarta 9 II 2009 r. w Muzeum Wojska w Białymstoku.

\section{Kowalski Jan}

444. KAPŁAN teolog. Księga jubileuszowa z okazji 50. lecia pracy dydaktycznej i wychowawczej księdza profesora Jana Kowalskiego w Wyższym Seminarium Duchownym Archidiecezji Częstochowskiej. Częstochowa 2009 Częstochowskie Wydaw. Archidiec. Regina Poloniae ss. 426, tabl. 18, il.

\section{Łopacki Roman}

445. KOTEŁKO Danuta: Roman Łopacki [1911-2007] pionier świdnickiej oświaty. Rocznik Świdnicki. T. 35: 2007 [dr.:] 2008 s. 117-118.

\section{Machalski Franciszek}

446. ŻUK Mahmud Taha: Towarzystwo Studiów Irańskich w Teheranie (1942-1945). Franciszek Machalski (1904-1979) - iranista, nauczyciel, harcerz. Rocznik Muzutmański. [T.] 7: 2009 s. 100-103. 


\section{Machut Jan Antoni}

447. ŁUDZIK Jerzy: Jan Antoni Machut (1937-2006). Kościerskie Zeszyty Muzealne. [Z.] 3: 2009 s. $190-193$.

\section{Manliu Georg}

448. CHACHAj Marian: Georg Manliu ze Zgorzelca, nauczyciel w szkołach różnowierczych w Polsce i na Śląsku, poeta i lekarz. Res Historica. T. 27: 2009 s. 43-52.

XVI-XVII w.

\section{Marciniak Florian}

449. Wałek Bernard: Wspomnienie o Florianie Marciniaku [1915-1944]. Krakowski Rocznik Historii Harcerstwa. T. 5: 2009 s. 105-120.

\section{Masalski Kazimierz}

450. KORYCKA Magdalena: Między tradycją a współczesnością. Cele wychowania chrześcijańskiego według Kazimierza Masalskiego (1927-1985). Olsztyn 2009 Warmińskie Wydaw. Diec. ss. 128 , il.

451. MASALSKI Kazimierz: Zło sercem zwyciężaj. Życie, działalność i twórczość pedagoga-humanisty. Red. Elżbieta Rusak. Gdańsk 2008 Marpress ss. 96, nlb. 2, tabl. 12, il.

\section{Miller Ludwik Krzysztof}

452. PAWŁOWSKI Piotr: Ludwik Krzysztof Miller - rektor szkoły katedralnej we Włocławku i pisarz XVII wieku. Studia Włocławskie. T. 11: 2008 s. 441-455.

\section{Rokoszny Józef}

453. WOJEWODA Tadeusz: Działalność społeczno-kulturowa i oświatowa ks. Józefa Rokosznego (1870-1931). Sandomierz 2007 Wydaw. Diec. I Drukarnia ss. 453.

Rec.: Warso Albert: Biografia pretekstowa ks. Rokosznego. Zeszyty Sandomierskie. R. 15: 2008 nr 26 s. $91-93$.

\section{Słomkowski Antoni}

454. ZIÓŁEK Jan: Ks. rektor Antoni Słomkowski [1900-1982] w powojennej historii Katolickiego Uniwersytetu Lubelskiego. Warszawskie Studia Teologiczne. [T.] 22: 2009 cz. 2 s. 337-344, resumo. 


\section{Słowikowski Tadeusz}

455. W SETNĄ rocznicę urodzin Tadeusza Słowikowskiego [1907-1993]. Pod red. Czesława Nowarskiego. Kraków 2009 Wydaw. Nauk. Uniw. Pedagog. ss. 127, nlb. 1, tabl. 4, il.

Treść: Żaliński Henryk W.: Otwarcie sesji s. 7-9; Nowarski Cz.: Rys życia i działalności Profesora Tadeusza Słowikowskiego (1907-1993) s. 11-15; Maternicki Jerzy: Tadeusz Słowikowski jako badacz dziejów edukacji historycznej i myśli dydaktyczno-historycznej s. 16-33; Rulka Janusz: Proces poznawczy ucznia podstawowym wyznacznikiem działań edukacyjnych nauczyciela historii w koncepcjach Tadeusza Słowikowskiego s. 34-38; Suchoński Adam: Teoretyczne i praktyczne znaczenie podręcznika Tadeusza Słowikowskiego „Metodyka nauczania Historii” s. 39-49; Zieleniecki Alojzy: Tadeusza Słowikowskiego rola i znaczenie w kształceniu kadry dydaktyków historii w Polsce międzywojennej s. 50-57; Augustynek Kazimierz: Osobowość Tadeusza Słowikowskiego jako nauczyciela akademickiego w uczelni kształcącej nauczycieli s. 58-72; Mazur Janina: Moje spotkania z Mistrzem s. 73-83; Profesor w świetle dokumentów, opinii i recenzji s. 84-107; Spis prac magisterskich i doktorskich przygotowanych pod kierunkiem profesora Tadeusza Słowikowskiego s. 107-126.

Sokół Jan

456. STADNIK Janina: Jan Sokół [1913-1996] - nauczyciel i społecznik. Zeszyty Sandomierskie. R. 15: 2008 nr 26 s. 43-45.

\section{Stroynowski Hieronim}

457. KUKUŁA Artur Jan: Hieronim hrabia Stroynowski, prawnik, ekonomista, fizjokrata (1752-1815). Lublin 2009 Tow. Nauk. KUL Jana Pawła II ss. 236, nlb. 2, il., sum. Tow. Nauk. KUL Jana Pawła II. (Źródła i Monografie; 342) (Prace z Historii Szkolnictwa w Polsce; t. 17).

\section{Strzembosz Tomasz}

458. BARAN Adam F.: Profesor Strzembosz [1930-2004] - historyk Armii Krajowej, harcerz i wychowawca. Warszawa 2009 Światowy Zw. Żołnierzy AK; Rytm ss. 229, nlb. 2, tabl. 32, il. (Biblioteka Armii Krajowej. Bóg, Honor, Ojczyzna; 6).

\section{Szczerkowski Hipolit}

459. CACKOWSKA Joanna: Grodziski chłopak. Szkice o życiu i działalności Hipolita Szczerkowskiego [1895-1960]. Grodzisk Mazowiecki 2009 Starostwo Pow. Grodziskiego ss. 130, nlb. 1, il.

\section{Szuman Henryk Antoni}

460. WAŁĘGA Agnieszka: Ksiądz Henryk Antoni Szuman (1882-1939) jako reprezentant pedagogiki opiekuńczo-wychowawczej. Paedagogia Christiana. [Nr] 18: 2006 s. 165-173, sum. 


\section{Szuman Wanda}

461. PROKOPIAK-LEWANDOWSKA Anna: Działalność Wandy Szuman [1890-1994] na rzecz osób niewidomych - wybrane aspekty. Paedagogia Christiana. [Nr] 19: 2007 s. 167-180, sum.

462. WANDA Szuman. Pedagog i andragog specjalny. Szkice do portretu. Beata BorowskaBeszta red. nauk. Radom 2009 Wydaw. Nauk. Inst. Technologii Eksploatacji - PIB ss. 224, il.

Z treści: Leśniewska Elżbieta: Życie Wandy Szuman s. 19-25; Leśniewska E.: Spuścizna po Wandzie Szuman przekazana Centrum Kształcenia Ustawicznego w Toruniu s. 25-31; Frąckowiak Anna: Artefakty Izba Pamięci Rodziny Szumanów s. 31-33; Siwek Daria, Wiśniewska Ewa: Historia życia Wandy Szuman s. 96-104; Borowska-Beszta B.: Drzewo genealogiczne i linie życia Wandy Szuman s. 105-113; Baranowska Małgorzata, Pruszyńska Agata: Portret osoby, pedagoga i andragoga - codzienność Wandy Szuman s. 114-124; Kirsz Justyna: Wanda Szuman w relacjach członków grupy badawczej s. 124-131; Siwek D., Borowska-Beszta B.: Dokumenty biograficzne i autobiograficzne Wandy Szuman s. 132-156; Pruszyńska A., Siwek D., Borowska-Beszta B.: Galeria fotografii s. 157-198.

\section{Troczewski Zbigniew}

463. DR ZBIGNIEW Troczewski [1904-1980] jako nauczyciel szkół ekonomicznych w Białymstoku. (Wspomnienia wychowanków). Praca zbior. pod red. Henryka Czarniawskiego, Anieli Mazur i Barbary Prokopczuk. Białystok 2009 Książnica Podlaska im. Łukasza Górnickiego ss. 158 , il.

\section{Żeromski Adam}

464. LEONHARD Bolesław: Był złotym skautem. W 90-lecie śmierci Adama Żeromskiego (1899-1918). Krakowski Rocznik Historii Harcerstwa. T. 5: 2009 s. 5-19.

\section{Dzieje oświaty pozaszkolnej}

\section{Oświata dorosłych}

465. ADAMKIEWICZ Maciej: 30 lat Centrum Kształcenia Ustawicznego w Ciechanowie 1979-2009. Ciechanów 2009 CKU; Tow. Miłośn. Ziemi Ciechanowskiej ss. 76, il. Centrum Kształcenia Ustawicznego.

466. BILEWICZ Aleksandra: Uniwersytet Trzeciego Wieku we Wrocławiu w latach 1976-2007. Kraków 2009 Impuls ss. 86, nlb. 2, il.

467. JANIK-KOMAR Joanna: Konferencja naukowa na temat „Uniwersytet ludowy w kszta1towaniu środowiska lokalnego. Konteksty historyczne i teraźniejszość”. Biuletyn Historii Wychowania. [Nr] 24: 2008 [dr.:] 2009 s. 253-254.

Błotnica Strzelecka, 5-6 VI 2008 r.

468. JANIK-KOMAR J.: Uniwersytet Ludowy w Błotnicy Strzeleckiej w latach 1946-1998. Opole 2008 Wydaw. Uniw. Opolskiego ss. 180, il. Uniw. Opolski. (Studia i Monografie; nr 409). 
469. KWIECIŃSKI Zbigniew: Skutki poziomu wczesnej alfabetyzacji w dorosłości. Ars Educandi. T. 5: 2008 s. 205-217, sum.

470. SCHLENDER Grażyna: Towarzystwo Kursów Popularnych im. Adama Asnyka w Kaliszu. Kronika Wielkopolski. 2006 nr 4 s. 68-79, il.

W 1. 1906-1926.

471. TECHMAŃSKA Barbara: Oświata dorosłych i pracujących jako wsparcie dla procesów uprzemysłowienia - na przykładzie LGOM [Legnicko-Głogowskiego Okręgu Miedziowego]. [W:] Między zacofaniem a modernizacją. Społeczno-gospodarcze problemy ziem polskich na przestrzeni wieków. Wrocławskie Spotkania z Historią Gospodarczą, spotkanie IV. Pod red. Elżbiety Kościk, Tomasza Głowińskiego. Wrocław 2009 s. 533-544.

\section{Biblioteki}

472. DZIENIAKOWSKA Jolanta: Państwowe biblioteki dla nauczycieli w Drugiej Rzeczypospolitej. Studium historyczno-bibliologiczne. Kielce 2009 Wydaw. Uniw. Humanist.-Przyrodniczego Jana Kochanowskiego ss. 467, il., sum., res.

Rec.: Uljasz Adrian, Przeglad Biblioteczny. R. 77: 2009 z. 4 s. 532-535.

473. GULIŃSKA Grażyna: Biblioteki szkolne w województwie kieleckim w latach 1944-1956 w świetle polityki kulturalnej państwa. Studia Bibliologiczne Uniwersytetu Humanistyczno-Przyrodniczego J. Kochanowskiego. T. 11: 2008 s. 33-43, sum.

474. JUŚKO Edmund: Biblioteki w szkołach powszechnych powiatu tarnowskiego w okresie międzywojennym. Rocznik Tarnowski. [T.] 13: 2008 s. 113-118.

\section{Dzieje ruchu nauczycielskiego}

\section{Opracowania ogólne i monografie}

475. CHÓR Związku Nauczycielstwa Polskiego „Cantus” w Rzeszowie 1964-2009. Jubileusz 45-lecia. Pod red. Józefa Kawałka. Rzeszów 2009 AWR Atrium ss. 234, tabl. 2, il.

476. CZACHAROWSKA Małgorzata: Związek Nauczycielstwa Polskiego w powiecie grójeckim od momentu powstania do dziś. Grójec-Radom 2009 Nakł. Oddz. Pow. ZNP; Wydaw. Nauk. Inst. Technologii Eksploatacji -PIB ss. 68, il.

Po 1945 r.

477. CZAS jak rzeka. Działania Oddziału ZNP w Gostyninie 2006-2009. Pod red. Stanisławy Składzińskiej. Płock-Gostynin 2009 Wydaw. Korepetytor Marian Gałczyński; ZNP. Oddz. ss. 175, il. ZNP. Oddz. w Gostyninie.

478. DZIWOKI Julia: Z dziejów organizacji zawodowych nauczycieli górnośląskich na przykładzie Królewskiej Huty (Chorzowa) w latach 1922-1939. Zeszyty Chorzowskie. T. 9: 2008 s. $129-153$, Zsfg. 
479. WÓJCIK Henryk: Historia Związku Nauczycielstwa Polskiego w powiecie łęczyckim 1905-2005. Notatki Ptockie. [R. 50]: 2005 [nr] 4 s. 32-42.

480. ZWIĄZEK Nauczycielstwa Polskiego 1905-2005. Notatki Płockie. [R. 50]: 2005 [nr] 3 s. $3-55$.

Treść: Kapturowska Zofia: Jubileusz 100-lecia Związku Nauczycielstwa Polskiego s. 3-4; Bodal Tomasz: Zarys historii Związku Nauczycielstwa Polskiego w Płocku w latach 1905-1965 s. 5-7; Balcerzak Elżbieta: Z działalności Związku Nauczycielstwa Polskiego w Płocku w latach 1965-2005 s. 8-12; Balcerzak Elżbieta: Płockie szkolnictwo w okresie międzywojennym s. 13-14; Czaplicka Janina: Z dziejów Tajnej Organizacji Nauczycielskiej (TON) w latach 1939-1945 s. 15-18; Kurpiewski Tadeusz: Z płockich dziejów ZNP i oświaty w latach 1945-1952 (wybrane zagadnienia) s. 19-23; Szumański Jan: ZNP i oświata w rejonie płockim w latach 1956-1981 s. 24-33; Tomaszewska Bożenna: Reaktywowanie ZNP po okresie stanu wojennego s. 34-42; Choczyński Marian: Wybrane problemy z działalności Związku Nauczycielstwa Polskiego na rzecz oświaty płockiej w okresie transformacji 1989-2005 s. 43-55.

\section{Pamiętniki nauczycieli}

481. CZAJOWA Zofia: Wspomnienia. Warszawa 2007 Tow. Przyj. Warszawy. Oddz. Grochów ss. 254, il.

Nauczycielka, żyła w 1. 1900-1994.

482. GORCZYCA Wojciech: Pamiętnik nauczyciela 1921 (1966)-1989. Cz. 1. Bielsko-Biała 2009 Wydaw. Akad. Techn.-Humanist. ss. 101, il. Akad. Techn.-Humanist. w Bielsku-Białej.

Wspomnienia wrocławskiego nauczyciela z okresu PRL; zawiera też informacje o wcześniejszych losach rodziny.

483. JĘDRAŚ Stanisław: Wspomnienia z życia wielkopolskiego nauczyciela. Leszno 2009 Nakł. aut. ss. 160, il. (Z Kagankiem Oświaty).

Aut. ur. 1925.

484. MAKOWSKI Ryszard: Za murami poprawczaka. Refleksje i wspomnienia. Warszawa 2009 Łośgraf ss. 354, nlb. 6.

Wspomnienia pedagoga z pracy w Zakładzie Poprawczym i Schronisku dla Nieletnich w Laskowcu.

485. MOJA szkoła... Wspomnienia nauczycieli Chełmszczyzny. Praca zbior. pod red. Piotra Mazura. Chełm 2009 PWSZ ss. 153, il. Państ. Wyższa Szkoła Zawodowa w Chełmie.

Antologia wspomnień z okresu PRL.

486. PAMIĘTNIKI i wspomnienia osadników rejonu gminy Grębocice. (Z. 1). Wybór i oprac. Marek Robert Górniak. Głogów 2006 Graf Reklama ss. 46, il. Urząd Gm. w Grębocicach.

Toż. (Z. 2): Powojenne relacje nauczycieli i absolwentów szkół z terenu gminy. Wybór i oprac. M. R. Górniak. Głogów 2008 ss. 150, il. Urząd Gm. w Grębocicach, Gminna Bibl. Publ. w Grębocicach.

487. RADZIWIŁŁ Anna: Moja oświata. Relację nagrała i podała do dr. Katarzyna SolkaDąbrowska. Karta. [Nr] 58: 2009 s. 94-99.

Wspomnienia nauczycielki (1939-2009) z pracy w Warszawie.

488. WOJCIECHOWICZ Antoni: Znad Niemna do Wilna. Iš Panemunès i Vilniu. Tł. na jęz. lit. Algis Uzdila. Gajewo 2009 Drukarnia Apla ss. 244, il.

Wspomnienia nauczyciela ur. 1927; tekst równol. pol., lit. 
489. ZDEB Agnieszka: Wspomnienia (niepokornej nauczycielki). [Wyd.] Zygmunt Szych. Rocznik Tarnowski. [T.] 10: 2005/2006 [dr.:] 2006 s. 201-235.

Z 1. 1932-1990.

\title{
VII. Organizacje młodzieżowe
}

\author{
Harcerstwo
}

490. BŁĘKITNA jedynka żeglarska. Drużyna Harcerska im. Romualda Traugutta w Wilnie. Na podstawie zachowanych kronik i notatek oraz wspomnień pisanych i rozmów zebr. i oprac. Stanisław Słupkiewicz. Warszawa 2009 Studio Edytor ss. 255, nlb. 1, il.

491. BÖHM Tadeusz: Od skautingu do Harcerskiego Pogotowia Wojennego w Wielkopolsce (1912-1945). Wojskowość w działalności harcerstwa wielkopolskiego. Poznań 2009 Media-Expo Wawrzyniec Wierzejewski ss. 166, nlb. 1, tabl. 25, il.

492. [DOKUMENTY do dziejów harcerstwa polskiego z lat 1946-1995]. Rocznik Historii Harcerstwa. [T.] 5: 2009 s. 155-170.

493. DROZD Edward: Czuwaj. Harcerstwo w Muszynie. Almanach Muszyny.[R. 19]: 2009 s. $213-221$.

W 1. 1930-1950.

494. [DZIESIĄTY] X Młodzieżowy Krąg Instruktorski „Szefczyki” im. Janka Bytnara „Rudego”. Rocznik Historii Harcerstwa. [T.] 5: 2009 s. 143-152.

Od 1966 r.

495. FALKOWSKI Wiesław: Historia Hufca ZHP w Bielsku Podlaskim 1919-2009. Bielsk Podlaski 2009 Komenda Hufca ZHP ss. 289, nlb. 1, il.

496. GŁOWACKA-SOBIECH Edyta: W roku 2008 o Tadeuszu Strumille (1880-1958) i Aleksandrze Kamińskim (1903-1978) w rocznicę Ich śmierci. Biuletyn Historii Wychowania. [Nr] 24: 2008 [dr.:] 2009 s. 129-133, sum.

497. GNAT-WIETESKA Zbigniew: Z dziejów konspiracyjnego harcerstwa - kompania Szarych Szeregów Obwodu Armii Krajowej „Mewa” - Mińsk Mazowiecki. Rocznik Mińskomazowiecki. Z. 17: 2009 s. 114-132.

498. HARCERSKI czyn niepodległościowy 1910-1921. T. 3: Wybitni instruktorzy i działacze harcerscy z lat 1911-1939 - współtwórcy niepodległej Rzeczypospolitej. Pod red. Tomasza Katafiasza. Łysomice 2008 Europejskie Centrum Edukacyjne ss. 212, il.

Materiały z III Sympozjum Historyków Harcerskiego Czynu Niepodległościowego, Słupsk 17 X 2001 r.

Treść: Katafiasz T.: Wybitni instruktorzy i działacze harcerscy z lat 1911-1939 w służbie dla Niepodległej (szkic do portretu zbiorowego) s. 17-50; Karwat Janusz: Harcerki wielkopolskie 1912-1939 s. 51-59; Polak Bogusław: Harcerskie rodowody generałów Drugiej Rzeczypospolitej (wybrane przykłady) s. 60-70; BończaBystrzycki Lech: Działalność niepodległościowa i harcerstwo w posłudze biskupa Władysława Bandurskiego s. 71-77; Karwat Janusz: Harcmistrz Rzeczypospolitej Tadeusz Strumiłło (1884-1958) s. 78-85; Massalski Adam, Rembalski Andrzej: Edmund Massalski harcmistrz, pedagog, twórca kieleckiego środowiska naukowego s. 86-99; Wierzejewski Bogdan: Wincenty Wierzejewski - zarys biografii s. 100-110; Handke Waldemar: Stefan Rowecki - skauting na drodze do Legionów Polskich s. 111-119; Dąbrowski Stanisław: Płk Emil Czapliński - Harcerz Rzeczypospolitej, działacz harcerski, kawaler Krzyża Virtuti Militari s. 120-128; 
Wojtyczka Janusz: Eugeniusz Fik (1906-1985) s. 129-139; Dobroński Adam: Harcmistrz Wiktor Szyryński s. 140-147; Durczewski Jaromir: „Być człowiekiem to wciąż przezwyciężać siebie”. Harcerska droga ks. phm. Stefana Wincentego Frelichowskiego s. 148-163; Kościański Zdzisław: Kościańska „Rezerwa Skautowa” w Powstaniu Wielkopolskim 1918/1919 - historia i tradycja s. 164-169; Handke Krzysztof: 7. Drużyna Harcerska im. Henryka Dąbrowskiego przy Rodzinie Kolejowej w Lesznie i Tajna Siódemka 1935-1945 s. 170-178; Wiśniewski Waldemar: Metoda skautowa jako sposób kształtowania postaw obywatelskich s. 179-184; Ilustracje s. 185-197; Aneksy s. 201-212.

499. HAUSNER Wojciech, Kapusta Marcin: Harcerstwo duchowej niepodległości. Duszpasterstwo harcerskie w dokumentach Służby Bezpieczeństwa i archiwaliach środowisk harcerskich 1983-1989. Kraków 2009 Societas Vistulana ss. 350, nlb. 1, tabl. 4, il. + CD. IPN KŚZpNP.

Zawiera też dokumenty.

500. HISTORIA harcerstwa wielkopolskiego. T. 3: Działalność konspiracyjna harcerstwa wielkopolskiego w latach 1939-1945. Praca zbior. pod red. Mariana Pietrzykowskiego. Poznań 2009 Komisja Hist. Chorągwi Wielkopol. ZHP ss. 237, tabl. 1, il. Zw. Harcerstwa Pol. Choraggiew Wielkopolska. Komisja Hist., Zw. Harcerstwa Pol. Komenda Chorągwi Wielkopolskiej im. Powstańców Wielkopolskich 1918/1919. (Wydawnictwo Komisji Historycznej. Ser. 1. Monografie; 23).

Treść: Pilarczyk Zbigniew: Wstęp s. 9-10; Zasady działania organizacji harcerskiej w przeddzień okupacji niemieckiej: Pilarczyk Z.: Ogólna charakterystyka środowiska działania s. 11-15; Pilarczyk Z.: Ogólna sytuacja w harcerstwie w 1939 roku s. 16-18; Böhm Tadeusz: Harcerskie Pogotowie Wojenne s. 19-31; Szare Szeregi w Wielkopolsce: Kozik Tomasz: Struktura organizacyjna i liczebność harcerstwa wielkopolskiego s. 31-33; Kozik T.: Działalność instytucji ponad hufcowych s. 34-36; Pietrzykowski M.: Ośrodki Szarych Szeregów s. 37-138; Inne związki i jednostki: Serwański Edward: Harcerstwo Akademickie s. 139-144; Kozik T.: Hufce Polskie s. 144-145; Nowak Antoni: Komisja Dostaw Harcerskich KaDeHa s. 145-150; Kozik T.: Duszpasterstwo s. 150-151; Pietrzykowski M.: Harcerze w walkach poza Wielkopolską s. 151-154; Aneksy s. $155-212$.

Aut. T. 1. M. Pietrzykowski. Poznań 2004.

501. KAWSKI Tomasz: O żydowskim skautingu, kibucach i produktywizacji w II Rzeczypospolitej uwag kilka. [W:] Ludzie, idee, wojny. Studia z dziejów Europy Środkowowschodniej. Księga pamiątkowa z okazji 70. rocznicy urodzin profesora Włodzimierza Jastrzębskiego. Red. Tomasz Kawski, Jacek Maciejewski. Bydgoszcz 2009 s. 231-242.

502. KOZIMALA Irena: Polski skauting męski w Galicji Wschodniej w latach 1911-1920. Kraków 2009 Komisja Hist. Krakowskiej Chorągwi ZHP ss. 152, tabl. 11, il.

503. KRZANOWSKI Adam, Bogacz Henryk, Mika Wacław: Idea harcerska Andrzeja i Olgi Małkowskich. Korczyna-Krosno 2009 Krośnieńska Oficyna Wydawnicza ss. 32, tabl. 20, il.

504. KURAL Zygmunt, pseud. Orlik, Korczyc: Z Korca do Krakowa. Wołyniak w krakowskiej konspiracji harcerskiej. Oprac. Filip Musiał. Zeszyty Historyczne WiN-u. R. 18: 2009 nr 30 s. 141-180.

Wspomnienia.

505. LITNER Anna: Niepokorni skauci z Kluczborka... O historii Związku Harcerstwa Rzeczypospolitej na ziemi kluczborskiej... Współpr. Piotr Rewienko, Mateusz Fila. Kluczbork 2007 Drukarnia i Wydaw. Antykwa ss. 91, nlb. 1, il. ZHP. Zarząd Obwodu Kluczborskiego, Kluczborski Hufiec Harcerek „Watra”, Kluczborski Hufiec Harcerzy „Płomień”.

XX w.

506. MAŁKOWSKI Kazimierz: Drużyny harcerskie w budynku szkolnym przy ul. Morskiej 79 (1945-1949). Rocznik Gdyński. Nr 20: 2008 s. 132-138.

W Gdyni. 
507. MAŁSZYCKI Dariusz: Harcerstwo w Gdyni w latach 1945-1950. Rocznik Gdyński. Nr 21: 2009 s. 122-149.

508. MAŁYSZKO Andrzej: Proporczyk. Karta. [Nr] 60: 2009 s. 126-127.

Organizowanie skautingu polskiego w miasteczku Romny na Ukrainie w 1917 r.

509. MAZURKIEWICZ Mirosław: W blasku harcerskich ognisk. Opowieść o dziejach harcerstwa Chorągwi Radomskiej. Radom 2009 Społ. Kom. Ratowania Zabytków Radomia ss. 557, il.

XX w.

510. MIERZWIŃSKI Zbigniew: „Wszystko co nasze Polsce oddamy...” Szkice z dziejów skautingu i harcerstwa polskiego. Warszawa 2009 Muzeum Niepodległości ss. 135, nlb. 1, il. (Patriotyzm Wczoraj i Dziś; t. 1).

I poł. $\mathrm{XX}$ w.

511. MURANYI Roman, Węgrzynowicz Jacek: Krajowa Narada Działaczy Harcerskich w Łodzi uznana później za I Zjazd Związku Harcerstwa Polskiego. (Cz. 2). Rocznik Historii Harcerstwa. [T.] 5: 2009 s. 19-39.

Łódź, 8 XII 1956 r.; Cz. 1 pt. Przed Zjazdem Łódzkim. Tamże. [T.] 4: 2008.

512. OSSOWSKA Katarzyna: O pozyskanie dla harcerstwa pomieszczeń w gmachach poszpitalnych na Wawelu. Kartka z dziejów harcerstwa krakowskiego w dwudziestoleciu międzywojennym. Krakowski Rocznik Historii Harcerstwa. T. 5: 2009 s. 22-34.

Zawiera też dokumenty z $1.1925-1926$.

513. PASZYŃSKI Zdzisław: Epitafia harcerzy Hufca Związku Harcerstwa Polskiego im. Czesławy „Baśki” Puzon w Jarosławiu poległych podczas II wojny światowej w latach 1939-1945. Rzeszów 2009 Podkarpacki Inst. Książki i Marketingu ss. 109, nlb. 3, il.

514. ROK 1989 w dokumentach Służby Bezpieczeństwa. Oprac. Marcin Kapusta, Maria Konieczna. Krakowski Rocznik Historii Harcerstwa. T. 5: 2009 s. 70-83.

Dot. Związku Harcerstwa Rzeczypospolitej.

515. RUMIANEK Stanisław Tadeusz: Harcerstwo w Brwinowie 1918-1944. Brwinów 2009 Tow. Przyj. Brwinowa; Samorząd Gm. Brwinów ss. 84, il. (Brwinowskie Zeszyty Historyczne Towarzystwa Przyjaciół Brwinowa; 1/2009).

516. RYBLEWSKA-MAREWICZ Katarzyna: Harcerskie drużyny i gromady kolejowe. Krakowski Rocznik Historii Harcerstwa. T. 5: 2009 s. 21-23.

Lata 1932-1937.

517. RYTEL Agnieszka: Odrodzenie Związku Harcerstwa Polskiego w Łodzi po II wojnie światowej. [W:] Rok 1945 w Łodzi. Studia i szkice. Pod red. Joanny Żelazko. Łódź 2008 s. 275-313.

518. SEMKÓW Piotr: „ZEWIE”. Pismo harcerzy polskich z Wolnego Miasta Gdańska (1935-1938). Rocznik Historii Harcerstwa. [T.] 5: 2009 s. 11-17.

519. SOLIŃSKI Krystian: Harcerska konspiracja. Geneza, powstanie i działalność Harcerskiej Organizacji Podziemnej „Iskra” 1949-1950. Olsztyn 2006 Komenda Chorągwi WarmińskoMazurskiej ZHP im. Grunwaldu ss. 202, il.

Rec.: Tomkiewicz Ryszard, Komunikaty Mazursko-Warmińskie. [R. 50]: 2006 nr 4 s. 570-572.

520. STASIAK Michał: XV Łódzka Drużyna Harcerzy im. Andrzeja Małkowskiego 1945-1950. Krakowski Rocznik Historii Harcerstwa. T. 5: 2009 s. 139-146. 
521. STUDIA z dziejów harcerstwa 1944-1989. Pod red. Marka Wierzbickiego. Warszawa 2009 IPN - KŚZpNP ss. 247, nlb. 1. IPN - KŚZpNP. (Studia i Materiały; t. 15).

Z treści: Wierzbicki M.: Wstęp s. 7-10; [Cz.] 1. Studia i artykuły: Kapusta Marcin: Inwigilacja krakowskiego środowiska harcerskiego przez aparat bezpieczeństwa w latach 1945-1956. Rekonesans badawczy s. 13-37; Hausner Wojciech: Działalność krakowskich drużyn harcerskich na tle ideowych, politycznych, metodyczno-programowych i organizacyjnych decyzji władz naczelnych Związku Harcerstwa Polskiego w latach 1956-1980 s. 38-76; Baran Adam F.: Geneza Porozumienia KIHAM. Jak powstało Porozumienie Instruktorów Harcerskich im. Andrzeja Małkowskiego (25-26 października 1980 r.) s. 77-96; Pamzo Tadeusz: „Dumnie nosi czarne chusty..." IV Zambrowska Drużyna Harcerzy im. Andrzeja Małkowskiego w latach 1984-1993 s. 97-112; Materiały do bibliografii niezależnych czasopism harcerskich 1980-1989. [Oprac.] Jarosław Kowalski s. 113-127; [Cz.] 2. Wspomnienia i relacje: Glass Andrzej: Niepokorni harcerze lotniczy (1957-1965) s. 131-136; Sikorski Tomasz: Mój 11 listopada 1979 roku s. 137-145; Bojko Krzysztof: Biała Służba w 1983 i 1987 r. (fragmenty dziennika) s. 146-164; [Cz.] 3. Dokumenty: Sprawozdanie z działalności Harcerek dawnej Chorągwi Lubelskiej w latach 1944-1979. [Wyd.] Monika Sidor; przy współpr. Zenobii Kitówny s. 167-179; ZHP i „papieska służba”? [Wyd.] Kazimierz Wiatr s. 180-194; [Cz.] 5. Varia: Kuświk Bartosz: Historia jednej organizacji. Organizacja Bi-Pi, Buk 1950 s. 207-210; Hausner W.: Anatomia osaczania s. 218-222; Czopowicz Stanisław: O Radzie Porozumienia KIHAM i odradzaniu się ruchu harcerskiego (1980-1985). Przyczynek metahistoryczny z pogranicza egzystencji i metody s. 223-233.

522. ŚLIWERSKI Bogusław: Przyrzeczenie harcerskie. Historia, metodyka, manipulacje. Kraków 2009 Impuls ss. 244, il.

523. TRZECIA Męska Drużyna Harcerska im. Jana Kilińskiego przy Państwowym Gimnazjum i Liceum Mechanicznym w Chełmie. Chełm 2008 Ryszard Dudziński ss. 51, il.

XX w.

524. WALCZUK Artur: Zarys dziejów polskiego skautingu i harcerstwa na Ziemi Cieszyńskiej (do II. wojny światowej). Zaranie Ślaskie. R. 62: 2005 nr 10 s. 17-24, Zsfg.

Od $1912 \mathrm{r}$.

525. WELKLER Lesław J.: Trzy „czarne szóstki” 1919-1945-1957. Historia Drużyn im. Zawiszy Czarnego w Toruniu. Torun 2007 Nakł. aut. ss. 65, nlb. 2, il.

526. WIŚNIEWSKA Maria: Rola harcerstwa na ziemiach polskich podczas okupacji hitlerowskiej 1939-1945. Rocznik Historii Harcerstwa. [T.] 5: 2009 s. 51-61.

527. WULTAŃSKI Jerzy: Skauting i harcerstwo w Brodnicy w latach 1914-1950. Rocznik Historii Harcerstwa. [T.] 5: 2009 s. 41-50.

528. Z DZIEJÓW „Czarnej Trzynastki”. T. 2: Wspominki trzynastackie. Oprac. red. Michał Najgrakowski. Poznań 2009 Media-Expo Wawrzyniec Wierzejewski ss. 209, il.

Toż. T. 3: Kroniki obozowe 1923-1925. Oprac. red. M. Najgrakowski. Poznań 2009 ss. 115, il.

529. ZARYS dziejów wielkopolskiego harcerstwa akademickiego. Praca zbior. pod red. Wojciecha Kossowskiego i Tomasza Kozika. Poznań 2008 Komisja Hist. Chorągwi Wielkopolskiej ZHP ss. 459, il., rés., rez., sum., Zsfg.

530. ŻYCHOWSKA Maria: Udział Harcerstwa Ziemi Tarnowskiej w walkach o wyzwolenie Polski w latach 1914-1921 (obszar byłego województwa tarnowskiego). Rocznik Tarnowski. [T.] 14: 2009 s. $21-32$. 
Inne

531. BARTKOWIAK Przemysław: Działalność nielegalnych organizacji młodzieżowych w latach 1945-1956 na terenie Żar. Studia Zachodnie. Nr 11: 2009 s. 89-100, sum.

532. BAZIUR Grzegorz: Działalność i likwidacja Związku Walczącej Młodzieży Polskiej „Wolność i Sprawiedliwość” w Krakowie w latach 1950-1952. Sowiniec. Nr 31: 2007 s. 87-107.

533. BESZCZYŃSKA Joanna: Wychowanie dziewcząt w Związku Dziewcząt Niemieckich (BDM) na przykładzie Górnego Śląska. [W:] Po obu brzegach rzeki. Praca zbior. pod red. Janusza Mokrosza. Rybnik-Katowice 2009 s. 127-145.

534. BŁASZCZYK Krzysztof: Niezależne Zrzeszenie Studentów w Wyższej Szkole Pedagogicznej w Zielonej Górze po wprowadzeniu stanu wojennego. [W:] Z dziejów Ziemi Lubuskiej po drugiej wojnie światowej. T. 2: Stan wojenny na Ziemi Lubuskiej. Red. nauk. Czesław Osękowski, Robert Skobelski. Zielona Góra 2009 s. 137-143.

535. GUZEWICZ Wojciech: Stowarzyszenie Młodzieży Polskiej w międzywojennej diecezji łomżyńskiej. Saeculum Christianum. R. 11: 2004 nr 2 [dr.:] 2005 s. 63-100, Zsfg.

536. HISTORIA Koła Leśników 1919-2009. Pod red. Jarosława Szabana. Bedoń 2009 Pol. Tow. Leśne. Oddz. Wielkopolski ss. 264, il.

Z treści: Hymn leśników poznańskich s. 6; Zarys dziejów Koła Leśników Studentów Uniwersytetu Poznańskiego. Lata 1919-1939 s. 7-40; Dzieje Koła Leśników Studentów Uniwersytetu Poznańskiego. Lata 1939-1945 s. 41-48; Dzieje Koła Leśników Studentów Uniwersytetu Poznańskiego. Lata 1945-1950 s. 49-61; Lata 1950-1956 s. 62-63; Dzieje Koła Naukowego Leśników Studentów Wyższej Szkoły Rolniczej w Poznaniu. Lata 1957-1972 s. 64-90; Dzieje Koła Naukowego Leśników Studentów Akademii Rolniczej w Poznaniu. Lata 1972-2008 s. 91-171; Wspomnień czar s. 177-240; Załączniki s. 241-246.

535. NIEZAPOMNIANE wczoraj. 1957-1976. Praca zbior. pod red. Wojciecha Borsuka. Warszawa 2009 MHPRL ss. 447, il. MHPRL.

Antologia wspomnień o Związku Młodzieży Wiejskiej.

538. PRANDOTA Wiktor: „Wici” w płomieniach. Wspomnienia z lat 1944-1972. Warszawa 2007 Fund. Pro Publico Bono ss. 183, il.

Wspomnienia o Związku Młodzieży Wiejskiej „Wici”.

Rec.: Kołodziejczyk Arkadiusz, Rocznik Wołomiński. T. 5: 2009 s. 401-404.

539. PUSZKA Alicja: Sodalicje mariańskie uczniów szkół średnich Krakowa w XIX wieku i w okresie II Rzeczpospolitej. Roczniki Humanistyczne. T. 57: 2009 z. 2 s. 121-158, sum.

540. SADOWSKA Joanna: Młodzież a stalinizm - losy Związku Młodzieży Polskiej na Białostocczyźnie. [W:] Polska północno-wschodnia w okresie stalinizmu. Spojrzenie z perspektywy półwiecza. Pod red. Krzysztofa Sychowicza, Emilii Świętochowskiej-Bobowik, Waldemara F. Wilczewskiego. Białystok-Warszawa 2009 s. 94-102.

541. SĘKOWSKI Paweł: Działalność oświatowo-wychowawcza socjalistów w ramach Organizacji Młodzieży TUR i Związku Niezależnej Młodzieży Socjalistycznej w Krakowie w latach 1945-1948. Annales Universitatis Paedagogicae Cracoviensis. Folia 66: Studia Historica. [T.] 8: 2009 s. 239-252.

542. SIEDZIAKO Michał: Niezależne Zrzeszenie Studentów w Szczecinie w latach 1980-1981. Kronika Szczecina. T. 25: 2006 [dr.:] 2007 s. 107-116. 
543. WOŁOSZYN Jacek Witold: „Walczyć o dusze młodzieży”. Zmagania Związku Młodzieży Polskiej z Kościołem katolickim na Lubelszczyźnie 1948-1957. Lublin 2009 IPN - KŚZpNP. Oddz. ss. 325, nlb. 1. IPN - KŚZpNP. Oddz. w Lublinie. 
